\title{
Prophetic Eyes: \\ The Theatricality of Mark Hitchcock's Apocalyptic Geopolitics
}

\author{
By Tristan Sturm, B.A. (Hons.)
}

\author{
A thesis submitted to: \\ The Faculty of Graduate Studies and Research \\ In partial fulfilment of the \\ requirements for the degree
}

\begin{abstract}
Masters of Arts
Department of Geography and Environmental Studies

Carleton University
\end{abstract}




$\begin{array}{ll}\begin{array}{l}\text { Library and } \\ \text { Archives Canada }\end{array} & \begin{array}{l}\text { Bibliothèque et } \\ \text { Archives Canada }\end{array} \\ \begin{array}{l}\text { Published Heritage } \\ \text { Branch }\end{array} & \begin{array}{l}\text { Direction du } \\ \text { Patrimoine de l'édition }\end{array} \\ \begin{array}{l}\text { 395 Wellington Street } \\ \text { Ottawa ON K1A ON4 }\end{array} & \begin{array}{l}\text { 395, rue Wellington } \\ \text { Ottawa ON K1A ON4 } \\ \text { Canada }\end{array}\end{array}$

Your file Votre référence ISBN: 978-0-494-16445-7 Our file Notre référence ISBN: 978-0-494-16445-7

NOTICE:

The author has granted a nonexclusive license allowing Library and Archives Canada to reproduce, publish, archive, preserve, conserve, communicate to the public by telecommunication or on the Internet, loan, distribute and sell theses worldwide, for commercial or noncommercial purposes, in microform, paper, electronic and/or any other formats.

The author retains copyright ownership and moral rights in this thesis. Neither the thesis nor substantial extracts from it may be printed or otherwise reproduced without the author's permission.
AVIS:

L'auteur a accordé une licence non exclusive permettant à la Bibliothèque et Archives Canada de reproduire, publier, archiver, sauvegarder, conserver, transmettre au public par télécommunication ou par l'Internet, prêter, distribuer et vendre des thèses partout dans le monde, à des fins commerciales ou autres, sur support microforme, papier, électronique et/ou autres formats.

L'auteur conserve la propriété du droit d'auteur et des droits moraux qui protège cette thèse. $\mathrm{Ni}$ la thèse ni des extraits substantiels de celle-ci ne doivent être imprimés ou autrement reproduits sans son autorisation.
In compliance with the Canadian

Privacy Act some supporting forms may have been removed from this thesis.

While these forms may be included in the document page count, their removal does not represent any loss of content from the thesis.
Conformément à la loi canadienne sur la protection de la vie privée, quelques formulaires secondaires ont été enlevés de cette thèse.

Bien que ces formulaires aient inclus dans la pagination, il n'y aura aucun contenu manquant.

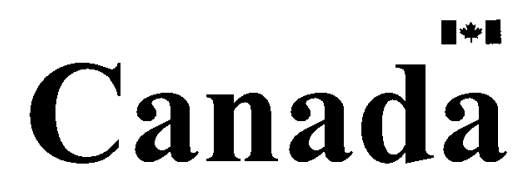




\section{$\underline{\text { Abstract }}$}

Geopolitical analysis has left religion in the margins and footnotes of its scholarship. This thesis will help rectify this shortcoming. Evangelist Mark Hitchcock and his prophetic biblical interpretations have proliferated in the United States, influencing millions of Americans. Hitchcock's exegesis is based on four 'evil' geopolitical containers: the 'Muslim alliance', the 'Roman Empire', Russia, and the 'kings of the Far East'. Through the Rapture and through biblical dictation/interpretation, Hitchcock is able to transcend Earth to write his Apocalyptic geopolitics and qualify the character of the people living in his geopolitical blocs as homogeneous units of evil. This thesis traces the reasoning strategies of how Hitchcock separates himself from the materiality of world politics, claims to 'know the future' through detached, objective, unproblematized theatrical and visual analogies, allowing him to see the world as a whole, and giving him the power to 'know' the Other. 


\section{Acknowledgments}

Various paragraphs written for this thesis were published in the journal Geopolitics (2006) and presented to the American Association of Geographers (AAG) (2006) in Chicago, as 'Prophetic Eyes: The Theatricality of Mark Hitchcock's Premillennial Geopolitics'. This paper also won the David E. Sopher New Scholar Award for best religion paper presented by untenured faculty at the AAG. Sections of another paper presented in London, Ontario to the Canadian Association of Geographers (2005) entitled 'Apocalyptic Geopolitics', are also used throughout this thesis. Furthermore, the paper 'American Political Economy and Apocalyptic Empire', presented to the $6^{\text {th }}$ Annual Graduate Political Economy Conference (2005) at Carleton University, has found space in the conclusion of this thesis. The paper 'Without Geography 'They're' Nowhere: Questions on Utopia and Ives Lacoste' presented to the Canadian Association of Geographers Ontario Division (2004) at the University of Waterloo, helped me formulate ideas on utopia/nowhere and is used in Chapter 5. All of the material written and presented in these forums was originally done so with the intent of thinking through the ideas and texts presented in this thesis.

I would like to thank John Agnew, Andrew Baldwin, David Campbell, John Clarke, Ruby Dumais, Gwilym Eades, Michael Ferber, Leah Gilbert, Fiona Mackenzie, Lori Massini, Nick Megoran, Brandon Schaufele, Anne-Marie Schryer-Roy, and Gearóid Ó Tuathail for reading and commenting on parts of this thesis. Your suggestions and comments were friendly, albeit critical, and useful beyond words. I would like to thank Noel Salmond in the department of Religious Studies for giving me several hours of his 
time to talk through these ideas. Ben Moffat, as always, encouraged and pushed me farther. I owe much of this to him, particularly with respect to my interest in geography. If it wasn't for his always entertaining classes I might today be a wealthy and bored charted general accountant. As well, thanks, Ben, for your detailed comments on this thesis. Certainly my supervisors Simon Dalby and Iain Wallace have been of great help in the many scholarly routes I've taken at Carleton University. Thank you for encouraging me through rough times and for reading terribly written drafts just days before journal deadlines, and certainly for having the patience to read through this thesis. In this respect, thank you for giving me financial support, a thanks that goes to Carleton University, as well. Without funding, I would not have been able to purchase the many prophecy books used to write this thesis. The access to these texts was a burden but was also reaffirming that this research was vastly under studied. Thank you to Mark Hitchcock for being receptive and kind in our many conversations. Without your cooperation this thesis would lack your analysis of this work and an important empirical dimension. I would also like to the thank the two anonymous reviewers who read my Geopolitics paper and the four anonymous reviewers of the David E. Sopher New Scholar Award for detailed critique that helped bring those papers and this thesis to a more professional and cogent level. How could I forget my sanity: thank you Eric Oh and Jay Joshi for having patience, taking me x-country skiing when I should have been working on my thesis and thank you for reading over almost every word I wrote during my Master's. Doug, Karen and Clinton Sturm, my family, thank you for your always available and loving support and encouragement. If I have missed anyone, I am truly apologetic, and I thank you. 
1. Critical and Apocalyptic Geopolitics.

Critical Geopolitics

Apocalyptic Geopolitics

2. Strategies Toward Transcendence: Theory and Method

Performance and Performativity

Method: Discourse, Foucault and Strategy

Transcendence/Transgression, Strategy/Tactic

3. Act 1: The Father's Heavenly Separation

The Theatre of the Apocalypse

Theatre as Strategy: The Only way Out is Up

Hitchcock's Author-itative Power

4. Act 2: Seeing the Whole Picture

Privileging and the Geo: Distancing and Representation

A Short History of Premillennial Geopolitics

Hitchcock and the New Apocalyptic Picture

5. Act 3: Knowing the Evil Other

Othering Strategies: Heaven/Earth, America/Middle East

Othering Between the Border of Heaven and Earth

Othering Between America and the Middle East

Curtain

Bibliography 


\section{List of Figures and Tables}

Figures

1. Four Best-Selling Hitchcock Books (1993-2004)

2. Israel's Prophesied Territory

3. Mark Hitchcock's Place Translations and Four Geopolitical Blocs

4. 'God's Blue Print for the End Times'

5. Ó Tuathail's Geopolitical Diagram

6. The Premillennial Spatial Separation of Responsibility 65

7. Hal Lindsey's Maps of Armageddon 74

8. Early 'T and O' Maps 99

9. Shrieky and Mr. Beastly of the Care Bears 115

10. Charles Dyer and the Arab Mind 125

Table

1. Changing Premillennial Toponyms (1970-2005) 105 


\section{Setting the Scene:}

\section{Premillennialism and Mark Hitchcock}

\section{The 'Politics' of the Apocalyptic 'Geo'}

Prophetic geographical imaginations in the United States have, since the end of the Cold War, undergone a significant conversion, one that sheds light on the political contingencies of an otherwise thought-to-be-predestined Christian premillennial prophecy. Premillennial prophecy restructured its geopolitical imaginations as to where 'evil' lies from the Cold War, when the United States' enemy was believed to be the Communist Soviet Union, to more recent tropes that have relocated the 'evildoers' to the Muslim Middle East. Prophecy is presently focused on what is called the 'Muslim Alliance', otherwise referred to as the 'King of the South'. The 'King of the North' (Rosh, Magog, Gomer, Meshech, Tubal, Beth-togarmah all of which are led by Gog) was to represent Russia and the Soviet Union during the Cold War, but is now states with Muslim majorities. ${ }^{1}$ Mark Hitchcock, though a relatively new prophecy writer, is perhaps best known for this post-Cold War re-orientation of prophecy.

Norman Cohn's classic study of millenarianism (1970) comes to the conclusion that apocalyptic speculations are never free from political content or consequences. ${ }^{2}$ Prophecy, as Boyer explains, is not merely a reflection of other realities: 'apocalyptic cosmologies have functioned dynamically, helping to mould political and social ideology

\footnotetext{
${ }^{1}$ Ezekiel 38 and 39; Daniel 11: 40-45; Joel 2:20.

${ }^{2}$ N. Cohn, The Pursuit of the Millennium: Revolutionary Millenarians and Mystical Antichrists of the Middle Ages (London: Temple Smith, 1970 [Originally published in 1957]).
} 
and thus influencing the course of events'. ${ }^{3}$ Although premillennialists share a belief in fatalism and pessimism, they do take action to change the world in light of their apocalyptic geopolitics, and however idealist, utopian or 'out-of this-world', politics undergrid the whole process. Prophecy expounders only find it necessary to admit that foreign policy has informed their geopolitics when it reinforces their beliefs. The theatres of Afghanistan and Iraq have provided renewed vigour from the rather peaceful Clintonera for what Sharp referred to as the 'spectre of Armageddon' from which to affirm and normalize apocalyptic geopolitics and America's role in it. ${ }^{4}$

Hitchcock's theatrical images of the Rapture-an event when all faithful Christians are summoned into Heaven seven years before the Apocalypse-and Armageddon help shape American (predominantly premillennialist) attitudes; they have encouraged the development of a systematic view of Muslims, Russians, and Europeans and have articulated attitudes toward the Cold War and wars in the Middle East. ${ }^{5}$ These views have literally become geography textbooks for millions of Americans. But their textbooks, in contrast to secular versions, lack alternative geographies. Texts are set in $a$ historical context and influence people and politics both spiritually and materially. ${ }^{6}$ Prophecy texts reduce the Middle East, Asia, Russia, and Africa to evil expanses of territory with little concern for individuals who live there. Making it easy for the reader to

\footnotetext{
${ }^{3}$ P. Boyer, When Time Shall Be No More: Prophecy Belief in Modern American Culture (Cambridge, Mass: Harvard University Press 1992) p78.

${ }^{4}$ See J. Sharp, Condensing the Cold War: Reader's Digest and American Identity. (Minneapolis: University of Minnesota Press, 2000) p.39.

${ }^{5}$ See Ibid. p.39.

${ }^{6}$ Terry Ratzmann, a resident of Brookfield, Wisconsin, is reported to have shot and killed seven church members including the minister at the 'Living Church of God, [after the minister] recently prophesied endtimes were near'. See 'Killer Upset by Sermon: Doom Prophecy Sparked Rampage?' The Ottawa Sun, March 14 (2005).
} 
identify the 'enemy' is a curriculum of 'evangelizing fear" with the intent to acquire followers before the Rapture. Thus, these apocalyptic geopolitics are imagined but are certainly not imaginary.

These apocalyptic imaginations give war new meanings, particularly to military personnel. Prophecy expounders have a history of targeting American soldiers. Hal Lindsey, one of the most prolific and popular prophecy writers of the $20^{\text {th }}$ century, claims to carry copies of his books with the intent to hand them out to military personnel. ${ }^{8}$ In terms of the popularity of prophecy among the military, Lindsey (1980) describes a lecture he gave to the American Air War College, "even though attendance was totally voluntary, virtually the entire school turned out, including many officers accompanied by their wives'. ${ }^{9}$ Hitchcock, through email correspondence with the author on March $13^{\text {th }}$, 2006, wrote on his involvement with the military:

[O]ur church is near Tinker Air Force base, so we have had several officers (including one general) as members of our church. I have corresponded with some military personnel who have read my books and call to either give me information or ask questions. I received several emails, including pictures, from a soldier in Camp Babylon, Iraq who was reading my book The Second Coming of Babylon. ${ }^{10}$

Hitchcock then, has direct influence over military personnel that make decisions concerning war. He helps guide people who engage in combat with the very people Hitchcock vilifies; he helps give the War in/on Iraq prophetic meaning to those who carry guns and more importantly to those officers who order solders to shoot the 'evil' Muslims Hitchcock describes in all of his books; and he helps define the war as a battle between

\footnotetext{
${ }^{7}$ D. Campbell, Writing Security: United States Foreign Policy and the Politics of Identity (Minneapolis: University of Minnesota Press, 1998 [Originally published in 1992]) p.81.

${ }^{8} \mathrm{H}$. Lindsey, The 1980's: Countdown to Armageddon (King Of Prussia, PA: Westgate Press, 1980) pp.4-5.

${ }^{9}$ Ibid.

${ }^{10}$ Email correspondence with Hitchcock on March $13^{\text {th }}$, 2006. His, book The Second Coming of Babylon details the importance of the rebuilding of Babylon, Iraq in the coming apocalypse. See M. Hitchcock, The Second Coming of Babylon (Sisters, Ore: Multnomah Publishers, 2003).
} 
God's and Satan's people. The soldiers that read his books and listen to his sermons then find that the war is not simply in the name of the United States but is also carrying out God's work.

Political elites are no exception to the influence of prophecy: they too are a part of culture. ${ }^{11}$ We should remember Alexis de Tocqueville's famous observation in the $1830 \mathrm{~s}$ that the American religious and political values were so entwined as to be inseparable. ${ }^{12}$ U.S. President Reagan and members of his government have been reported as making apocalyptic and religiously motivated statements. This group includes Interior Secretary designate James Watt, Reagan's Surgeon General C. Everett Koop, and Secretary of Defence Caspar Weinberger, who when asked about prophecy in 1982 replied 'I have read the Book of Revelation and yes, I believe the world is going to end-by an act of God, I hope-but every day I think that time is running out'. ${ }^{13}$ Reagan, a professed premillennialist, actor, and former President of the United States, said in response to Colonel Gaddafi's 1971 coup in Libya:

That's a sign that the day of Armageddon isn't far off...Everything is falling into place. It can't be long now. Ezekiel says that fire and brimstone will be rained upon the enemies of God's people. That must mean that they'll be destroyed by nuclear weapons. ${ }^{14}$

\footnotetext{
${ }^{11}$ J. Sharp, 'Re-maculinizing Geopolitics? Comments on Gearóid Ó Tuathail's Critical Geopolitics', Political Geography 19/3 (2000) p.362.

${ }^{12}$ N. O. Hatch, Sacred Cause of Liberty: Republican Thought and the Millennium in Revolutionary New England (New Haven, Yale University Press, 1977) p. 174.

${ }^{13}$ Boyer, When Time Shall Be No More, p. 141; See also Northcott, An Angel Directs the Storm Apocalyptic Religion and American Empire (London: I.B. Tauris 2004), p.66-68.

${ }^{14}$ Quoted in Boyer, When Time Shall Be No More, p.142. See p.142-143 for more Reagan quotes with a premillennial bent and a discussion of Reagan's beliefs. Whether George W. Bush is a premillennialist is debatable, see M. Northcott, An Angel Directs the Storm, p.67. For contemporary examples of American legislators with premillennial leanings, see Scherer, 'The Godly Must be Crazy'; See also C. Gallaher, 'The Religious Right Reacts to Globalization', in M. A. Tetreault and R. A. Denemark (eds.), Gods, Guns, and Globalization: Religious Radicalism and International Political Economy (Boulder: Lynne Rienner, 2004) pp.32-39.
} 
Furthermore Reagan's role years later in creating the second Cold War through arms build-up as President of the United States cannot be overlooked. ${ }^{15}$ This is not to say that he would have engaged the Soviet Union simply to make prophecy come true, but one should not discount his hyper-(im)moral religious language of 'evil empires', massive military spending and his agreement to spend trillions of dollars on new nuclear weapons; all of which have real, practical and material consequences that appealed to millions of premillennial Americans. Whether Reagan consciously let prophecy interpretation inform his foreign policy is not known, however Reagan's beliefs could have certainly made these decisions much easier. These apocalyptic geopolitics are staunchly entrenched as a belief system for millions of Americans and also offer theological reinforcement to hostile views of Muslims, Russians and Europeans and offer equanimity to the prospect of terrorism or nuclear attack.

Whether President George W. Bush believes in apocalyptic prophecy is unclear. If he does, his speech writer and political advisor, Michael Gerson, has done a good job preventing him from making explicit statements about his Evangelical leanings. When asked on March 20th, 2006 in Cleveland, 'Do you believe this, that the war in Iraq and the rise of terrorism are signs of the Apocalypse?' Bush replied, as transcribed by CNN, 'Hmmm'. Then continued, 'The answer is I haven't really thought of it that way. Here's how I think of it. First, I've heard of that, by the way'. The official White House website transcript alters the punctuation, dropping the strategic comma, and adding 'the', thereby changing the meaning: 'The first I've heard of that, by the way'. Bush then side-steps the question and talks about 9/11. Bush would fall under scrutiny if he had said 'yes' from

\footnotetext{
${ }^{15}$ See S. Dalby, Creating the Second Cold War (New York: Guilford, 1990). See also G. Halsell, Prophecy and Politics: Militant Evangelists on the Road to Nuclear War (Westport, CN: Lawrence Hill, 1986).
} 
the secular side and would have fallen under scrutiny had he said 'no' on the premillennial side. $^{16}$

The idea that Bush has divine endorsement and therefore has a divine mandate suggests that same prophetic attitude Hitchcock uses to transcend critique. If one reads Ron Suskind's (2004) article in New York Times magazine or scans the Presidential Prayer Team website that is riddled with quotes from the Bible like, '[t]hey cried out to Him during the battle. He answered their prayers, because they trusted Him' (I Chronicles 5:20), it is clear that the Christian Right believes Bush is ordained by God. Bush twice told supporters before his 2000 election that he felt God wanted him to run for president. ${ }^{17}$ Whether Bush believes he is God's vicarious Messiah or not really makes little difference in justifying foreign policy. Whether voting Americans do think he is on religious assignment, makes a difference. If citizens of the United States believe Bush to have divine endorsement then can one be critical of his work? Would criticising him be criticising Him? ${ }^{18}$ It was made clear and morally cogent in the third presidential debate that conducting a war in Afghanistan was carrying out God's word: 'I believe that God wants everybody to be free. That's what I Believe. And that's been part of my foreign policy. In Afghanistan, I believe that the freedom there is a gift from the Almighty' ${ }^{19}$

\footnotetext{
${ }^{16}$ On premillennialist apathy toward a struggling American economy because of the coming Rapture, see K. Philips, American Theocracy: The Peril and Politics of Radical Religion, Oil, and Borrowed Money in the 21st Century (New York: Viking, 2006). See also, S. Blumenthal, 'In Bush We Trust', Salon.com March 23, 2006 [www.salon.com/opinion/blumenthal/2006/03/23/bush_terror/index_np.html].

${ }^{17}$ H. A. Giroux, 'Beyond Belief: Religious Fundamentalism and Cultural Politics in the Age of George W. Bush', Cultural Studies. 4/4 (2004) p.416.

${ }^{18}$ Romans 13 makes reference to this: 'Whosoever therefore resisteth the power, resisteth the ordinance of God: and they that resist shall receive to themselves damnation'.

${ }^{19}$ Bush/Kerry debate Oct. 3, 2004.
} 
Religious analysis in geopolitics is contemporarily important because the "new enemies' between the East and West are geo-graphed into religious categories. ${ }^{20}$ With premillennialism's pervading influence in American evangelical Christianity, any analysis of its geopolitical foundations is both timely and relevant considering the influence evangelical Christians have in American politics. ${ }^{21}$ Religion can be seen as one of the key cultural sources in evangelizing Cold War geopolitics: the Communists didn't have a God, but Muslims have the wrong God! 22 'Islamic nations', Hitchcock expounds, 'are so dangerous today'. ${ }^{23}$ The religious cultivation of the 'evil' Other through geographical and visual metaphors is disconcerting because of the assumption that his/His geography is 'natural' and really exists. Furthermore, the premillennial ideology that history is on a steady decline into Satan's hands combined with notions of powerlessness can be seen as a recipe for valorizing violence.

\section{Geography, Geopolitics and the Argument}

The study of religion in geography has been deemed as, 'lacking in coherence...existing in a state of disarray...[and therefore] purportedly attracting few thinkers'. ${ }^{24}$ Prophecy itself has had little attention in geography. ${ }^{25}$ This lack of religious attention could be due

\footnotetext{
${ }^{20}$ By this I mean, for example, Samuel Huntington's religiously based 'civilization' categories, see S. Huntington, The Clash of Civilizations and the Remaking of World Order (New York: Touchstone, 1996).

${ }^{21}$ Boyer, When Time Shall Be No More, pp.141-142; See also Halsell, Prophecy and Politics.

${ }^{22}$ For an example of how religion affected the Cold War and was affected by it, see L. Canipe, 'Under God and Anti-Communist: How the Pledge of Allegiance Got Religion In Cold War America', Journal of Church and Society 45/3 (2003) pp.305-323. See also Northcott, An Angel Directs the Storm, pp.25-35 and D. Kirby, (eds.), Religion and the Cold War (Basingstoke: Palgrave-Macmillan 2003).

${ }^{23}$ Hitchcock, The Coming Islamic Invasion of Israel, p. 18.

${ }^{24}$ L. Kong, 'Mapping “New” Geographies of Religion: Politics and Poetics in Modernity', Progress in Human Geography 25/2 (2001) p.211; on the 'embodiment, performance and practice' of religion in geography see, J. Holloway and O. Valins. 'Editorial: Placing Religion and Spirituality in Geography', Social and Cultural Geography 3/1 (2002) p.7.

${ }^{25}$ See, for example, R. W. Stump, Boundaries of Faith: Geographical Perspectives on Religious Fundamentalism (Lanham, MD: Rowman and Littlefield, 2000); P. J. Taylor, 'Tribulations of Transition',
} 
to the fact that geographers of religion have, for the most part, developed research paradigms 'with a strong empirical basis ${ }^{26}$ emphasizing the 'objective' elements of religion at the expense of those held to be 'subjective'. While these studies have advanced our understandings of the impact religion has had on the cultural landscape, their very object of analysis of religion is treated rather unproblematically. And while it is important for us to acknowledge that 'traditional' geographers of religion have at least asserted that 'religion matters' in geography, many continue to analyze religion within an empiricist framework. In response to the latent positivism and empiricism in 'traditional' geographies of religion, new geographers of religion have been embracing more theoretically informed approaches, 'while remaining extremely competent in dealing with traditional concerns'. ${ }^{27}$ While sympathetic to the aim of the 'new' geographers of religion in striving for more theoretically sophisticated approaches to ground their empirical research, geographies of religion have not made any significant theoretical contributions of their own-despite the fact that religion is a very fertile ground for the development of theory. The theories of theatrum mundi presented below could prove to be fruitful in addressing this shortfall.

Almost a decade ago Gearóid Ó Tuathail in his book Critical Geopolitics wrote that 'there are many connections between geopolitical thought and religious thought (vision,

Professional Geographer 44/1 (1992) pp.10-12; J. M. Curry-Roper, 'Contemporary Christian Eschatologies and Their Relation to Environmental Stewardship', Professional Geographer 42/2 (1990) pp. 157-165; C. Gallaher, 'Identity Politics and the Religious Right: Hiding Hate in the Landscape', Antipode 9/3 (1997) pp.256-277.

${ }^{26}$ R. Stoddard and C. Prorok 'Geography of Religion and Belief Systems', in G. Gaile and C. Willmont (eds) Geography at the Dawn of the $21^{\text {st }}$ Century (Oxford University Press: New York, 2004) p.765. See C. Park, Sacred Worlds: An Introduction to Geography and Religion (Routledge: New York, 1994).

${ }^{27}$ Kong, 'Mapping "New" Geographies of Religion' p.212. See, for example, the special forum in the Annals, of the American Association of Geographers 96/1 (2006) pp.165-202. On theoretical approaches, look for the C. Prorok and M. Ferber (ed.) Doing Geographies of Religion (Thousand Oaks, CA: Sage, forthcoming in 2007) in which the author has a chapter. 
prophecy, father figures, and so on) that deserve investigation'. ${ }^{28}$ Other scholars of geopolitics, including Gertjan Dijkink, have structured a research agenda for this relationship. ${ }^{29}$ Yet, at this point few scholars have actively investigated this relationship. Moreover, of those who have undertaken such research most have limited their analysis to how religion has influenced their scholarship on geopolitics or how academic and state geopoliticians have used religious discourse. ${ }^{30}$ As a 'religion as geopolitics', this thesis hopes to reverse the direction of prior scholarship. 'Religion as geopolitics', a term coined by John Agnew (co-editor of the journal Geopolitics), has 'conditioned the [formal and practical] geopolitical discourse ${ }^{, 31}$ and shows how religion has fabricated its own geopolitical discourse-one laced with a taxonomy of geopolitical thought that has flown under the radar of non-theological criticism. If we are interested in 'making sense' of geopolitics, we must attend to all of its influencing factors such as how it is affected by religion and, reciprocally, how geopolitics has pervaded religion. It is how geopolitics get blurred between porous boundaries of influence that is paramount to understanding the subject.

This thesis stresses the apocalyptic geopolitics of Evangelical author Mark Hitchcock. It is a study of discursive strategies whereby American evangelical reasoning

\footnotetext{
${ }^{28}$ This comment is a sidebar to endnote 38 in G. Ó Tuathail, Critical Geopolitics: The Politics of Writing Global Space (Minneapolis: University of Minnesota Press, 1996) p. 276.

${ }^{29}$ G. Dijkink, 'When Geopolitics and Religion Fuse', presented at the $5^{\text {th }}$ Pan-European International Relations Conference, in The Hague (Sept. 2004) pp.3-6.

${ }^{30}$ G. Ó Tuathail, 'Spiritual Geopolitics: Fr. Edmond Walsh and Jesuit Anti-Communism', in K. Dodds and D. Atkinson (eds.), Geopolitical Traditions: A Century of Geopolitical Thought (London: Routledge, 2000) pp.187-210; L. Nyroos, 'Religeopolitics: Dissent Geopolitics and the "Fundamentalism" of Hamas and Kach', Geopolitics 6/3 (2001) pp.135-157; Dijkink 'When Religion and Geopolitics Fuse' pp.1-13. On how being Christian influences one's scholarship on geopolitics, see N. Megoran, 'Christianity and Political Geography: On Faith and Geopolitical Imagination', The Brandywine Review of Faith and International Affairs, $2 / 2$ (2004) pp.40-46. Scholars in the field of international relations have also studied the relationship between religion and international politics. For predominantly constructivist scholarship, see P. Hatzopoulous and P. Petito (eds.), Religion in International Relations: The Return from Exile (New York: Palgrave Macmillan 2003).

${ }^{31}$ Ó Tuathail, Critical Geopolitics, p.255.
} 
works. It will question the taken-for-granted theatrical geographies Hitchcock imagines, posits, and makes normative by addressing several general questions throughout this thesis: what are Mark Hitchcock's geopolitics? How have the Bible, Formal/Popular/Practical geopolitical representations and apocalyptic theology, made it possible for Mark Hitchcock to interpret and represent deeply political geographies as biblical/holy/Christian prophecies? As a strategy toward apolitical eschatology, how have Hitchcock's theatrical metaphors of Armageddon, the Rapture, and of his ordained societal position removed his geopolitics from a human formulation to that of Christ's? And how have the 'inside' of evangelical circles influenced 'outside' geopolitical constructions and vice-versa? This thesis offers a comparative cultural history of the protean geopolitical boundaries of dispensationalists and their historical relation to American foreign policy and cultural ideology of the world east of Western Europe from 1970 to 2005. It also explores the binary geographies of 'good-Christian' and 'badMuslim'/'evil-Communist' that help legitimate geopolitical constructions of the world that qualify Others on the basis of state or regional borders. A cursory analysis of the geopolitics of other premillennial authors like Tim LaHaye, Hal Lindsey, Charles Dyer and John Walvoord is important in examining the discourse that came before Hitchcock and therefore how he came to write his particular geopolitics. Analysing those antecedents will minimize the distortion of looking at premillennial usage of the theatre metaphor and apocalyptic geopolitics as a vacuum especially when the analysis might appear to be an exceptionalist reading.

This research is not concerned with how premillennialists offer guides to private faith or (inter)personal conduct. Rather, it aims to examine how premillennial theology, 
specifically that represented in the writing of Hitchcock, takes on a geopolitical cast. Nor does this research take as a central issue how state politics has used premillennialism to prop-up policy or legitimate war; it deals almost exclusively with 'religion as geopolitics'. ${ }^{32}$ It concerns itself with how Hitchcock represents the world and adds meaning to it and asks how it is possible to think and legitimate this? And because this thesis focuses on Hitchcock, it in no way claims to be representative of premillennialism as a whole. Geopolitics as portrayed in this thesis, then, is the design of the world where the ideology of Premillennialism and the geographic are politically superimposed.

This thesis is concerned with symbolic orders and their power/knowledge space formations. This thesis interrogates Hitchcock's configurations of power that weaves biblical exegesis with current events for geopolitical content. In other words, it examines how Hitchcock legitimates geopolitics as religious (for example, wars in the Middle East, globalization, the environment, and Russian foreign policy) when they are obviously deeply rooted in political events and decisions. The genealogy of the strategies Hitchcock uses to 'normalize' his discourse is based on all of his published works but focuses on Hitchcock's more geographical writings, specifically on the relation between the End Time and scripture.

The later work of Michel Foucault on 'transcendence/transgression' is used to expose how power is operationalized through Hitchcock's texts as a theoretical guide to bring premillennialism back into historical subjectivity. Overall this thesis is haunted by the work of Foucault though most often indirectly through other philosophers who were influenced by him. Michel de Certeau's work on 'strategies/tactics' is the major point of departure in this thesis from which to unveil the very political theatres Hitchcock hides

\footnotetext{
${ }^{32}$ See special issue of the journal Geopolitics $11 / 2$ (2006).
} 
behind. De Certeau is not used as a reading strategy itself, but rather a theoretical guide to the rather loose method of discourse analysis Foucault alludes to. Similar to Agnew's discussion on 'visualizing global space', 33 this thesis outlines three strategies of geopolitical vision Hitchcock uses to make religious 'truths'. The first problematizes Hitchcock's use of theatrical metaphors to describe his geopolitics-how he uses the Rapture, Bible, and his 'Father' author-ity to separate himself from subjectivity and harm during Armageddon. Working from this transcendence in Heaven from which Hitchcock writes, he is able to write 'grand geopolitical narratives' through what he calls his 'prophetic eyes'. ${ }^{34}$ The last strategy, also stemming from his transcendent position, describes how Hitchcock justifies his End Time violence by envisioning and excluding the 'evil' Other.

\section{The Geopolitics of Mark Hitchcock}

Hitchcock, who has been described as a moderate End Time seer and historian, was selected for this study for four reasons: $:^{35}$ first, he has written over 22 popular books on the subject and hundreds of articles in just over ten years, perhaps more than any other prophecy writer; ${ }^{36}$ second, because he is an admired pastor at Faith Bible Church in Oklahoma and holds a Ph.D. from Dallas Theological Seminary, where other major

\footnotetext{
${ }_{33}^{3}$ J. Agnew, Geopolitics: Re-visioning World Politics (London: Routledge, 1998) pp.11-31.

${ }_{35}^{34}$ Hitchcock, The Second Coming of Babylon, p.10.

${ }^{35}$ For two articles that describe Hitchcock in this manner and interview him, see B. Broadway, 'Direst of Predictions For War in Iraq: End-Time Interpreters See Biblical Prophecies Being Fulfilled', The Washington Post (March 8, 2003) p.B09, and J. Lampton, 'The End of the World', Christian Science Monitor (February 18, 2004).

${ }^{36}$ Hitchcock is also, along with Jenkins and LaHaye, an the editor and major contributor to the Left Behind online journal Interpreting the Signs which has over 20000 monthly subscribers. Hitchcock writes the sections 'America in the End Times', 'Babylon and Other Holy Places', 'Government' and 'Russia and the EU', while Jenkins and LaHaye write in sections of 'Society' and 'Culture'. See [http://secure.agoramedia.com/index_leftbehind.html].
} 
prophecy writers like John Walvoord and Hal Lindsey also obtained degrees, ${ }^{37}$ third, he was one of the first prophecy writers to challenge the Cold War geopolitical order in light of turmoil in the Middle East; and most importantly, though consistent with other major premillennial writers, like Charles Dyer, Tim LaHaye, and Hal Lindsey, Hitchcock carves out his own niche by tackling the geography of the Bible and prognosticates the future of the world based on these interpreted geographies. ${ }^{38}$ When asked what interest in geography he had, Hitchcock replied,

My interest in geography has aided me significantly in my study of prophecy. Bible prophecy involves many different nations and places. Knowing the historical locations of these places and their modern counterparts is indispensable in understanding the outline of end time events and places. ${ }^{39}$

The very word 'sign' for Hitchcock is a spatial road-map to the knowledge of the end of the world. A glance at a selection of his book and journal titles in the notes section below

\footnotetext{
${ }^{37}$ Hitchcock and his Left Behind collaborators are not without premillennial detractors. Other premillennial groups believe America is Babylon in contrast to Hitchcock's thesis that it is Iraq-a thesis reiterated in the Left Behind series-see Iraq Revived As Mystery Babylon? Some Prophecy Interpretations Die a Hard Death: A Book Review of The Second Coming of Babylon by Mark Hitchcock (The Alpha-Omega Report, 2003) [http://aoreport.com/bk-mh-iraq-is-m.b.review.htm]. Furthermore, Tyndale, who publishes the Left Behind series and some of Hitchcock's books, published the book, H. Hanegraaff and S. Brouwer, The Last Disciple (Wheaton, Ill: Tyndale, 2004). Contrary to Left Behind, Hanegraaff and Brouwer explain that many of the prophecies in the Book of Revelation have already happened before the Tribulation period. As a result and after an apparent battle with Tyndale over this eschatological debacle, LaHaye has decided to publish his new fiction series about Iraq's theological significance (titled Babylon Rising) through Random House.

${ }^{38}$ Although Hitchcock has only sold approximately 350000 books on the subject, a number which pales in comparison to the 50 million books sold through the Left Behind series, we must remember that Left Behind is made up of 11 other authors (including Hitchcock) and, furthermore, is predominantly fiction. Because Left Behind is predominantly fiction Hitchcock with Thomas Ice wrote the Left Behind book The Truth Behind Left Behind (Wheaton, Ill: Tyndale, 2004) which both critiques and confirms the prophecy laid out in the fiction series. Hence, Hitchcock acts as the 'scholarly father' of the 'truth'. Hitchcock's work, though very accessible and tabloid like, is not fiction and rather comparatively 'scholarly' and marketed as Biblical supplementation for followers (including American elected officials and policy makers) and also pastors who influence those followers with the power to vastly increase Hitchcock's readership, albeit indirectly, in formal church functions. (Hitchcock's book sales is an estimated figure from correspondence with Hitchcock on August 15, 2005).

${ }^{39}$ Email correspondence with the author on March $13^{\text {th }}, 2006$.
} 
attests to his vision that geography is the ultimate sign (see Figure 1). ${ }^{40}$ He has, as Sacvan Bercovitch notes, transformed 'geography into eschatology'. 41

\section{Figure 1}

FOUR BEST-SELLING HITCHCOCK BOOKS (1993-2004)

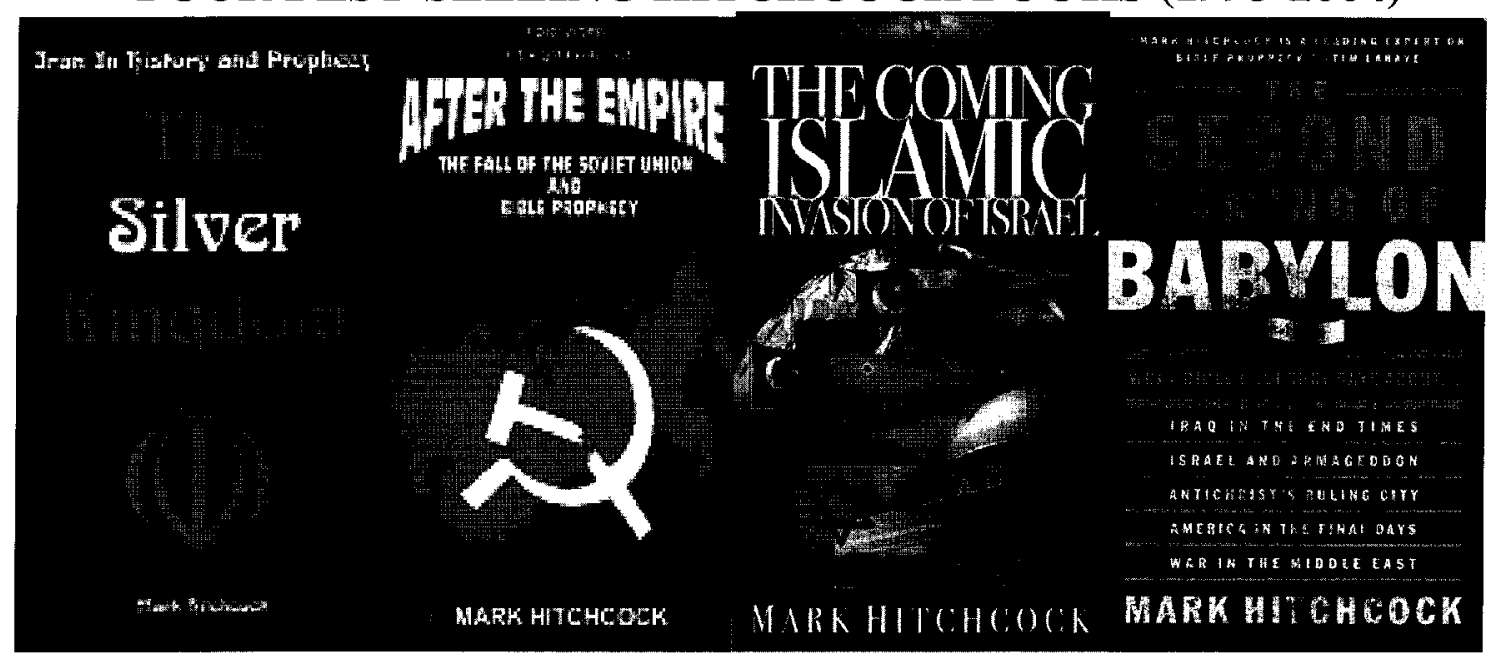

Sources: Mark Hitchcock (1993), (1994), (2002), (2003), respectively.

Hitchcock grew up in Oklahoma and has lived there his whole life with the exception of the three years he spent at the Dallas Theological seminary. Hitchcock comes from a long line of prophecy expounders and has studied prophecy for over 35 years. In his words:

I became a believer in June 1965 when I was watching a Billy Graham Crusade on TV. I grew up in Christian family and attended a strong Bible believing, Bible teaching church. My father worked at the FAA [Federal Aviation Administration]

\footnotetext{
${ }^{40}$ M. Hitchcock, The Silver Kingdom: Iran is History and Prophecy (Oklahoma City: Hearthstone Publishing, 1993); M. Hitchcock, After the Empire: Bible Prophecy in Light of the Fall of the Soviet Union (Wheaton, Ill: Tyndale House, 1994); M. Hitchcock, What on Earth is Going On? (Sisters, OR: Multnomah 2002); Hitchcock, Is America in Bible Prophecy? (Sisters, OR: Multnomah, 2003); Hitchcock, The Coming Islamic Invasion of Israel (Sisters, OR: Multnomah, 2002); M. Hitchcock, 'Alignment of the Nations: The Nations of Prophecy Are In the News, But How Do They Align With Scripture?', Interpreting the Signs (Jan. 2003); M. Hitchcock, 'President of Europe: An Update on the Movement Toward Political and Economic Union in Europe', Interpreting the Signs (Jan. 2003); M. Hitchcock, The Second Coming of Babylon; M. Hitchcock, What Jesus Says About the Earth's Final Days (Sisters, Ore.: Multnomah Publishers, 2003); M. Hitchcock, 'EU Signing Ceremony The Latest Event in the Reconstitution of the Roman Empire', Interpreting the Signs (Nov. 2004).

${ }^{41}$ This passage from S. Bercovitch, The American Jeremiad (Madison: University of Wisconsin Press, 1978) pp.41-42 is quoted in Campbell, Writing Security, p. 107.
} 
center in Oklahoma City for over 40 years. He taught a $7^{\text {th }}$ grade boys Sunday School class for 27 years. My grandfather was a missionary to Japan from 19231930. When he returned to Springfield, Missouri in 1930 he founded a couple of nondenominational churches in Springfield, Missouri. However, his main ministry was teaching the Bible on a local radio station in Springfield and teaching at various churches throughout the Ozarks in southern Missouri. He was a dispensational, premillennialist. I still have his 1917 Scofield Bible. He was very interested in End Time prophecy. He authored two books-one on Daniel and one on Revelation. ${ }^{42}$

Hitchcock attributes his interest in prophecy not to his lineage, however, but rather to Hal Lindsey's book Late Great Planet Earth (1970), which was the best selling non-fiction book of the 1970 s. $^{43}$ It is for this reason that Hitchcock's work will be juxtaposed to the work of Lindsey and John Walvoord, both of whom Hitchcock reveres as having a 'major impact on' his prophetic signs. ${ }^{44}$

Hitchcock's so called 'supersigns' are geographic constructs. What he calls the 'number one sign' is the modern state of Israel, which 'began in 1948 and continues to be fulfilled today as the Jews are being brought back to their land'. ${ }^{45}$ It is prophesised by all premillennial interpreters that Israel will make substantial territorial gains in the Middle East based on God's promise to Abraham for all the land West of the Euphrates to the 'river of Egypt' (Genesis 15:18), which will incite enmity among Muslim nations (see Figure 2). For security reasons, the Antichrist will make a seven-year peace pact with Israel only to later invade taking advantage of its weakened borders (Daniel 9:27, 11:4041; Ezekiel 38-39; Matthew 24:15-20). The late John Walvoord, a popular End Times writer and former president of the Dallas Theological Seminary, wrote in regard to the significance of Israel:

\footnotetext{
42 This information was gathered through email correspondence between Hitchcock and myself on April, $13^{\text {th }}, 2006$.

${ }^{43}$ Ibid.

44 Ibid.

${ }^{45}$ M. Hitchcock, 101 Answers To the Most Asked Questions About the End Times (Sisters, OR: Multnomah, 2001) p.36. Hitchcock told me that he has visited Israel twice and plans to return in June, 2006 (email Conversation March $13^{\text {th }}, 2006$ ).
} 
Of the many peculiar phenomena which characterize the present generation, few events can claim equal significance as far as Bible prophecy is concerned with that of the return of Israel to their land. It constitutes a preparation for the end of the age, the setting of the coming of the Lord for His church, and the fulfillment of Israel's prophetic destiny. ${ }^{46}$

In Hitchcock's theatrical and troubling words, 'now that the Jews are back in their land, the hammer of the end-times gun has been cocked. All that remains is for God to pull the trigger to set the end in motion'. ${ }^{47}$

Figure 2

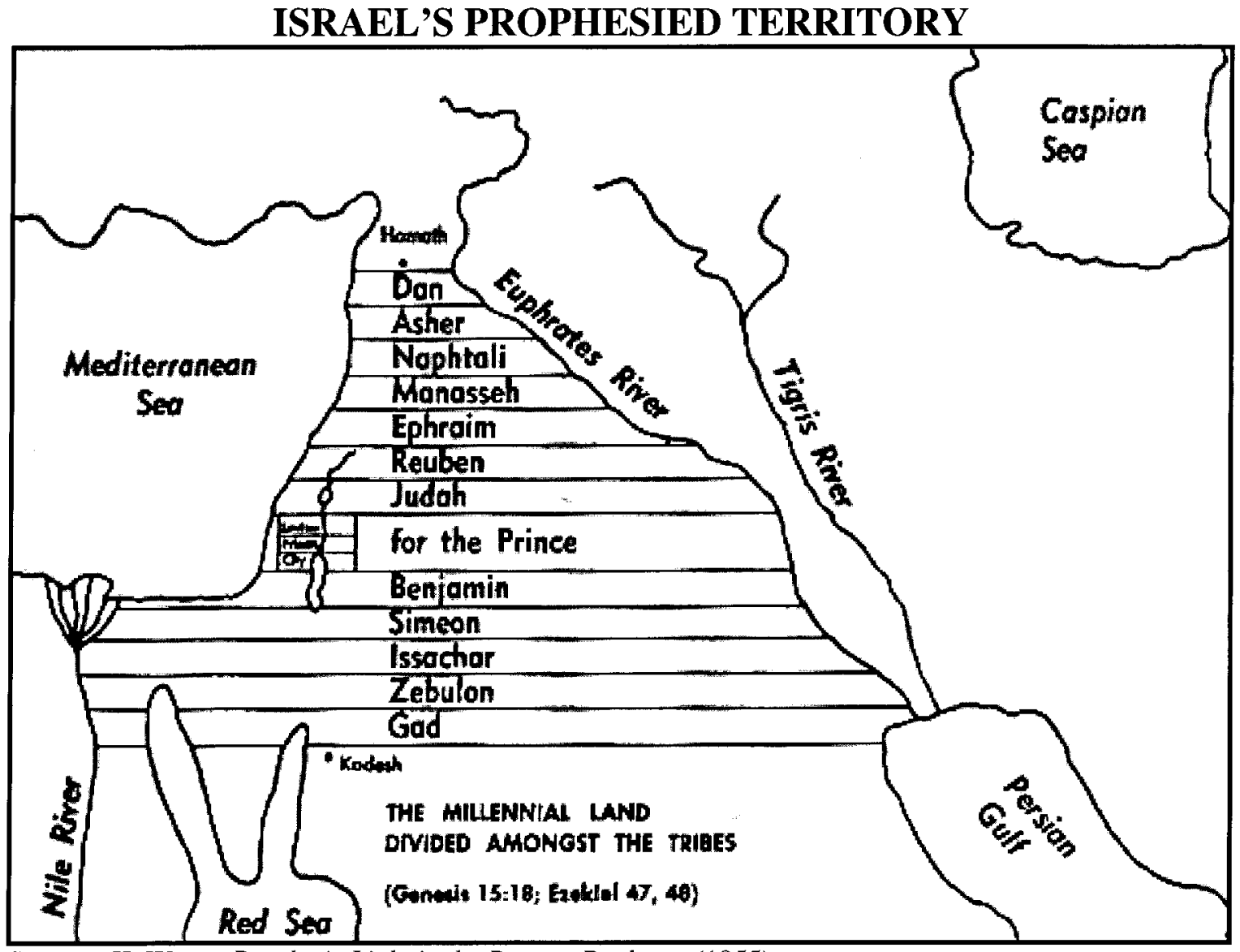

Sources: K. Wuest, Prophetic Light in the Present Darkness (1955).

Hitchcock's 'number two sign' is the 'reuniting of the Roman Empire' or 'Rome II'. Building from Daniel 2, Hitchcock often cites the work of his predecessors and peers

\footnotetext{
${ }^{46}$ J. Walvoord, Israel in Prophecy (Grand Rapids: Zondervan Pubishing House, 1967) p26.

${ }^{47}$ Hitchcock, 101 Answers, p37.
} 
like Lindsey and Walvoord, by interpreting Nebuchadnezzar's dreams of the Metallic Man to describe the rise and fall of what he calls the 'five world empires': the head of gold translating to Babylon, shoulders of silver as Medo-Persia, torso of Brass as Greece, legs of iron as Rome and the feet of iron and clay which is to represent the Antichrist's reunited Roman Empire. Hitchcock argues that these were the only true 'world empires' in history, but more than this and a symptom of it, 'the world' to Hitchcock is limited to North America, Europe, Northern Africa and those parts of Asia that make the evening news or fit well with his biblical schematic. In short, Britain was then not a world Empire because its colonial expanses were not part of Hitchcock's world.

Hitchcock's geopolitical exegesis revealed to him 'four main [geopolitical] power blocs led by four sovereigns'. ${ }^{48}$ The first is the King of the North (Daniel 11:40) which is Russia; the second is the King of the South (Daniel 11:40) or Egypt which will 'direct the Muslim league of nations'; the third is the Kings of the East (Revelation 16:12): 'Afghanistan, India, Pakistan, China, Japan, and/or Korea'; and the fourth is the King of the West (Daniel 2:40-43) or Confederation of Western nations-excluding all true believing Christians (see Figure 3). ${ }^{49}$ For Mark Hitchcock, the 'signs are everywhere',

\footnotetext{
${ }^{48}$ Hitchcock, Is America in Bible Prophecy? pp.77-78. For a map of his geopolitics, see Hitchcock, The Coming Islamic Invasion of Israel p.7.

${ }^{49}$ Daniel 11:40: 'And at the end time the king of the South will collide with him, and the king of the North will storm against him with chariots, with horseman, and with many ships; and he will enter countries, over them, and pass through'. Revelation 16:12: 'And the sixth angel poured out his bowl upon the great river, the Euphrates; and its water was dried up, that the way might be prepared for the kings from the east'. Daniel 2:40-43: 'Then there will be a forth kingdom as strong as iron; inasmuch as iron crushes and shatters all things, so, like iron that breaks in pieces, it will crush and break all these in pieces. 41: And in that you saw the feet and toes, partly of potter's clay and partly of iron, it will be a divided kingdom; but it will have in it the toughness of iron, inasmuch as you saw the iron mixed with common clay. 42: And as the toes of the feet were partly of iron and partly of pottery, so some of the kingdom will be strong and part of it will be brittle. 43: And in that you saw the iron mixed with common clay they will combine to one another, even as iron does not combine with pottery'. NAS.
} 
and interpreting them is 'like staring at a table covered with pieces of a jigsaw puzzle', where the Bible is the picture on the box and the pieces are planet Earth. ${ }^{50}$

\section{Figure 3}

\section{MARK HITCHCOCK'S PLACE TRANSLATIONS AND FOUR GEOPOLITICAL BLOCS}

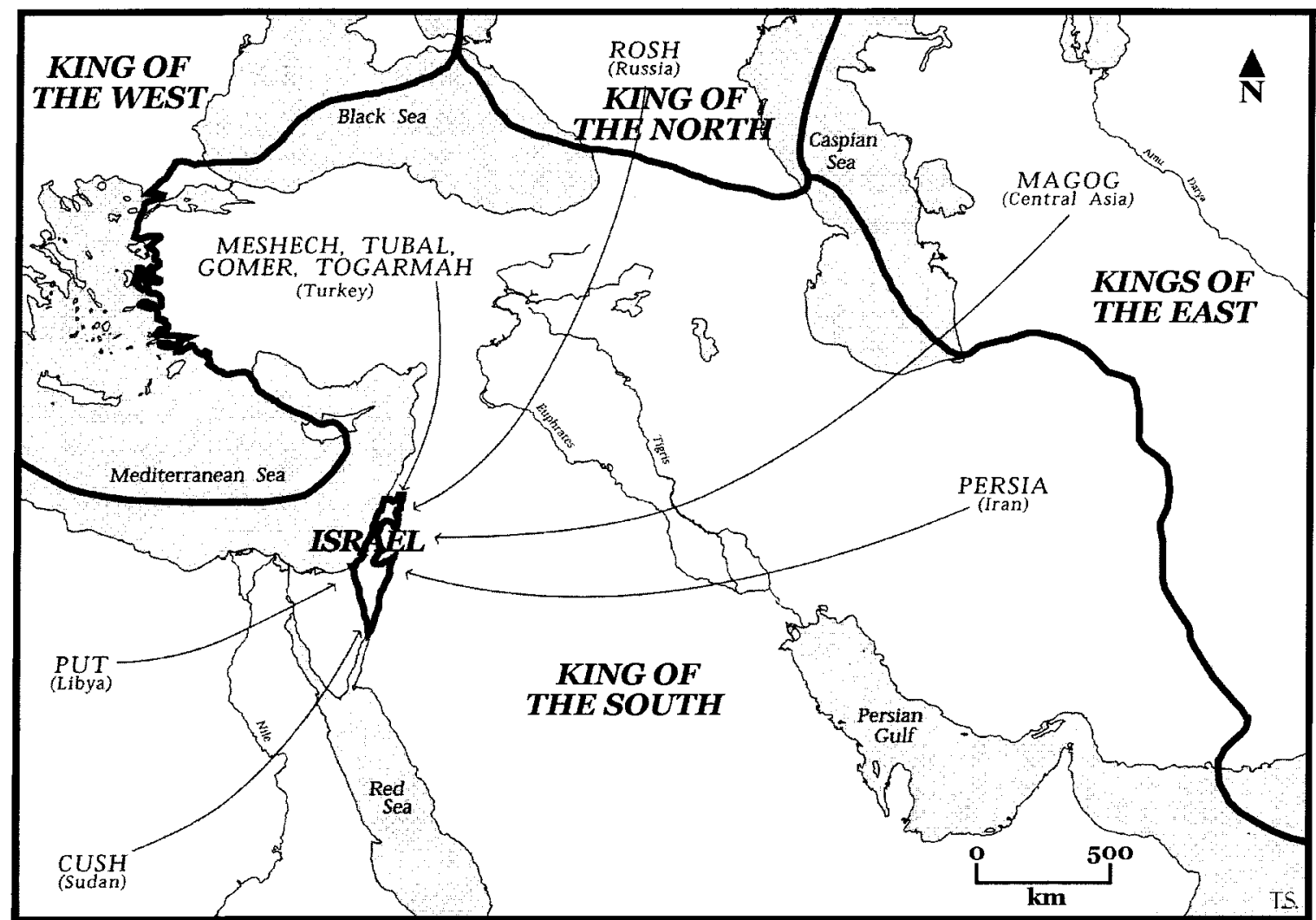

Sources: Tristan Sturm, Prophetic Eyes (2006).

Despite Hitchcock's formal theological training, he does not write 'formal geopolitics'. The excursive tabloid-like proliferation of his writing and his effusive rhetoric of moral certainties and us/them, Christian/Muslim dualisms would best be described as 'tabloid geopolitics'. ${ }^{51}$ Hitchcock seeks a 'shock and awe' reaction from his readers to help them make sense of a confusing world by constructing new enemies and

\footnotetext{
${ }^{50}$ Hitchcock, The Coming Islamic Invasion of Israel, pp.23-4.

${ }^{51}$ F. Debrix, 'Tabloid Realism and the Revival of American Security Culture', Geopolitics 8/3 (2003) pp.151-190; For 'popular geopolitics', see J. Sharp, Condensing the Cold War: Reader's Digest and American Identity (Minneapolis: University of Minnesota Press, 2000).
} 
villains conflated with the enemies of the United States through a collocation of biblical toponyms with the modern state system. He provides hard, fast, and easy answers in a 'tabloid medium [that] allows...[him] to deploy relatively ahistorical discourses in "contexts" that do not have to abide by rules of temporal and spatial contingency". ${ }^{52} \mathrm{He}$ reduces his arguments to grand theatrical metaphors with the intent to associate ideas with a visual model/illustration/instance, making them seem more 'real' or tangible. He writes, 'The house lights appear to be dimming. The curtain could go up at any moment. The Rapture could occur today, before you finish reading this page! ${ }^{53}$ The stage is his biblical geopolitics, the actors are the Other directed by God, and his text is a simple mental map of the world.

\section{Premillennial Dispensationalism and America}

Premillennialism exists predominantly in the United States. While prophecy is most pervasive in the American south (specifically Southern California, Texas and Oklahoma), it has diffused throughout the United States and has penetrated Mexico and Canada. ${ }^{54}$ Moreover, millions of Africans and also many Latin American evangelicals believe in

\footnotetext{
${ }^{52}$ Debrix, 'Tabloid Realism and the Revival of American Security Culture', p.158.

${ }^{53}$ Start Praying! Hitchcock, The Coming Islamic Invasion of Israel, p.74.

${ }^{54}$ The It Is Written television network rented out the conference room of Landsdown park, in Ottawa, every night from May $6^{\text {th }}$ to May $21^{\text {st }}, 2005$, to present their 'Multimedia presentation': Amazing Discoveries in Bible Prophecy. Prophecy expounder and interpreter, Dan Bentzinger presented on issues of war, peace and security. In his May 7th lecture, 'Beyond Iraq-Countdown to Eternity', Bentzinger preached for over an hour about the rise of Babylon in Iraq and its relation to prophecy as the new world capital where the Antichrist would locate his headquarters. In reference to Babylon rising, he said 'it is absolutely certain and the interpretation thereof...this is God's foresight, He's seeing this take place. He's telling you this is going to happen... we are living, according to Daniel 2 , in the very last part of this image' the image of the Apocalypse. On either side of him while he spoke, two $6 \times 6$ screens displayed a hypothetical theatre of world annihilation by Apache helicopters shooting buildings and atomic missiles being launched from bodies of water. Every evening hundreds of people were in attendance. Bentzinger mentioned there were over 500 people in attendance that night (May $7^{\text {th, }}, 2005$ ).
} 
prophecy, in part due to the influence of Pentecostal missionaries in the last forty years. ${ }^{55}$ An American Pew poll (2004) reported that 36 percent of respondents believed that the Book of Revelation was not a metaphor but rather 'true prophecy', ${ }^{56}$ while a recent Time/CNN poll found 59 percent of Americans believe prophecies in the Book of Revelation are going to come true. ${ }^{57}$ A 2004 Gallup poll reported 32 percent of Americans believed 'the Bible is the actual word of God and is to be taken literally, word for word' ${ }^{58}$ In 1987, 63 percent of Southern Baptist pastors declared themselves premillennial. ${ }^{59}$ Timothy Weber, president of Memphis Theological Seminary and apocalyptic historian, claims that premillennialists 'make up about one-third of America's forty million Evangelical Christians'. ${ }^{60}$ Premillennialism is preached by some $7^{\text {th }}$ Day Adventists, Mormons, Jehovah's Witnesses, Methodists, Presbyterians, Pentecostals, Methodists, Anglican protestants, and Branch Davidians, and is a relatively powerful force among, Southern Baptists and many independent Protestant churches such as Hitchcock's Faith Bible Church in Edmond, Oklahoma. ${ }^{61}$

\footnotetext{
${ }^{55}$ See Boyer, When Time Shall Be No More, p.4.

${ }^{56}$ A. Lieven, American Right or Wrong: An Anatomy of American Nationalism (New York: Oxford University Press 2004) p.144.

${ }^{57}$ G. Scherer, 'The Godly Must be Crazy: Christian-Right Views Are Swaying Politicians and Threatening the Environment', Grist Magazine (Oct. 2004) [http://www.grist.org/news/maindish/2004/10/27/schererchristian/].

${ }^{58}$ F. Newport, 'Who Are the Evangelicals?', Gallup News Service (June 24, 2005) [http://www.gallup.com/poll/content/default.aspx?ci=1690\&pg=1].

${ }_{59}$ Do remember, however, that both Jimmy Carter and Bill Clinton were Southern Baptists, and premillennialist or not, they were quite progressive in terms of social issues. See, Lieven, America Right or Wrong, p. 144.

${ }^{60}$ T. P. Weber, On the Road to Armageddon: How Evangelicals Became Israel's Best Friend (Grand Rapids, MI: Baker Academic, 2004) p.9.

${ }^{61}$ P. Boyer, When Time Shall Be No More, p.2. This does not mean that all 'born-again' or evangelical Christians are premillennial or even Right-wing. Although many premillennial prophecy writers conflate all Evangelical Christians in the United States-23 percent-to premillennial thought. I am cautious here to cite statistics about how many premillennialists live in America, some, like Hitchcock, have said that as many as 23 percent of Americans are premillennialists. See Hitchcock, Is America in Bible Prophecy? p.69. An example of my concern is when Gerald Ford felt compelled to declare himself 'born again' in 1976 even though he was an Episcopalian because Jimmy Carter was appealing to the electorate with his 'bornagain' persuasion. See Lieven, America Right or Wrong p. 141. Weber, On the Road to Armageddon, p.9.
} 
Of course, simply because people take purchase in such belief does not mean that they allow it to influence their everyday lives, and nor simply because one makes the claim to such beliefs does it mean that they read prophetic interpreters' texts or even the Bible. As George Gallup, Jr. and Jim Castelli report in one of their many polls of the religious leanings of the United States, 'Americans revere the Bible but by and large they don't read it'. ${ }^{62}$ However, as is argued in this thesis, even if such believers did read the Bible it may make little difference. Presuppositions are all too often the interpreting structure from which biblical text is read. We must bear in mind that humans are complex beings who act from myriad of discursive and non-discursive practices, presuppositions, values, morals and impulses.

Premillennialism-defining the deteriorating conditions on Earth believed by some Christians to precede Christ's return to Earth (hence 'pre-') and His millennium reign-represents a theological structure of thought that has existed in Christianity since the first century of the Common Era (CE). However, premillennial dispensationalism was developed most thoroughly and convincingly in the mid $19^{\text {th }}$ century by British writer John Nelson Darby (1800-1882) who, from 1859 to his death in 1882, toured the United States six times preaching dispensationalism as the true intention of God's word. ${ }^{63}$ Darby's influence in America spurred many followers including Cyrus Scofield who included in his Study Bible notes (1901) the exegesis of Darby and his Plymouth Brethren followers. The Darbyites were also called Dispensationalists because they broke history into periods or 'dispensations' that culminate in Christ's return and thousand year

\footnotetext{
${ }^{62}$ G. Gallup, Jr. and J. Castelli, The People's Religion: American Faith in the Nineties (New York: Macmillian Publishing, 1989) p. 60.

${ }^{63}$ Boyer, When Time Shall Be No More, p.90.
} 
rule of Earth. ${ }^{64}$ While the last dispensation ended with the crucifixion of Christ, the Bible is silent on the current dispensation, or 'Church age'. Acting as a vessel to evangelise dispensational thought, Scofield's Study Bible solidified the movement in the United States. Scofield predicted that the Jews would return to Israel and the evil 'Gog' of Ezekiel 38 was Russia. ${ }^{65}$ These two interpretations would win Scofield's thoughts and premillennialism in general scores of followers after the establishment of modern Israel and the onset of the Cold War. Further, several events preceding this in the United States-the American Civil War, both World Wars and the Great Depressionconsolidated the idea that society was in a declining state, this despite apparent efforts to quell violence and suffering. By having knowledge of God's 'great plan', premillennial beliefs became a way of dealing with these unfortunate events, a reversal of that which once seemed so pernicious in the hands of the 'enemy'. ${ }^{66}$

Premillennialists believe that the next dispensation is one ever-nearing theatrical moment when all of those true believers who have placed their faith in Jesus Christ will be Raptured into the sky with Christ to witness the drama on stage-earth from their seats in Heaven (John 14:1-3; 1 Corinthians 15:50-58; 1 Thessalonians 4:13-18; see Figure 4). ${ }^{67}$ Those 'left behind' ${ }^{68}$ will be embroiled in famine, plagues, natural disasters and

\footnotetext{
${ }^{64}$ C. Koester, Revelation and the End of All Things (Grand Rapids, Mich.: William B. Eerdmans Publishing, 2001) p.19.

${ }^{65}$ Boyer, When Time Shall Be No More, p.98. Ezekiel 38 is too lengthy to annotate here. See C. I. Scofield (eds.) The Holy Bible, King James Version (KJV) (Korea: Oxford University Press, 1996 [originally published in 1901]) pp.883-884.

${ }^{66}$ For a more in-depth look at the history of premillennialism, see Boyer, When Time Shall Be No More and C. Koester, Revelation and the End of All Things. For studies on the rhetorical qualities of premillennial thought, see F. L. Borchardt, Doomsday Speculation as a Strategy of Persuasion: A Study of Apocalypticism as Rhetoric (Lewiston: The Edwin Mellon Press, 1990) and B. Brummett, Contemporary Apocalyptic Rhetoric (New York: Praeger, 1991). For a political and theological critique, see Northcott, An Angel Directs the Storm.

${ }^{67}$ C. H. Dyer, The Rise of Babylon: Is Iraq at the Center of the Final Drama? (Chicago: Moody Publishers, 2003 [Originally published in 1991]) p.140. The idea of the Rapture is predominantly derived from 1

Thessalonians 4: 16-17, in which St. Paul says: 16: 'For the Lord himself shall descend form heaven with a
} 
environmental degradation. These catastrophes will kill three in four people in the seven year Tribulation period (Revelation 6-19; Matthew 24:21) that follows the Rapture. And those armies of Satan first led by the 'Muslim alliance' and then by the Antichrist's 'Roman Empire' (or European Union) whose 'evil' eyes are set on the destruction of Israel will be completely wiped out by the hand of Christ in the worst battle the globe has ever seen. Even taking action to reverse this apocalyptic violence is seen as a challenge to Christ's sovereignty because crisis is part of the divine End Time plan. The premillennialist 'scorns all efforts made in the name of religion to correct the ills of society' for 'to inaugurate any programme of social betterment or to set the church as a whole upon an upward course would be to thwart the divine purpose and to delay the advent of Christ' ${ }^{69}$ This is a political act and convenient limitation to responsibility for social betterment because the improvement of the present would degrade the quality of the 'sign', thereby artificially postponing the End Time. ${ }^{70}$ This forces premillennialists to capitulate to history because it is guided by God. Premillennial fin de millennium prophecy remains then an impassable boundary between the work of humans and that of God. Consequently, only God can renew the Earth to its state before the 'fall from grace'. Premillennialists are then devoted to a divine omnipotence and a feeling of human powerlessness.

\footnotetext{
shout, with the voice of the archangel, and with the trumpet of God; and the dead in Christ shall rise first. 17: Then we who are alive and remain shall be caught up together with them in the clouds to meet the Lord in the air, and thus we shall always be with the Lord'. New American Standard Bible (NAS) (Anaheim, California: Foundation Publications, 1995).

${ }^{68}$ 'Left Behind' - a series of premillennial novels started by Tim LaHaye and Jerry Jenkins and published by Tyndale - is the best selling fiction series in American history with over 60 million copies sold in just over ten-years.

${ }^{69}$ Shirley Jackson Case summed premillennialism this way in his book The Millennial Hope: A Phase of War-Time Thinking (Chicago: University of Chicago Press, 1918) pp.235-37.

${ }^{70}$ Borchardt, Doomsday Speculation as a Strategy of Persuasion, p.139.
} 
In Hitchcock's words, 'during the last half of the Tribulation, the Antichrist will rule the world politically, economically, and religiously. The entire world will give allegiance to him or suffer persecution and death (Revelation 13:1-18)... [during] the Campaign or War of Armageddon... when all the armies of the earth gather together to come against Israel and attempt once and for all to eradicate the Jewish people (Revelation $14: 19-20 ; 16: 12-16 ; 19: 19-21)$ '. This mayhem will be brought to a close with 'The climactic event of human history...[with] the literal, physical, visible, glorious return of Jesus Christ to planet earth. He will destroy the armies of the world gathered in Israel and set up his kingdom on earth, which will last for one thousand years (Revelation $19: 11-21)^{, 71}$

\section{Figure 4}

'GOD'S BLUEPRINT FOR THE END TIMES'

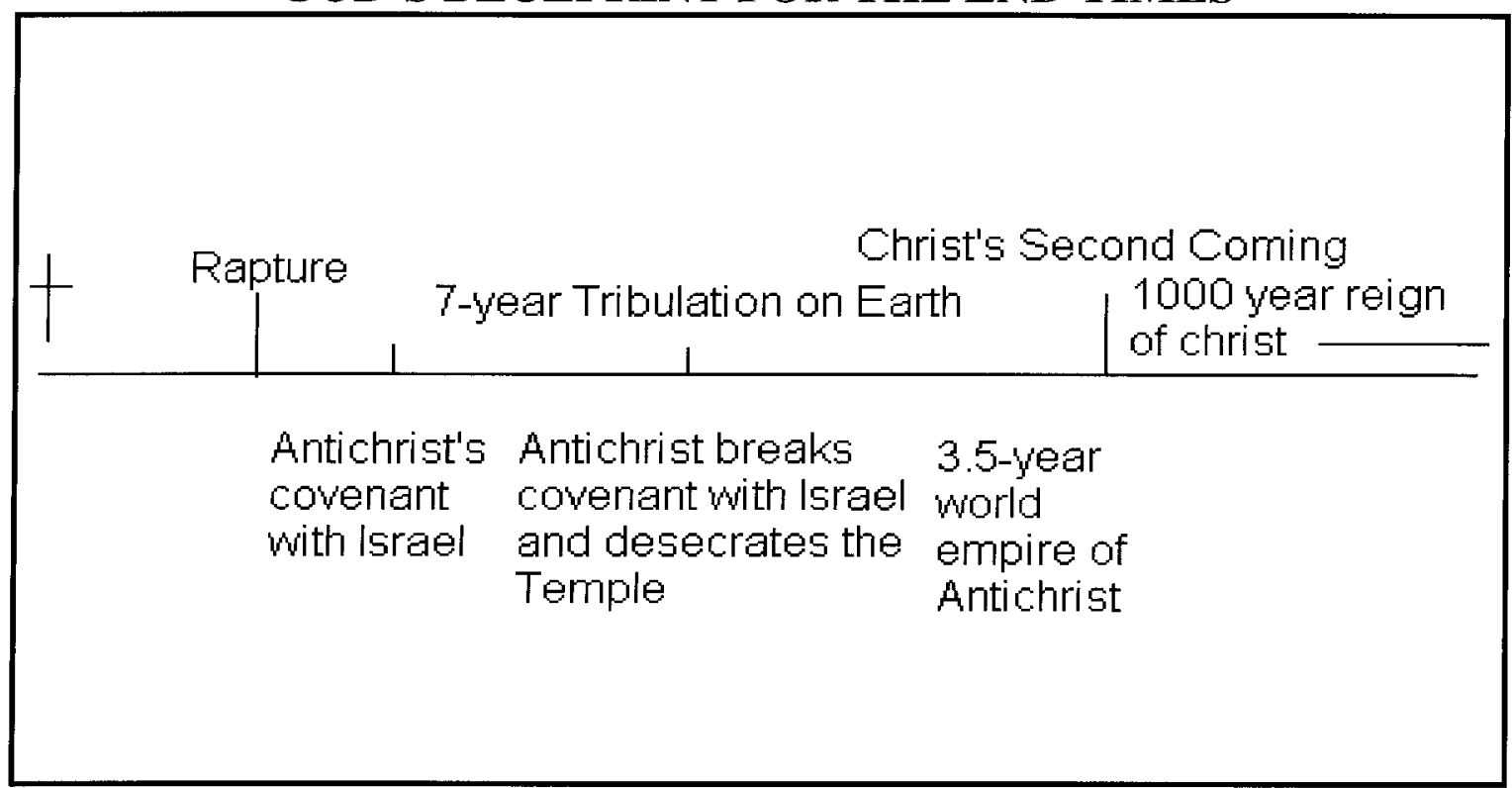

Sources: Hitchcock, Seven Signs of the End Times (2002).

\footnotetext{
${ }^{71}$ Hitchcock, 101 Answers, pp.10-11.
} 
Beside premillennialism, there are two other Christian interpretations of history: Amillennialism and Postmillennialism. With respect to the former, the prefix $a$ denotes a negation of the word millennium literally meaning, then, 'no millennium'. It is the dominant Christian position and is held by the Roman Catholic Church, the Greek Orthodox Church as well as a large percentage of Protestant churches. Amillennialists believe that the millennium is happening now between Christ's first and second coming; it is an allegorical or historicist reading of biblical apocalyptic. The genealogy of this view is usually traced to St. Augustine (354-430 CE). Augustine's masterpiece, the City of God, (413-426), though of the impression that history was shaped by eschatology, denied the immanence of a millennium or earthy Kingdom of God, relegating apocalyptic passages to metaphor. Shirley Jackson Case, premillennialism's first scholarly and modern critic of the early $20^{\text {th }}$ century, writes that to Augustine the Babylon of Revelation was not a specific nation or city, but rather a representation of the "community of unbelievers set in opposition to the faithful people of the city of God [which is Jerusalem]' ${ }^{72}$ To Augustine, the Last Judgement was the final separation of Babylon and Jerusalem. ${ }^{73}$ However, it was not simply Case who took on this interpretation; Babylon usually represented everything the Christian was to stand in opposition to. This view was also held by John Calvin and Martin Luther. With regard to Lutheran theology, Luther's 'repudiation of all who sought in [Revelation] a clear key to current and future events' had much influence on Protestantism and millenarianism. However, this did not stop both

\footnotetext{
${ }^{72}$ S. J. Case, The Millennial Hope: A Phase of War-Time Thinking (Chicago: University of Chicago Press, 1918) p. 182.

${ }^{73}$ Boyer, When Tomorrow Shall Be No More, p.49.
} 
Luther and Calvin from naming the Pope as the Antichrist, a move that had the clear underpinnings of being political rather than eschatological. ${ }^{74}$

Postmillennialism, like amillennialism, articulates that the millennium is a period between Christ's first and second coming and is not a literal thousand-years. The difference lies in evangelism. That is, postmillennialists believe that all people of the world will find Christ, become Christian and therefore create a perfect earthly Christian utopia. In short, postmillennialists believe the world will become better and better as the gospel is spread throughout the world. Only when this 'purification' is achieved will Christ return to earth to rule for eternity. This view was popularized by Daniel Whitby (1638-1726), an Arminian minister of the Church of England and came to fruition in the mid- $18^{\text {th }}$ Century as an idea of novelty rather than return as is seen in the excited references to all the new manifestations of the age - the new lands, the new learning, the new books, the new missionaries'. ${ }^{75}$ However, Augustine's figurative interpretation began a foundation for the later development of postmillennialism. As Walvoord saw it, Augustine 'held that the age between the first and second advents is the millennium of which the Scriptures speak and that the second advent would occur at the end of the millennium. This is definitely a postmillennial viewpoint as it places the second advent after the millennium'. ${ }^{76}$ This interpretation is also an amillennial position, which is most associated to Augustine's eschatology because of his pessimism toward world history and humanity. Despite Calvin's well known optimism for the world (over Luther and Augustine's pessimism) he also made fatalistic statements: 'There is no reason, therefore,

\footnotetext{
${ }^{74}$ Ibid, p.61.

${ }^{75}$ M. Reeves, The Influence of Prophecy in the Later Middle Ages: A Study of Joachimism (London: Oxford University Press, 1969), p. 502-3.

${ }^{76}$ J. F. Walvoord, The Millennial Kingdom (Grand Rapids: Zondervan, 1959) p.19.
} 
why any person should expect the conversion of the world, for at length-when it will be too late, and will yield them no advantage'; Augustine, Luther, and Calvin, then, are most noted for amillennialism. ${ }^{77}$

Both amillennialists and postmillennialists agree that the covenant of David is to be understood figuratively, which explains that the descendants of David, applied directly to Jesus (Luke 1:32-33) would rule over kingdom Earth. Premillennialists believe that Christ will sit on David's throne in Israel during His thousand year reign over Earth (See Acts 1:6-7). There is no doubt that 'dispensationalism' fits into Hitchcock's premillennialist structure; however, throughout this thesis, this teleology will be referred to as 'premillennialism' and not 'premillennial dispensationalism' for simplicity. ${ }^{78}$ Hitchcock does define premillennialism, postmillennialism and amillennialism in the introductory section of his book 101 Answers to the End Tmes, but the section that follows explains why he has chosen premillennialism as his guiding light to history and prophecy fulfillment. In his words, it is the:

1. Earliest View;

2. Most Natural Reading of Revelation 20:1-6;

3. Literal One Thousand Years in Revelation 20:1-6. ${ }^{79}$

Suggesting it is the earliest view, though in part correct in that early Christians anticipated the immanence of Christ's return, he is suggesting that premillennialism is a

\footnotetext{
${ }^{77}$ J. Calvin, Commentary on a Harmony of the Evangelists, Matthew, Mark, and Luke (Grand Rapids: Baker Book House, n.d.), p. 147 quoted in M. Reeves, The Influence of Prophecy in the Later middle Ages: A Study in Joachimism (Oxford: Clarendon Press, 1969) p.501.

${ }^{78}$ Hitchcock does not mention 'dispensationalism' as a defining term for his historical structure and nor does he refer to it when defining other historical structures of Christianity. When asked about this absence of reference in his material he side-stepped the question by stating that 'all dispensationalists are premillennialists but not all premillennialists are dispensationalists' (email correspondence with Hitchcock on April 13 $3^{\text {th }}, 2006$ ). This could be considered an attempt to 'mainstream' dispensationalist eschatology in American Protestantism. However, one could argue this, though not within the bounds of this thesis, but one could also argue that premillennial dispensationalists are very incredulous of ecumenical associations.

${ }^{79}$ Hitchcock, 101 Answers, 25.
} 
timeless construction. With regard to the second 'natural' reason, he writes 'the premillennial position is the clearest, most natural reading of Revelation 20:1-6. This is the passage in the Bible that specifically mentions the thousand-year reign of Christ. It occurs in Revelation immediately after the second coming of Christ (Revelation 19:1121). In Revelation 19-20, Christ's coming is clearly before (pre) the Millennium or thousand-year reign'. ${ }^{80}$ In 'naturalizing' premillennialism he is simultaneously naturalizing his geopolitics through a performance of the world in the image of the Bible.

Premillennial theory as understood in this thesis, like any theory, is a modality of power that attempts to imagine how to reconstruct the world to be better understood. As Cox makes clear, 'theory is always for someone and for some purpose'. ${ }^{81}$ Theory as a technology of power, in Foucaudian terms, also has influence over the temporal and the spatial, the present and future, here and there. It is not within the bounds of this paper to map the direct effects of premillennial theory; concern lies in how it was made possible for Hitchcock to construct his geopolitics as 'natural' and 'ordained'.

\section{The Five Acts of the Play}

The first chapter of this thesis illuminates the geopolitics of premillennialism through a literature review of the project 'Critical Geopolitics'. This chapter weaves 16 years of research from Dalby and Ó Tuathail to Dodds and Campbell, in order to provide a short overview of the project and where this thesis fits within its taxonomy. There is no single text that dominates this work and it is for this reason that this text is not paradigmatic, but is rather a file or monograph in the diverse intersections of International Relations (IR),

\footnotetext{
${ }^{80}$ Ibid, p28.

${ }^{81}$ R. Cox, 'Social Forces, States and World Orders' in R. Keohane (ed.) Neorealism and Its Critics, (New York: Columbia University Press, 1986) p.207.
} 
Geography and Religious Studies. Because geopolitics as a term and a strategy really came into fruition as a security discourse circa World War II, it inevitably was studied by International Relations (IR). The 'critical' (or 'dissident' in IR) adjective was also very timely, coming at the end of the Cold War, where political geographers as well as those studying International Relations sought to address the connection between ideas and political practices associated with spatial expansion and domination. After the 1990s geopolitics was an interdisciplinary affair, making use of the Marxist world systems approach, quantitative thought in International Relations and work on gender and poststructuralist writing. ${ }^{82}$ The first chapter section asks how one could be critical of a belief system like premillennialism? It argues that premillennialism is an ideological construction and should not be privileged as religion. However, this thesis does not take part in Nietzschian nihilism or secularization theory from which to critique Christianity or God. ${ }^{83}$ Rather, it is written to lay bare the strategies Hitchcock uses toward a geopolitics of enmity. The second section defines what has been termed for this thesis 'Apocalyptic geopolitics'. This is done because this project did not fit neatly into the categories of Critical Geopolitics; that of Formal/Popular/Practical.

Chapter 2 formulates a methodological reading strategy. The first section defines 'perfomance', 'performitivity', and 'theatre' as used in this thesis. It argues that spaces

\footnotetext{
${ }^{82}$ K. Dodds, 'Political Geography III: critical geopolitics after ten years', Progress in Human Geography. 25/3 (2001) pp.470-71.

${ }^{83}$ See F. Nietzche Human, All Too Human. M. Faber (trans.) (Lincoln: University of Nebraska Press, 1996 [Originally published in 1878]). On 'Secularization Theory' see B. Wilson, Religion in Secular Society: A Sociological Comment (London: Watts, 1966). For a recent revival and debate on the idea that the world is progressively undergoing secularization, see P. L. Berger (ed), The Desecularization of the World; Resurgent Religion and World Politics (Washington: WB Eerdmans, 1999) as a critique of this notion, and see S. Bruce, God is Dead: Secularizaiton in the West (Oxford: Clarendon Press, 2002) as a work empirically supporting secularization theory. On challenging the idea that we live in a 'secular' world, see T. Asad, Formulations of the Secular: Christianity, Islam, Modernity (Stanford: Stanford University Press, 2003).
} 
and not simply gender or other social constructions are performed. The second section outlines the discourse analysis that takes up Foucault's later work on 'Genealogy'. It outlines how Hitchcock's works will be read in terms of power relations. The third section outlines Foucault's definitions of 'transcendence' and 'transgression' applied in the analysis chapters that follow. The grounding notions of transgression--engaging with the world-are applied to Hitchcock's transcendent-escape from the world: his view from Heaven in the Rapture and the Pulpit from his position as a pastor in society. Further, de Certeau's work on 'strategies' and 'tactics', albeit informed by Foucault's work, is used as a guide to outline the strategies Hitchcock uses to be able to write his Apocalyptic geopolitics. A 'strategy' to de Certeau, 'assumes a place that can be circumscribed as proper and thus serves as the basis for generating relations with an exterior distinct from it'. ${ }^{84}$ That is, a strategy is a place-making mode from which all others can be determined. This for Hitchcock is America before the Rapture and Heaven after it.

Chapter 3 or 'Act 1' applies the guiding principles outlined in chapter 2 . It problematizes Hitchcock's visual methods for the mise en scene or staging of religious 'truths' ${ }^{85}$ It argues that his theatrical metaphors of 'stage Earth' are made possible through the transcendent qualities of the Rapture that disembody and situate his reading of space in Heaven. Furthermore, his use of 'Author-ity', that is Authorship and Authority as a Pastor and Doctor, is used to suggest his interpretations are the writings of God. This strategy absolves his work from critique and also secures the theory of premillennial dispensationalism as the true form of history. Detaching Hitchcock from his

\footnotetext{
${ }^{84}$ M. de Certeau, The Practice of Everyday Life (Berkley: University of Califonia, 1984) p.XIX.

${ }^{85}$ Agnew, Geopolitics, pp.11-31.
} 
earthy life moves him to a transcendental position from which to observe and make 'sense' of the world.

Chapter 4 or 'Act 2' argues that Hitchcock's ability to 'see' the world as a tangible whole from the vantage point in Heaven, the Bible and the Pulpit, is a necessary condition of his geopolitics. Hitchcock's particular mise en forme of the world is outlined and compared to the geopolitics of Cold War prophecy writers like Lindsey, LaHaye and Walvoord. ${ }^{86}$ It is argued that premillennial geopolitics is always politically contingent from the territory of reference-in this case the United States where during the Cold War the 'evil' that would destroy Israel was Communist Russia, while Hitchcock's geopolitics have been recentred to the Muslim Middle East. In showing this biblical strategy toward a vision of the 'whole world' and re-script(ur)ing of premillennial geopolitics, Hitchcock's geopolitics are shown to be political constructions.

Chapter 5 or 'Act 3' argues that the transcendence afforded to Hitchcock by God through the Bible grant him a blessing of omniscience; one that tells him how the Other-defined by homogeneous units—will act during Armageddon. The Rapture on the other hand, provides a method of escape from Armageddon. Using the work of Edward Said, Simon Dalby and Derek Gregory, Hitchcock's texts are read as Othering strategies between the borders of Heaven and Earth, and America and the Middle East. ${ }^{87}$ It is argued that the production of the binary categorization of evil conceals the strategic aims of that very apparatus of production by postulating evil as the cause of Armageddon.

\footnotetext{
${ }^{86}$ H. Lindsey, The Late Great Planet Earth (Grand Rapids, MI: Zondervan Books, 1970); T. LaHaye, The Beginning of the End (Wheaton, IL: Tyndale, 1972); J. F. Walvoord, Armageddon: Oil and the Middle East Crisis (Grand Rapids, MI: Zondervan, 1974).

${ }^{87}$ E. Said, Orientalism (New York: Vintage, 1979); D. Gregory, The Colonial Present: Afghanistan, Palestine, Iraq (Malden, MA: Blackwell, 2004); S. Dalby, Creating the Second Cold War: The Discourse of Politics (New York: Guilford, 1990).
} 
Hitchcock's construction of 'evil' Others helps him justify his End Time violence beyond the American horizon to shore-up premillennialism as 'good' relative to Islam as 'evil'. The othering process is a mise en sens ${ }^{88}$ that gives premillennialism meaning by making the world intelligible through an articulation of alterity. Hitchcock's strategy toward this end is 'dis-orient-ed' from the Bible by writing Hitchcock's texts as a political move in tandem with American foreign policy.

The concluding chapter of this thesis offers other areas of scholarship on religion and geopolitics. It also takes up the us/them dualism at the root of the premillennial ontology and attempts to show how premillennialism has had material impacts on the world beyond influence on belief. It works through the religious performances and speech utterances of George W. Bush as Messianic and prophetic and also outlines premillennial attitudes and sentiments toward environmental degradation and Israel. The last section asks how premillennialism can break the chain of signifying geographies of evil by showing other possibilities foreclosed by Hitchcock's interpretations. It is the 'erasure of certainty $^{, 89}$ that razes the heads of the Beasts in the Book of Revelation; one that celebrates an 'eruption of contingency"90 and possibility rather than the dangerous assumption that the end of the word is nigh.

\footnotetext{
${ }^{88}$ On 'mise en scene', 'mise en forme, and 'mise en sens' see, M. de Larrinaga, Alterity, Social Order, and the Meaning(s) to Security (Unpublished PhD dissertation, University of Ottawa, 2002) p.124.

${ }^{89}$ Campbell, Writing Security, p. 18 .

${ }^{90}$ ibid.
} 


\section{Chapter 1:}

\section{Critical and Apocalyptic Geopolitics}

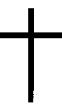

The purpose of this chapter is to define and situate this research in the subfield, Critical

Geopolitics. This chapter is split into two sections. The first is a short background to the literature called Critical Geopolitics and where this research fits into its taxonomy. This section is important in outlining where this research takes its cues and also how Critical Geopolitics has led up to this research. It also poses the question: how can one be 'critical' of religion as a belief system? The second section will define what is coined 'Apocalyptic geopolitics' within the taxonomy of Critical Geopolitics. This term is modest in its ability to encompass a body of literature and is careful not to blur important distinctions between theorists, contexts and modes of narration/representation. It is not, however, confined to Christian discourses on the Apocalypse. Rather, it can also encompass secular geopolitical designs of the end of the world.

\section{Critical Geopolitics}

The term geopolitics came to being in the late nineteenth century most often linked to Halford Mackinder who saw geography as seeing not writing. ${ }^{1}$ Here then lies his conception of $a$ geopolitics as a visually central act of imagining space. However, the term 'geopolitics' was first used by Rudolf Kjellen in 1899. The term became the 'strange

\footnotetext{
${ }^{1}$ G. Ó Tuathail, Critical Geopolitics: The Politics of Writing Global Space (Minneapolis: University of Minnesota Press, 1996) p.94.
} 
attractor' for many related fields of study at that time. ${ }^{2}$ But because of this attraction the definition became weighted with a barrage of meanings thus stringing the definition of geopolitics so thin that it became virtually meaningless. Michael Shapiro, in Ó Tuathail's terms, describes geopolitics as an institutionalization of 'state-centric discourse' that seeks to pacify and homogenize international space. Rob Walker, again in Ó Tuathail's terms, speaks of geopolitics as the ontological determination of International Relations (IR) that delineates the inside from the outside through a boundary making process. And to Henry Kissinger it came to mean the space of global politics. ${ }^{3}$ Ó Tuathail and Agnew in an earlier definition suggest, 'the study of geopolitics is the study of the spatialization of international politics by core powers and hegemonic ones'. ${ }^{4}$ There are evident and Eurocentric problems with this definition, of course. It is to suggest that non-'hegemonic' or 'core' states or even people or even religions do not 'geo-graph' with convincing results as though political elites were in some way separate from culture, or outside hegemony. ${ }^{5}$ Ó Tuathail would later correct himself in saying 'geographical knowledge is produced...from the classroom to the living-room, the newspaper office to the film studio, the pulpit to the presidential office' ${ }^{6}$ But Ó Tuathail would continue to stress the 'elite' geopolitics as 'the politics of writing global space', which is most useful for his scrutiny of its discursive practices. He continues that the act of geo-politicking is done by those 'who wish to make the world in the image of their maps' ${ }^{7}$ Hence, in geopolitics,

\footnotetext{
${ }^{2}$ S. Dalby and G. Ó Tuathail, 'The Critical Geopolitics Constellation: Problematzing Fusions of Geographical Knowledge and Power', Political Geography. 15/6-7 (1996) p.451.

3 These three definitions are found in, Ó Tuathail, Critical Geopolitics, p. 16-17.

${ }^{4}$ G. Ó Tuathail and J. Agnew, 'Geopolitics and Discourse: Practical Geopolitical Reasoning in American Foreign Policy', Political Geography. 11/2 (1992) p.192.

${ }^{5}$ J. Sharp, 'Re-maculinizing Geopolitics? Comments on Gearoid Ó Tuathail's Critical Geopolitics'. Political Geography. 19/3 (2000) pp.362.

${ }^{6}$ Ó Tuathail, Critical Geopolitics, p. 195.

${ }^{7}$ ibid, p. 20 .
} 
maps are drawn and the theory is made to fit in a deductive fashion. Ó Tuathail later defines geopolitics as the production of 'international politics as theater' whereby 'production' means making visible what was formerly not. ${ }^{8}$ It is this 'theater making' definition of geopolitics that is used in this thesis. Politics in this thesis, is understood, following Richard Beardsworth's definition 'as designating the domain or practice of human behaviour which normalizes the relations between a subject and its others (other human subjects, nature, technics, or the divine). I understand the term the 'political' as the instance that gathers or founds such a practice as a practice ${ }^{, 9}$ The political, as the theatrical, pre-determines the textual and physical terrain upon which the operation of politics conducts itself.

Dalby redefines geopolitics as a boundary producing performance of excluding and internalizing. Dalby writes that an important 'moment of geopolitical discourse is the division of space into "our" place and "their" place; its political function being to incorporate and regulate "us" from "them", the same from "the other". ${ }^{10}$ Otherness involves exclusion and, for Dalby, exclusion is inherently spatial. For Dalby, the practice of critical geopolitics is understood as an investigation of the origin and effects of discursive structures. In other words, how discourses are constructed through discursive practices that are often founded on commonsensical assumptions. It is here that Dalby devotes most of his theoretical introspection by challenging naturalized spaces and states that were built politically and culturally without reflection. ${ }^{11}$

\footnotetext{
${ }^{8}$ Ibid, p. 29.

${ }^{9}$ R. Beardsworth, Derrida and the Political (London: Routledge, 1996) p.158.

${ }^{10}$ S. Dalby, 'Critical Geopolitics: Discourse, Difference, and Dissent', Environment and Planning D: Society and Space 9 (1991) pp.261-283.

${ }^{11}$ See, for example, S. Dalby, 'Geopolitical Discourse: The Soviet Union as Other', Alternatives: Social Transformation and Humane Governance 13/4 (1988) pp.415-42.
} 
How then can one be critical of something that is ephemeral and at best individualistic? First, there cannot be a consensus as to what defines geopolitics, particularly when one understands that all definitions are inherent generalizations and constructed with brevity. Thus a 'definition', by definition, must leave out information. Second, this provides for Critical Geopolitics the ability to explore both context and text more freely, and across academic spaces that might otherwise limit what one can say or do. Each analysis then is also context specific. Third, the question is not "what is geopolitics?' but 'how geopolitics' and the 'geopolitical tradition' have been 'textualized with certain meanings at various times and in various contexts'. ${ }^{12}$

This melange of meanings can be useful as well, particularly for strategic studies, in that it can be recycled and repeated to take on historical meanings or can be used to invoke in the reader or listener a 'new' sense of meaning. Dalby and Ó Tuathail, however, see the melange of meaning to be useful in a critical geopolitics thus not being centered on one 'single principal or final reconciliation around a revealed one'. ${ }^{13}$ In other words, structuralist under-griding is not to be found in a single definition of geopolitics, however, this is precisely what 'elites' and prophecy expounders do: they attach past and underlying meanings to a word like 'geopolitics', or in a more pragmatic case, like 'Islam', and center it on a region of the world like the Middle East without regard for variations of meaning or locations of Muslims around the world. The point of this fleshing out of definitions is important to this thesis because it shows the breadth and complexity of its history. In short, there is no 'it' as a stable or singular thing called

\footnotetext{
${ }^{12}$ Ó Tuathail, Critical Geopolitics, p.66.

${ }^{13}$ Dalby and Ó Tuathail, 'The Critical Geopolitics Constellation', p.452.
} 
geopolitics. It is in part for this reason that Hitchcock's maps can be defined as geopolitics.

Ó Tuathail makes the distinction between three categories of geopolitics, arguing that geopolitics does not always stem from governments or other 'elite' networks (See Figure 5). ${ }^{14}$ The first is 'Practical geopolitics' which can be summarized as the everyday governmental politicking and making-of-place by statespersons and military commanders. The next is 'Formal geopolitics', which is the spatializing practices of strategic thinkers and public intellectuals. The third geopolitics is 'Popular geopolitics'. Again, this is a space-making practice, but this time it is done through the media, popular culture and other forms of public knowledge. These geopolitical themes will help categorize this thesis and suggest future paths and neglected aspects of what a Critical Geopolitics is, or could be.

Critical Geopolitics complemented work in political geography where geography itself during the 1980s was put into question for its traditional practice of bounding space and thus generalizing what those boundaries internalized. By 'traditional' is meant those research agendas that focused on macro-level or meta-geographies like state borders. This is important not simply in arguing for the validity of critical geopolitics but really any critical geography. The 'critical' adjective has come to be synonymous with poststructuralism, post-modernism, post-colonialism, and feminist critiques of grand theory. Critical Geopolitics, in the words of Ó Tuathail and Dalby, is "'making strange" the

\footnotetext{
${ }^{14}$ See Ó Tuathail and Agnew, 'Geopolitics and Discourse' and G. Ó Tuathail and S. Dalby, 'Introduction: Rethinking Geopolitics: Towards A Critical Geopolitics', G. Ó Tuathail and S. Simon Dalby (ed.) Rethinking Geopolitics (London: Routledge, 1998) p.5. 'Formal geopolitics' would be the focus of Ó Tuathail's (1996) work in critiquing Samuel Huntington's 'Clash of Civilizations' thesis as well as the classical geopoliticians like Halford Mackinder. For an example of 'Popular geopolitics' see, Sharp's analysis of Reader's Digest is the quintessential example of popular geopolitics.
} 
taken-for-granted political constructions of space, and making explicit struggles over the politics of place ${ }^{15}$ Critical geopolitics, in this sense, opens up geographies rather than closes them off. The question most often posed in this respect was how geopolitics or imagined regions known as states were considered neutral, impartial, and natural and thus not under the radar of critique: geography was taken-for-granted.

\section{Figure 5}

\section{Ó TUATHAIL'S GEOPOLITICAL DIAGRAM}

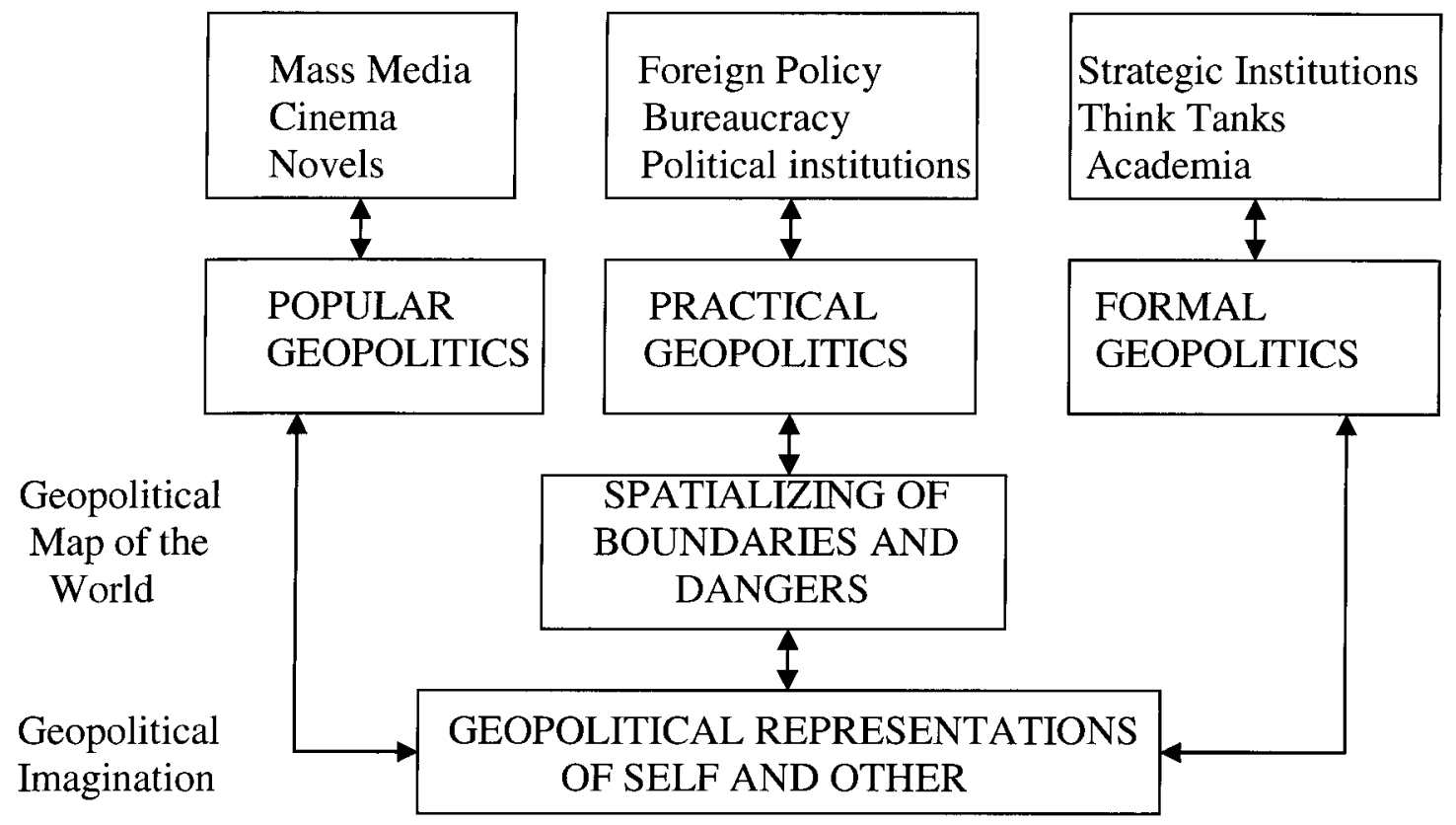

Sources: Ó Tuathail and Dalby, 1998

The critiques took many forms in terms of the theoretical tools used to deconstruct discourse, text, context, structure, culture, et cetera, all of which ultimately look for how these geographies were constructed and many, like the Marxist critiques, ask why? Certainly a political economy of geopolitics exists. Material accumulation 'provide[s] some theoretical and empirical opportunities for grounding elite geopolitical reasoning

${ }^{15}$ G. Ó Tuathail and S. Dalby 'Critical Geopolitics: Unfolding for Thought in Geography and Global Politics', Environment and Planning D: Society and Space. 12 (1994) p.513. 
within the material circumstances that elites sought to reproduce'. ${ }^{16}$ However, Marxist critiques boil down the reasons for 'geo-graphing' to material gains. For instance, the War in/on Iraq would be firmly reduced to oil prospects and networks that would link the President of the United States and his staff to networks of businesses that gain from war and oil, like, for example, Haliburton. ${ }^{17}$ In other words, Marxists reduce humans to 'rational economic actors' without regard for human agency, culture-religion included - or other factors. ${ }^{18}$ In short, the Marxist tradition is indeed a radical and critical one, particularly World Systems Theory that looked past states as the primary actors, but still Marxism is economistic, reductionist, deterministic toward the object of material production and consumption, and thus Marxism when criticizing assumptions makes its own assumptions about the way the world really is. ${ }^{19}$

Humanism in geography sought a break with Marxism precisely because of the reasons alluded to above: it was reductionist. Humanists, of course, sought to return to the subject 'human agency', something lost in positivism and Marxism. After a short survey of the history of humanism in geography, Ley and Samuels (1978) saw a lack of consensus in research and a blatant disregard for self-reflexive or double hermeneutic partiality in relation to cognitive components of human experience. Hermeneutics addresses the imbalance created by the positivist focus on the object by focusing on the self-understanding of the subject. But this too can be critiqued because Humanism still

${ }^{16}$ K. Dodds and J. Sidaway, 'Locating Critical Geopolitics', Environment and Planning D: Society and Space. 12 (1994) p.519.

${ }^{17}$ See D. Harvey, The New Imperialism (New York: Oxford, 2003).

${ }^{18}$ D. Ley and M. Samuels, 'Introduction: Contexts of Modern Humanism in Geography', in D. Ley and M. Samuels (eds.) Humanistic Geography (Chicago: Maroufa, 1978) p.11-12; See also S. Dalby 'Writing Critical Geopolitics: Campbell, Ó Tuathail, Reynolds, and Dissident Scepticism', Political Geography. 15/6-7 (1996) pp.655-660.

19 See, P. Taylor, Political Geography: World-Economy Nation-State and Locality (Essex: Longman, 1985). 
accepts the arbitrary use of 'subject' and the 'object', even though they are historically constructed categories. ${ }^{20}$ Thus "facts are assumed to exist independent of the theories which construct the categories of facts'. ${ }^{21}$ Humanism is then critiqued by unveiling the privileged, sovereign author and the subject of authority. To use an example, the theory (subject) is not separate from reality (object), they are entwined; what we see and how we interpret reality is filtered through the theory we believe to represent or make sense of reality. It must be accepted that theory, and hence reality, are human constructions: people interpret the world in different ways. ${ }^{22}$

Regional geography and more specifically the 'regional monographs' of the French school led by Paul Vidal de la Blache has seen a resurgence in geographical inquiry. The idea of regions overlapping each other as opposed to fitting neatly together like puzzle pieces mirrors many contemporary critical geographers now calling for a change in the idea of the state as a contiguous and universal foundation from which to study the world. De la Blache's conceptions of 'possiblism', which allowed humans to react to the environment, has some similarities to critical theories, particularly that of post-structuralism or constructivism, in allowing for a multiplicity of variables to be considered. If geopolitical reasoning works to suppress the complex geographical 'realities' of spaces in favour of controllable abstractions, the regional French maps captured not an abstract essence but actually described the complexity of geographical spaces.

This is distinct from the German and American regional schools that were associated with environmental determinism, though the American school relaxed this

\footnotetext{
${ }^{20}$ Dalby, 'Critical Geopolitics'.

${ }^{21}$ Ibid, p. 265.

${ }^{22}$ Ibid.
} 
determinism in allowing for human agency with the onset of the ideas from such major geographers as Richard Hartshorne and Carl Sauer. Certainly these geographies are not compatible with a Critical Geopolitics for several reasons. First, the bounded spaces of the 'regions' that fit together seamlessly, at least as far as the German school was concerned, echoes Realism in IR as differentiated and bounded spaces, thus determining the inside and outside of assumed-to-be homogeneous spaces without consideration for migration of people and culture. Second, and a corollary of the first point, are the generalized 'geo-graphs' interpreted by the regional geographer. It is these 'hard truths' and 'irrevocable facts' that nature could be flawlessly represented, something Critical Geopolitics is critical of. ${ }^{23}$

The 'posty' literature in IR (by 'posty' is meant, post-structuralism, postmodernism, and post-colonialism), beginning in the early 1980s, questioned the assumptions addressed above and took on a project of deconstructing many of the 'commonsense' geographies used in foreign policy. Post-Marxism is sceptical of creating a single coherent system that centres subject debate and is interested in the way in which post-structuralism can reformulate history: one that challenges classical Marxism and the utopian end. The Borderlines book series edited by David Campbell and Michael J. Shapiro, which started in 1995 has published over twenty-nine books-many of which are written by geographers - and is attempting to debunk these naturalized geographies. It was, for the most part, Dalby who was one of the seminal geographers to incorporate the 'posty' theory emerging from IR and incorporate it into his own political geography in

\footnotetext{
${ }^{23}$ Dodds and Sidaway, 'Locating Critical Geopolitics', p.519.
} 
the late $1980 \mathrm{~s} .{ }^{24}$ His work, in combination with the work of Ó Tuathail, would come to be termed Critical Geopolitics.

Ó Tuathail notes that one can be critical of geopolitics but still be a geopolitician; but one cannot be a post-structuralist and a geopolitician. ${ }^{25}$ The post-structuralist can not use his/her tools to 'geo-graph', the role of the post-structuralist is to find how and why, and under what historical circumstances these 'geo-graphs' were imagined. ${ }^{26}$ If the purpose of post-structuralist theory is to challenge the use of power defined in identifiable and universal structures, then it does not speak truth to power and thus, does not 're-geograph' 'reality'; rather it speaks critically to the 'truths' power uses. In a way, Dalby's Creating the Second Cold War (1990) is guilty of a reductionist reading, which is precisely what Dalby was trying to distance himself from, by 'asking questions about the production of questions'. ${ }^{27}$ The identity politics narrative emphasized by both Dalby and Campbell, has itself become the 'formulaic reading strategy' in deciphering foreign policy texts. ${ }^{28}$ In other words, just as geopolitics and sovereignty had become the be-alland-end-all analysis scripts, so too has attributing foreign policy to identity politics limited other forms of analysis. This is also to miss a fundamental point of research, that not all Othering is essentially spatial; threats from within cannot simply be banished by exclusion. Admittedly, Dalby writes that critical geopolitics cannot escape these discursive reality-making processes and practices but it can help to recognize 'how we

\footnotetext{
${ }^{24}$ See, Dalby, 'Geopolitical Discourse'.

${ }^{25}$ Ó Tuathail, Critical Geopolitics, 142.

${ }^{26}$ Dalby, 'Writing Critical Geopolitics', p.656.

${ }^{27}$ Dalby, 'Critical Geopolitics', p.269.

${ }^{28}$ Ó Tuathail, Critical Geopolitics, p.182; G. Ó Tuathail, 'The Patterned Mess of History and the Writing of Critical Geopolitics: A Response to Dalby', Political Geography 15/6-7 (1996) p.664.
} 
describe and discursively construct social reality and inescapable political acts' ${ }^{29}$ This point is also made by Ó Tuathail: 'Critical readings of geopolitics are themselves enmeshed in relations of power and can congeal geography and politics (geo-politics) into new forms of geo-power'. ${ }^{30}$

However, how then can this thesis speak critically about the 'truths' of premillennialism as a belief system? Dijkink puts it this way:

Critical geopolitics and post-structuralism still cling (often without admitting it) to the idea that there are unfounded representations (narratives) versus ways to remain more faithful to reality. The fusion of religion and geopolitics is in this perspective an objectionable way of deceiving people. Critical geopolitics ignores the fact that we cannot live without belief. A similar blind spot underlies the directive that we should live rational[ly]. ${ }^{31}$

Dijkink's attempt to provide a 'religeopolites' research agenda is commendable in many ways, particularly with respect to his observation that religious analysis is lacking in geopolitical literature. However, religion in this thesis is not privileged over other ideological and cultural belief systems. Religion is written of as outside theology and not in a separate realm but inside a political struggle of knowledge/power. However, this thesis is not 'critical' of Christianity; it is rather critical of a particular view of history and theory called premillennial dispensationalism: a theory that makes troubling geopolitical expressions of the world that have political and military implications in the world outside its disciplinary borders. This, rather than being overtly critical, shows the reasoning practices that enable these particular Apocalyptic geopolitics.

\footnotetext{
${ }^{29}$ S. Dalby, Creating the Second Cold War: The Discourse of Politics (New York: Guilford 1990) p.171.

${ }^{30}$ Ó Tuathail, Critical Geopolitics, p. 142.

${ }^{31}$ G. Dijkink, 'When Geopolitics and Religion Fuse', presented at the $55^{\text {th }}$ Pan-European International Relations Conference, in The Hague (Sept. 2004) p.4.
} 


\section{Apocalyptic Geopolitics}

This research does not neatly fit into 'Formal/Practical/Popular' taxonomy. It would fit best into Formal geopolitics because theology and eschatology could be considered the scholarship of religion. However this research could also fit into Popular forms of geopolitics because religion is inextricably fused to cultural knowledge. As mentioned, Hitchcock's textual style fits much more clearly in the category of 'tabloid geopolitics'. Lari Nyroos' term 'religeopolitics' and Stephen Graham's term 'vertical geopolitics' will not be used because both are heavily associated with the use of religion to justify state politics, where this study analyzes specifically how religion has used, created, and interpreted geopolitics. ${ }^{32}$ To remove the confusion here and to make a more descriptive term, the designation 'Apocalyptic geopolitics' is proposed. ${ }^{33}$ Therefore precision is the primary concern. Such a term could open up new opportunities for analysis with other forms of Christianity, or Judaism, or Buddhism, or any other religion that geo-graphs. This does not mean that the 'religious-map' is objective and separate from other political spheres, or in history and geography. Nor does this mean that apocalyptic geopolitics is divorced from state politics (certainly it is intimately informed by it). Rather, it seeks to make a distinction between using 'religion in state politics' and 'religion as geopolitics'. Furthermore, it does not mean that different aspects of each category of geopolitics do not inform each other.

\footnotetext{
${ }^{32}$ L. Nyroos, 'Religeopolitics: Dissent Geopolitics and the "Fundamentalism" of Hamas and Kach', Geopolitics 6/3 (2001) pp.135-157 and S. Graham, 'Vertical Geopolitics: Baghdad and After' Antipode $36 / 1$ (2003) pp.12-23.

${ }^{33}$ I hesitate doing so because of the complexity associated with the vernacular already present in critical geopolitics but is done here to avoid widening the definition of both 'religeopolitics' and 'vertical geopolitics'.
} 
What is termed 'Apocalyptic geopolitics' in the title of this thesis and above can be defined as geopolitics not limited to millennial or religious discourse but rather as part of the broader construction of geopolitics whereby geopolitics is used to describe an ideology of major societal change. In other words, the maps drawn are visual representations of future verb tenses. For example, the fear of communism was a fear of the end of the capitalist world to many Cold War geopoliticians; capitalism can be seen as a form of apocalyptic thought to Marxists, environmentalists and many others. ${ }^{34}$ For this thesis, the category Apocalyptic geopolitics is useful as a comparative moniker or subject; in comparing secular geopolitical constructions with religious forms, as is done throughout this thesis, a weaving of the commonality between geopolitical forms is made possible both in defining Hitchcock's work as geopolitical, and therefore, allows this thesis to engage in religious discourse as human made thus removing it from the 'god trick' or more aptly what Matthew Sparke, implicitly in reference to the Rapture, terms the 'Jesus trick'. ${ }^{35}$ A collection of work on the topic of Apocalyptic geopolitics could be very useful in geopolitical analysis, particularly in explaining the reasoning strategies of certain forms of geopolitics. However, for the sake of simplicity, Apocalyptic geopolitics will refer to apocalyptic 'religion as geopolitics' and 'secular geopolitics' will denote all others not explicitly expressed as 'religious'.

\footnotetext{
${ }^{34}$ There were many Cold War movies depicting maps with red arrows or blood flowing from the USSR depicting the Red Army's invasion of Europe. See Ó Tuathail, Critical Geopolitics. For a satirized example, see the movie Canadian Bacon. In the movie as an attempt to amass popular support for an American war against Canada, a map of North America is shown on television with maple syrup oozing across the Canada-US border.

${ }^{35}$ M. Sparke, In the Space of Theory: Postfoundational Geographies of the Nation-State (Minneapolis: University of Minnesota Press, 2005) p. 308.
} 
Certainly what has been termed 'secular geopolitics' above could be argued a false or inaccurate label. ${ }^{36}$ At some level all geopolitical constructions could be argued as being religiously informed. Therefore, religion might be seen as an intrinsic cultural factor in geopolitical imaginations. Examples of Formal geopolitics using religion would include Slobodan Milosevic using the Serbian Orthodox Church to gain favour among followers. However, it is well known that Milosevic was not motivated by religious zeal. ${ }^{37}$ As Gregory notes, Saddam Hussein also concealed his secular designs under an Islamic guise. ${ }^{38}$ Furthermore, during the Iranian Revolution, several Iranians believed that Ayatullah Ruhollah Khumayni, the spiritual and theoretical head of the Revolution, was the Hidden Imam who would cleanse the world of evil through an Islamic apocalypse. Still lesser known, Adolf Hitler also used Christian meritocratic language to justify his own means; for example, in Mein Kampf, he wrote '...I am convinced that I am acting as the agent of our Creator. By fighting off the Jews, I am doing the Lord's work' ${ }^{39}$ These examples exhibit a clear religious influence, though it is not clear whether any of these leaders actually believed that they were somehow doing the work of Allah or God. Certainly religion was used in specific contexts to appeal to (potential) religious or political followers.

Religious leaders and movements also have influence in what might be termed 'secular geopolitics'. Zionism (and its tacit acceptance by the United States as evidenced in its staunch support of Israel) and the Jesuit order in European geopolitics as Ó Tuathail

\footnotetext{
${ }^{36}$ On challenging modernity as 'secular', see Asad, T., Formulations of the Secular: Christianity, Islam, Modernity (Stanford: Stanford University Press, 2003).

${ }^{37}$ M. A. Sells, The Bridge Betrayed: Religions and Genocide in Bosnia (Berkeley, CA: University of California Press, 1996) p.25.

${ }^{38}$ D. Gregory, The Colonial Present: Afghanistan, Palestine, Iraq (Malden, MA: Blackwell, 2004) p.161.

${ }^{39}$ Quoted in K. Burke, 'The Rhetoric of Hitler's "Battle", in M. J. Shapiro (eds.) Politics and Language (New York: New York University Press, 1984) p.63.
} 
(2000) has pointed out, with the influence Jesuit Edmund Walsh (1885-1956) had on U.S. foreign policy and geopolitics. ${ }^{40}$ Well known general implications can be felt by various Popes in Rome and the biblical Great Commission which were used to justify the West's colonial actions and is typified by aggressive cultural transformations that accompanied that penetration. ${ }^{41}$ There are of course non-Abrahamic examples including some Chinese Emperors seeing themselves as the ordained centre of the Earth. ${ }^{42}$ Consistent with all of these geopolitical expressions is a godlike gaze and a godlike positioning on theatrum mundi.

There are of course varying forms of apocalyptic geopolitics that could have been studied here, particularly from the Abrahamic religions (Judaism, Christianity and Islam). In much the same way (and as Appleby (2003) makes clear) radical Muslims blame 'failures,' such as the abandonment of Islam as the basis of an orderly society on Western colonial powers; such a decline is marred in the West's 'apostasy' and an apocalyptic yearning for a better, more Islamic world. ${ }^{43}$ Like the dispensations (or periods) of premillennalism, the return of the twelfth Imam is preceded by a failure by humankind to bring an Islamic utopia to Earth. ${ }^{44}$ Shiite Muslims expect the world to drown in evil brought on most forcefully by their 'evil' enemy Other. These apocalyptic (both Christian and Islamic) stories are similar: both feel there is a period of crisis where the end is near when God will punish those evil forces and save God's obedient and believing children

\footnotetext{
${ }^{40}$ Walsh was founder and dean of the Edmund A. Walsh School of Foreign Service at Georgetown University and was known for his anti-communist leanings.

${ }^{41}$ The Great Commission refers to marching orders to Christianize the world (Matt. 28: 16-20).

${ }^{42}$ See S. Cammann 'The Magic Square of Three in Old Chinese Philosophy and Religion', History of Religions 1 (1961) p.60-64. Emperors wore yellow robes because yellow represented the centre of the earth, see V. M. Garrett, Chinese Dragon Robes (Hong Kong: Oxford University Press, 1998) p.2-10.

${ }^{43}$ R. S. Appleby, 'Fundamentalism and Nationalist Religious Movements', in J. Agnew, K. Mitchell and G.

Ó Tuathail (eds.) A Companion to Political Geography (Malden, MA: Blackwell, 2003) p.383.

${ }^{44}$ Ibid.
} 
finalized in the creation of a purged world. Both Sunnis and Shiites, as a general rule, believe in an eventual saviour of humanity. While they differ in areas of epistemology, particularly with the existence of the twelfth Imam (Mahdi), both believe that God will bring absolute peace and justice throughout the world by establishing Islam as the global religion. Shaykh Muhammad Hussayn Fadlallah, who was the spiritual leader of Hezbollah, for example, believed Islam was to transcend state borders as an allencompassing Islamic state embodying umma (or worldwide Islamic community). ${ }^{45}$ This was influenced by strong apocalyptic beliefs of the returning Messiah who would sweep the globe in battle to triumph Islam. One of Fadlallah's disciples predicted, 'The divine state of justice realized on part of this earth will not remain confined within geographic borders' the achievement of this Islamic world will lead to the return of Mahdi, 'who will create the state of Islam on earth'. ${ }^{46}$

Jewish apocalyptic theology would also be of interest as an apocalyptic geopolitics particularly when compared to Christian versions. Yitzhak Rabin, for example, was assassinated by a 'good Jew' (a religious Jew), who believed there is a holy deed to Israel and not a political one. The assassin expected Rabin's death to quell the peace process and therefore hasten the apocalypse. ${ }^{47}$ In Jerusalem Betrayed (1997), Mike Evans describes the peace process from a Jewish apocalyptic perspective as 'an international plot to steal Jerusalem from the Jews...behind the international cast of collaborators is a master conspirator who is directing the play' as the yet unrevealed

\footnotetext{
${ }^{45}$ A. M. H. F. Allah, 'Islam and Violence in Political Reality', Middle East Insight. 4/4-5 (1986) pp.4-13 quoted in ibid.

${ }_{46}^{46}$ Allah, 'Islam and Violence in Political Reality', quoted in ibid.

${ }^{47}$ G. Gorenberg, The End of Days: Fundimentalism and the Struggle for the Temple Mount (Oxford: Oxford University Press, 2000) p.165-166.
} 
Antichrist. ${ }^{48}$ Yoel Lerner, a religious Jew and follower of Gershon Solomon, was twice convicted for trying to blow up Al-Aqsa Mosque to help bring closer the coming apocalypse. $^{49}$

Beyond Abrahamic religions, the Navajo of the American Southwest believed the frontiers-people were a long awaited sign that the world would soon come to an end. One Navajo man, Wovoka, foresaw in a dream that the White people would come and destroy their hunting grounds and the environment, leading to the apocalypse; but not before the Navajo, and they alone, would be 'Raptured' safely into the sky while all others would be 'buried alive by earthquakes and landslides, with the survivors transformed into small fishes in the river'. ${ }^{50}$ For the Navajo, the apocalypse was the rejection of the colonized landscape as the final telos of history. It was also a security that restoration and renewal was on the horizon. Therefore, embracing environmental degradation promised that a 'Second History' was soon to come. ${ }^{51}$

\footnotetext{
${ }^{48}$ M. Evans, Jerusalem Betrayed: Ancient Prophecy and Modern Conspiracy Collide in the Holy City (Dallas: Word Publishing, 1997) quoted in ibid, p.167.

${ }^{49}$ Gorenberg, The End of Days, p. 120.

${ }^{50}$ M. Davis, Dead Cities: And Other Tales (New York: The New Press, 2002) pp.27-29.

${ }^{51}$ Ibid. See also, F. L. Borchardt, Doomsday Speculation as a Strategy of Persuasion: A Study of Apocalypticism as Rhetoric (Lewiston: The Edwin Mellon Press, 1990) p.41.
} 


\section{Chapter 2:}

Strategies Toward Transcendence: Theory and Method $\mid$

Mark Hitchcock's apocalyptic geopolitics are explicit and implicit forms of theatre, from the implicit umbrella of the Rapture that promises transcendence from evil to his analogies of the End Time to 'stages', 'scenes', 'sets', and 'plays'. This chapter explores how these analogies and metaphors of theatre are to be read and stripped of their ostensibly ordained resolution of the way the world really is. The first section defines how 'performance', 'performativity' and 'theatre' are used and understood in this thesis. The second section outlines the method of discourse analysis to be undertaken. It will explore how Hitchcock will be read. A Foucauldian analysis is applied not because it is en vogue but rather because it contains the tools to pry off the commonsense cover of geopolitics to reveal a pool of assumptions and strategies used to construct a particular geopolitics. The third section of this chapter, using Foucault's work on 'transcendence/transgression' and de Certeau's concepts of 'strategies/tactics', explores the latter, implicit form, from the position that privileges earthly transgression over the theatre of transcendent escape. ${ }^{1}$ Transcendence and transgression are diametric opposites. The transgressive engages with the physical world and the transcendent is passive and escapist. It is the view of this thesis that the transcendence from perceived repression, toward a heaven of liberation, obviates the ability to think of a better world.

\footnotetext{
${ }^{1}$ M. Foucault, 'A Preface to Transgression' in D. Bouchard (eds.) Language, Counter- Memory, Practice D. Bouchard and S. Simon (trans.) (Ithaca: Cornell University Press, 1977); M. de Certeau, The Practice of Everyday Life (Berkley: University of Califonia, 1984).
} 
This thesis could have used the works of Marx, Nietzsche or Deleuze to work through the ideas of theatre, transcendence, and the End Time. Although Marx was virtually silent on religion, this is not the reason he was not chosen. Certainly one could formulate a theory on theatre as a form of capitalist production, a form of labour as some have. ${ }^{2}$ One could also have used the work of Nietzsche and his abhorrence of Christianity and claims to a world free of the structuralist chains of religion. ${ }^{3}$ Nietzsche asked in relation to the apocalypse, "what did God give man revelation for?" ${ }^{4}$ Nietzsche means here, why did we give ourselves this foretelling of history? His answer would be that religion is taken to be our existential center but is nothing more than an 'empty void' we continually, yet unsuccessfully, strive to fill through our attempts at metaphysical, or apocalyptic, closure. ${ }^{5}$ Nietzsche put socialism in the same category as Apocalyptic Christianity because he despised the telic discourses associated with both. However, and quite ironically, both Marx and Nietzsche make their own universal prognostications and teleologies of world history. ${ }^{6}$ Nietzsche saw cultural nihilism as the coming apocalypse; using Revelation as a template, he writes: "for when truth steps into battle with the lie of millennia we shall have convulsions, as earthquake spasm, a transposition of valley and

\footnotetext{
${ }^{2}$ See J. L. Beller, 'Capital/Cinema', in E. Kaufman and K. J. Heller (ed) Deleuze and Guattari: New Mappings in Politics, Philosophy, and Culture (Minneapolis: University of Minnesota Press, 1998) p.77-95. ${ }^{3}$ See F. Nietzsche, Human, All Too Human. Marion Faber (Trans.) (Lincoln: University of Nebraska Press, 1996 [Originally published in 1878]).

${ }^{4}$ F. Nietzsche, 'The Antichrist', in W. Kaufman (ed) The Portable Nietzsche (London: Penguin, 1982 [Originally published in 1895]) p.641. (This book is far from 'portable'!)

${ }^{5}$ In Nietzsche's words the human search for truth will drive us further into void, nothingness, and emptiness: 'man would rather will the void, than void the will'. See T. B. Strong, 'Language and Nihilism: Nietzsche's Critique of Epistemology', in M. J. Shapiro (ed.), Politics and Language (New York: New York University Press 1984) p.102. See also Mircea Eliade's classic text, The Sacred and the Profane: The Nature of Religion (New York: Hardcourt, 1987 [Originally published in 1957]), like Nietzsche, he claims that even in the increasingly secular modern world we still unconsciously nourished/haunted by the 'presence' of the sacred.

${ }^{6}$ Jacques Derrida, was ambiguous toward religion though as Nietzsche and Marx have been drawn above, was an advocate of his own religion of 'Negative theology'. For Derrida contrasted with the work of Emmanuel Levinas, see J. D. Caputo, The Prayers and Tears of Jacques Derrida: Religion without Religion (Bloomington: Indiana University Press, 1997).
} 
mountain such as has never been dreamed of ${ }^{7}$ This thesis does not take purchase in telic discourse nor such nihilism, rather it will transgress with cultural imperialism.

Gilles Deleuze, however, offers a very interesting and applicable project, one that challenges the transcendent in favour of the immanent. That is, Deleuze would challenge the transcendent character of the Rapture and its enabling abilities for representations, though he would do so by offering a theory of non-representation, and therefore, in many ways a solution to premillennialism as geopolitics. For example, Deleuze's books on Cinema, see theatre as both a strategy for representation and also a tactic toward nonrepresentational discourses. ${ }^{8}$ Privileging the latter, Deleuze saw theatre and cinema as a mode in which ideas of transgression are invented that challenge the status-quo. ${ }^{9}$ It is foundational and also post-foundational. Deleuzian theories on cinema are predominantly, however, the inspiration for non-representational theory. This thesis sees theatre and cinema as the result of performance and in itself a representation and a preconception as to the way one acts in the play and as an audience member. Therefore, Deleuze is in may ways the antithesis of the argument here though at the same time the goal. The Deleuzian project is to lay out the transcendent in such a way that it is made visible as immanent. This thesis, however, is not concerned with the 'ontological thirst' 10 for "creating systems for living in the vastness"11 of non-representational and

\footnotetext{
${ }^{7}$ F. Nietzsche, Ecce Homo. R. J. Hollingdale (trans) (London: Penguin, 1979 [Originally published in 1888]) p.127.

${ }^{8}$ On Cinema see G. Deleuze, Cinema 1: The Movement-Image. H. Tomlinson and B. Habberjam (trans) (Minneapolis: University of Minnesota Press, 1986) and G. Deleuze, Cinema 2: The Time-Image. H. Tomlinson and R. Galeta (trans) (Minneapolis: University of Minnesota Press, 1989). On nonrepresentational theory, see G. Deleuze and F. Guattari, A Thousand Plateaus. B. Massumi (trans) (Minneapolis: University of Minnesota Press, 1987).

${ }^{9}$ E. Kaufman and K. J. Heller, Deleuze and Guattari: New Mappings in Politics, Philosophy, and Culture (Minneapolis: University of Minnesota Press, 1998) p.8.

${ }^{10}$ Eliade, The Sacred and the Profane p.64.

${ }^{11}$ M. Rose, 'Reembracing Metaphysics', Environment and Planning A 36/3 (2004), p.465.
} 
psychoanalytically informed social theory (though it is explored briefly in the conclusion). Rather it is concerned with the discursive reasoning practices/strategies that make Hitchcock's speciously apolitical and biblical geopolitics possible. Hitchcock's work is then seen as a political power/knowledge relationship that manifests itself in the representations of space. Using Foucault's work on genealogy, Hitchcock's geopolitics are then re-politicised by tracing his reasoning strategies.

\section{Performance and Performativity}

Of primary concern in this thesis is Hitchcock's theatre metaphor as a strategy towards making-visible his apocalyptic geopolitics. The popular concepts of 'performance and performativity' in geography are also of interest, but theatre, understood here as the result of the performative rehearsal of the premillennial doctrine, is the main focus. Gregson and Rose define performance and performativity thus: 'performance-what individual subjects do, say, "act-out"-performativity-the citational practices which reproduce... discourse and which enable and discipline subjects and their performancesare intrinsically connected, through the saturation of performances with power'. ${ }^{12}$ As Gregson and Rose point out, spaces are also performative. Beyond social relations, space also needs to be thought of as being brought into being through performance. In other words, spaces do not pre-exist their performance; spaces are performitive of power relations: they are an articulation of power. ${ }^{13}$ In this thesis, these performed spaces are Hitchcock's geopolitics which he elucidates through dramaturgical metaphors of 'stageEarth'.

\footnotetext{
${ }^{12}$ Gregson, and Rose. 'Taking Butler Elsewhere', p.434.

${ }^{13}$ Ibid, p.441. See also, C. Nash, 'Progress Reports, Performativity in Practice: Some Recent Work in Cultural Geography', Progress in Human Geography 24/4 (2000) pp.653-664
} 
'Performativity', in this thesis, however, is understood as the establishment of practiced epistemological scripts, (in this case from the Bible, which inculcate norms), that provides ways of knowing and acting within the world. It is the actors, or believers, performing their signifying function. 'Performance' then, is the political bubbling up of performativity; that singular moment made possible by the rehearsal of religious acts, norms and strategies like sermons or political speeches; it is how Western society has come to understand and define politics. The 'theatre' is the 'chapel' or 'church' and the 'stage' is the pulpit before the Rapture. However, after the Rapture the 'theatre' is Heaven and Earth and the 'stage' is the Middle East, from which the performance (Armageddon) is given. The theatre is then made possible through performativity or rehearsal of the way to act in, conceive of, and understand the theatre as an audience member separated geographically from the stage but not separated from the way the play is acted out; the act must appeal to the audience and is therefore created with the audience in mind. This particularity is an informed subjectivity that creates the 'self' as an audience member and also the performance. Because, what is a performance if no one is there to watch? Some performances might be seen as unacceptable in this theatre. It would exceed acceptable parameters and would be out-of-place for his audience's premillennial discourse. For the reader of Hitchcock, the ticket is the book itself with a price tag attached to it. The scripts or words that Hitchcock as playwright types on the page are a condensed dictation of the reality written of in the Bible. It is then the theatre which, in the analysis of Hitchcock's work, is the result of the performance/performative complex. The stage is the geopolitical lines drawn on the world and the seats, following the Rapture, are in Heaven with special reserved box seats for the playwrights. If we 
understand Hitchcock's geopolitics as performed in and through social and political interaction, his geopolitics can be de-naturalized and de-deifyied. The genealogy of the strategies of how Hitchcock is able to divide the world is the focus of this thesis, specifically how the pessimistic view of the omnipotence of evil in the world, needs a mechanism or strategy of escape: the Rapture provides that escape.

Performance in this thesis is 'staged', and played out for spectators behind the scenes and in the auditorium. They are seen as the product of unconscious and conscious acts. However, Butler, using the work of Austin, rejects the theatrical notions of agency and subjectivity. She rather saw the social agent as not existing prior to the production of space. In other words, Butler saw the subject as acting in order to exist rather than existing in order to act. In Nietzsche's words, from which Butler takes her cue, 'there is no "being" behind doing, acting, becoming; the 'doer' is merely a fiction imposed on the doing-the doing itself is everything'. ${ }^{14}$ Hitchcock is written as both the influencer and the influenced, however. He 'acts in order to exist' in the sense that the premillennialism cannot exist unless it is performed; but Hitchcock also 'exists in order to act' as one of God's geographers. The conceptualization of the subject-Hitchcock-has agency, subjectivity and has political effects. This is not to say that Hitchcock is one remove from other premillennialists (he is influenced by other performed spaces), however, his performances are heard louder than, say, someone in his congregation. Agency must be granted to Hitchcock in order for the rationality and strategy behind the performance to be explored.

\footnotetext{
${ }^{14}$ F. Nietzsche, On the Genealogy of Morals, p.5 cited in S. Salih (ed), 'Introduction', in The Judith Butler Reader (Malden, MA: Blackwell, 2004) p.6. For Butler's words, see J. Butler, Gender Trouble: Feminism and the Subversion of Identity (New York: Routledge, 1990) p. 25.
} 


\section{Method: Discourse, Foucault, and Strategy}

Simon Dalby writes of Robert Cox's distinction between problem solving theory and critical theory: 'problem solving theory is supportive of the status quo, whereas critical thinking asks more fundamental questions of how power works and might be challenged'. ${ }^{15}$ By asking 'how' one does not concern oneself with right or wrong 'because we are enmeshed in [different] cultural and historical circumstances' but rather how is concerned with discourse-in this case the premillennialist discourse-through words, phrases, and the material world from which premillennial 'reality' is constructed. ${ }^{16}$ The premillennial discourse is predominantly influenced by biblical exegeses and political events. The goal of this research is to investigate the politicalreligious power nexus required to formulate normative biblical geographies for those premillennial 'believers'. That is, those taken-for-granted geographies Hitchcock 'imagines' yet also makes normative to his direct followers and also those indirect recipients of this knowledge in the cultural and political landscape of the United States.

This analysis is 'post'structuralist in that it will study 'discourses' rather than working within Saussure's structuralist 'language system'. ${ }^{17}$ The difference is that the former recognizes that networks of words and phrases change, while the latter assumes them to be fixed and always representative of a single discursive and tautological 'reality'. Discourse is understood here to be changing and competing with other discourses and influenced by non-discursive practices. A discourse is not a well bounded

\footnotetext{
15 S. Dalby, 'Critical Geopolitics: Discourse, Difference, and Dissent', Environment and Planning D: Society and Space. 9 (1991) p.266 emphasis added; See also, R. Cox, 'Social Forces, States and World Orders' in R. Keohane (ed.) Neorealism and Its Critics, (New York: Columbia University Press, 1986). 16 Ibid.

${ }^{17}$ L. Phillips and M. Jorgenson, Discourse Analysis as Theory and Method (London: Sage, 2002) p.9.
} 
space; it is rather correlated with many discursive formations. This thesis will then describe 'clusters of relationships'; relationships that are interconnected and influenced in a system by the social relations and power politics of the time. It is for this reason that Hitchcock’s geopolitics are compared to earlier premillennial geopolitics.

Discourses are not simply texts: they are the set of capabilities people have to construct the world. Discourses are sets of 'rules and representations' that readers, writers and listeners can abstract from to construct their own worlds. ${ }^{18}$ Representations are crucial in describing discursive practices enabled by discourses. Taken from Foucault's later work on 'Genealogy', discourses are tactical elements or blocks operating in the field of force relations. ${ }^{19}$ They are the means to advance their interests and projects. This thesis will explore the political discursive reasoning strategies that are excluded through an exercise that privileges the Bible as the primary source of knowledge about the world. How premillennialists represent the geographies of the world will determine what can be justified 'because reality could be represented in particular ways political decisions could be taken' and justifications understood. ${ }^{20}$ In terms of a premillennial discourse, it is predominantly influenced by international politics. This thesis will investigate the knowledge/power relations and strategies required to normalize this transposition which both secures the discourse of Hitchcock's geopolitics and the idea of premillennialism. Like maps that preserve scale, for example equal area maps, the premillennial view is an orthogonal one that disciplines the vectors connecting discursive statements, and between these statements and the geopolitics they write. However, as is shown below, these

\footnotetext{
${ }^{18}$ G. Ó Tuathail and J. Agnew, 'Geopolitics and Discourse: Practical Geopolitical Reasoning in American Foreign Policy', Political Geography 11/2 (1992) p.194.

${ }^{19}$ D. Howarth, Discourse (Buckingham: Open University Press, 2000) p.67.

${ }^{20}$ S. Dalby, 'Writing Critical Geopolitics: Campbell, Ó Tuathail, Reynolds, and Dissident Scepticism', Political Geography 15/6-7 (1996) p.658.
} 
vectors of faith and truth are at times distorted between biblical interpretation and the maps that express them. That is, as American political history moves to define new enemies, so too does premillennialism by realigning the linkages between biblical text with American foreign policy. If we understand premillennialism as a practice of normalisation and control then the apocalyptic signs in the world are a method of control, an evidence the end is near, which in many cases is the foundation of premillennial faith-'to be in the know.'

To Foucault, 'statements' are not merely words or utterances, they are claims to 'truth'. ${ }^{21}$ This analysis will find and analyse discursive processes that make intelligible 'true' or 'false' representations. This thesis is concerned with sets of statements taken to be serious claims to truth and will describe the appearance, types and relations between statements, as well as their regulated historical transformation. An example of a claim to truth, is a scientist who makes claims about global warming by presenting plausible evidence and theories to justify her or his arguments. Hitchcock, and others like him, presents a theory of geography that is justified and evidenced in the Bible; the evidence simply needs to be interpreted not unlike a scientific statement or scientific research. Apocalyptic discourse and 'jingoistic' politics make the science of premillennialism.

A Foucauldian discourse analysis examines discourses as though they were competing for the ability to claim truth through a knowledge/power 'double helix'. ${ }^{22}$ In this case, the Bible competes with foreign policy. Power makes the 'social' possible by creating common knowledge that can be socially understood. The very position of 'Geographer' presupposes the use of geographical techniques or strategies by which

\footnotetext{
${ }^{21}$ Howarth, Discourse, p.79.

${ }^{22}$ Phillips and Jorgensen, Discourse Analysis as Theory and Method, p.13.
} 
objects are arranged, presented and projected. Representations of war in the Middle East are not congenital but rather power/knowledge relationships. For Foucault, "there is no power relation without the correlative constitution of a field of knowledge, nor any knowledge that does not presuppose and constitute at the same time power relations'.23 Knowledge, whether religious, political or both combined, is power; it has the power to move the world and make sense of it. ${ }^{24}$ Power and knowledge and space are then bound together, thus power/knowledge operates geopolitically through narratives, concepts and signifying practices. Dodds and Sidaway (1994) suggest that the exploration of the power/knowledge nexus is the most important aspect of critical geopolitics. ${ }^{25}$

Foucault saw religion as part of the practice used to order things. He presents religion outside theology and not in a separate realm outside culture, but inside a political struggle of knowledge/power. ${ }^{26}$ Therefore this thesis will attempt to bring premillennialism back into history and back into the immanent struggle of identity and subjectivity. Religion is a central part of the cultural conditions of knowledge-they are interconnected parts of each other. The religious power of premillennialism is seen as not completely separate from politics but rather informed by it; it is a knowledge practice that can not be studied separate from politics but can still be studied as interconnected discourse. That all environmental disasters, wars, and regional representations are preordained events set out in the Bible is a deeply political reading: all of these are epiphenomena that Christ will soon return.

\footnotetext{
${ }^{23}$ Quoted in Howarth, Discourse, p.77.

${ }^{24}$ G. Dijkink, 'When Geopolitics and Religion Fuse', presented at the $5^{\text {th }}$ Pan-European International Relations Conference, in The Hague (Sept. 2004) p.4.

${ }^{25}$ K. Dodds and J. Sidaway, 'Locating Critical Geopolitics', Environment and Planning D: Society and Space. 12 (1994) p.516

${ }^{26}$ J. Carrette, Michel Foucault: Religion and Culture (New York: Routledge, 1999) p.31.
} 


\section{Transcendence/Transgression, Strategy/Tactic}

This thesis weaves together Foucault's work on 'transcendence/transgression' with de Certeau's work on 'tactics/strategies'. ${ }^{27}$ It will use these theorists, not as a critique of the work of Hitchcock, but rather as a guide to write of Hitchcock. He is read as a strategy of escape from a material, earthly existence. This writing of Hitchcock also falls into the abyss of theatrics and representation —as author and auditor-as all writing can. Writing of social processes is a selective process attempting to re-enact the 'real' world like that of a play which exists to represent a particular, scaled down, vision of society. On the theatrics of writing, Gregson and Rose affirm, 'the execution of research projects, their writing, and their dissemination are supreme examples of academic performance and performativity'. ${ }^{28}$ The power of citation and reinscription, which produces and interprets, is a method of theatre-making: it is theatricality and a creative process. However, this thesis as theatre corrects the contradiction in acknowledging the fault. But more than this, through this genealogically informed reading of Hitchcock's texts, this thesis examines him in relation to apocalyptic moments as a position from which to assess his ideas about the geopolitics of the future. Hitchcock's ideas will be brought back to their earthly, human, beginnings and bring about a sense of responsibility for premillennial visions of the world making them part of the struggle of everyday life. Hitchcock, like the story of Icarus, flying above the farmers who thought he was a god, this thesis will melt those wax wings of the Rapture to bring premillennial dispensationalism back to the materiality and immanence of Earth; back into history and back into the immanent political struggle

\footnotetext{
${ }^{27}$ Foucault, 'A Preface to Transgression'; De Certeau, The Practice of Everyday Life.

${ }^{28}$ N. Gregson and G. Rose. 'Taking Butler Elsewhere: Performances, Spatialities \& Subjectivities', Environment and Planning D: Society and Space 24/4 (2000) pp.447.
} 
of identity and subjectivity. This thesis is not attempting to transcend Hitchcock's geopolitics; it is rather transversing the geopolitical representations laid plain by Hitchcock, but this does not preclude an escape, as the Rapture does require; transversing borders is an act of dissolving the act of bordering; it is still being of and on this earth. It is precisely this location of being on that is also at issue here; something that is critiqued through an anti-representational sentiment of 'us' and 'them' or 'good' and 'evil' dualisms.

A. G. Mojtabai described dispensational theory as a 'structuralist's dream...[that] reduces all of the Bible to a single basic plot'. ${ }^{29}$ Though premillennial dispensationalism may be a 'structuralist's dream' it is certainly not a 'basic plot'. The complex strategy of the 'plot', it is argued, is the Rapture: how the Rapture allows the prophecy expounder to delineate the world in preparation for Armageddon because he (and this gendering is appropriate) will be exempt from the horrors it anticipates. The Rapture is that moment before the Tribulation period where all true believing Christians will be beamed up into the sky to join Christ. It is transcendence of death, end or limit. This discourse is mobilized in support of truth; there is a great pull to the properties of the transcendent away from the immanent earthly, baneful, and immanently lost world. The Rapture, to use Pettman's vocabulary, is the 'floating signifier' that emphasizes an otherworldly order and harmony over the worldly disorder and disharmony. ${ }^{30}$ The Rapture, combined with Hitchcock equating his texts with the word of God, is the enablement of this

\footnotetext{
${ }^{29}$ A. G. Mojtabai, Blessed Assurance: At Home With the Bomb in Amarillo, Texas (Syracuse: Syracuse University Press, 1997) p.148.

${ }^{30}$ D. Pettman, After the Orgy: Towards a Politics of Exhaustion (Albany: State University of New York Press, 2002) p.2.
} 
epistemology as a strategy for readers to have faith that this geopolitical representation of the world is God-sent truth.

This attempt to bring the premillennial discourse back to the materiality of the human constructed world is done by unveiling the strategies that Hitchcock uses to convince the reader of his biblical and thus ordained geopolitical complex. In discussing the practice of everyday life, de Certeau defines the difference between strategies of power and tactics of resistance:

A strategy assumes a place that can be circumscribed as proper and thus serves as the basis for generating relations with an exterior distinct from it...strategies are actions which...elaborate theoretical places (systems and totalizing discourses) capable of articulating an ensemble of physical places in which forces are distributed...they thus privilege spatial relationships. At the very least they attempt to reduce temporal relations to spatial ones through the analytical attribution of a proper place to each particular element and through the combinatory organization of the movements specific to units of groups of units. ${ }^{31}$

Tactics, for de Certeau,. are those modes of resistance that privilege of time over space by transversing space:

[Tactics] cannot count on a 'proper' (a spatial institutional) localisation, nor thus on a borderline distinguishing the other as a visible totality. The place of a tactic belongs to the other. A tactic insinuates into the other's place. ${ }^{32}$

Strategies then define a territory of insides and outsides while tactics cross those spaces with 'other interests and desires that are neither determined nor captured by the systems in which they develop'. ${ }^{33}$ Strategies are the production of space through imbrications between power and knowledge. Hitchcock uses the knowledge of purity and purification and the power of exclusion with 'borders, which they institute for themselves, between

\footnotetext{
${ }^{31}$ De Certeau, The Practice of Everyday Life, p.XIX and p.38 italics mine.

${ }_{32}^{32}$ Ibid, p.XIX.

${ }^{33}$ Ibid, p.XVIII.
} 
themselves and those they oppress'. ${ }^{34}$ This thesis is primarily concerned with Hitchcock's strategies and not the tactics from which resistance is made possible.

De Certeau makes three suggestions about strategies summarized well by Gregory, 'that strategies mark the triumph of space over time (the production of a "proper place'-one's own/owned space); that strategies typically involve the mastery of places through sight (through a system of surveillance); and that strategies are revealed in the power "to transform the uncertainties of history into readable spaces". 35 This is not simply a reading strategy transported from de Certeau onto a very different subject matter. There are, however, consistent perfomative/theatrical modalities through which the world is interpreted and seen by Hitchcock. These strategies, which correspond to the chapters that follow are: (1) Hitchcock's 'Fatherly separation' through authorship that is confused with God's, ${ }^{36}$ which stems from his author-ity as a pastor with a $\mathrm{PhD}$ and also through what Foucault would call 'technologies of the self' or 'governmentality' which is a function of disciplining the self through performativity which he defined to be 'spiritually ruled and led on this earth in order to achieve eternal salvation'. ${ }^{37}$ This transcendent act to rise above the common, non-Christian person, gives way to a distancing perspective of (2) 'Seeing the Whole World' as separate from time to take a snap-shot of the world and draw the geopolitical battle lines of Armageddon without concern for being embroiled in the ensuing carnage of Armageddon; and (3) 'Knowing the Evil Other' through social and political exclusion, who for Hitchcock, are the 'Others'

\footnotetext{
${ }^{34}$ S. Pile, 'Introduction: Opposition, Political Identities and Spaces of Resistance', in S. Pile and M. Keith (eds.) Geographies of Resistance (London: Routledge, 1997) p16.

${ }^{35}$ D. Gregory, Geographical Imaginations (Oxford: Blackwell, 1994) p 169 and De Certeau, The Practice of Everyday Life, p36.

${ }^{36}$ On 'authorship' and 'authority' see also, M. Foucault, 'The Subject and Power', in H. Dreyfus and P. Rainbow (eds.), Michel Foucault: Beyond Structuralism and Hermeneutics (Brighton: Harvester, 1982) pp.208-209.

${ }^{37}$ Carrette, Michel Foucault: Religion and Culture, p.38.
} 
'out there' not truly believing in Christ's return; and also through a belief that the Bible reveals the reason and reasoning by which decisions are made by Others to invade Israel.

The strategies Hitchcock uses to distance himself from earth to be able to draw his apocalyptic geopolitics and judge the Other as a biblical actor is embodied in Figure 6 below and will be referred to throughout this thesis. This is in no way a complete taxonomy of the strategies Hitchcock uses but helps in devising a genealogy of how these pessimistic and fatalistic geopolitics are reasoned and made possible by writing the dramas on a world stage removed from the messiness of everyday life. In Foucault's more eloquent words, I will read Hitchcock 'without trying to seize hold of the inaudible when the word doesn't occur in the text' but will engage with the strategies outlined above. $^{38}$

The point of departure for this thesis is mooring premillennialism to a material existence and creation following Foucault's point that the soul is the prison of the body and not the Christian concept of the body imprisoning the soul. Foucault's 'heterotropic' or transgressive writing, as During argues, rejects traditionally 'stable' textual modes in order to 'clear an ideological space: a space for action, experimentation, chance, freedom, mobility'. ${ }^{39}$ To Edward Relph, Foucault's 'heterotropic' is 'pluralistic, chaotic, designed in detail yet lacking universal foundations or principles, continually changing, linked by centerless flows of information'. ${ }^{40}$ It then celebrates the materiality of the body, and relegates the soul to ideology, thus dismantling coherence and consistency that too often run in tandem with the humanist modes and narratives outlined in the above chapter.

\footnotetext{
${ }^{38}$ Quoted in Howarth, Discourse, p.52.

${ }^{39}$ Pettman, After the Orgy, p7 and 39.

${ }^{40}$ E. Relph, 'Post-modern Geographies', Canadian Geographer 35 (1991) p. 105.
} 


\section{Figure 6}

\section{THE PREMILLENNIAL SPATIAL SEPARATION OF RESPONSIBILITY}

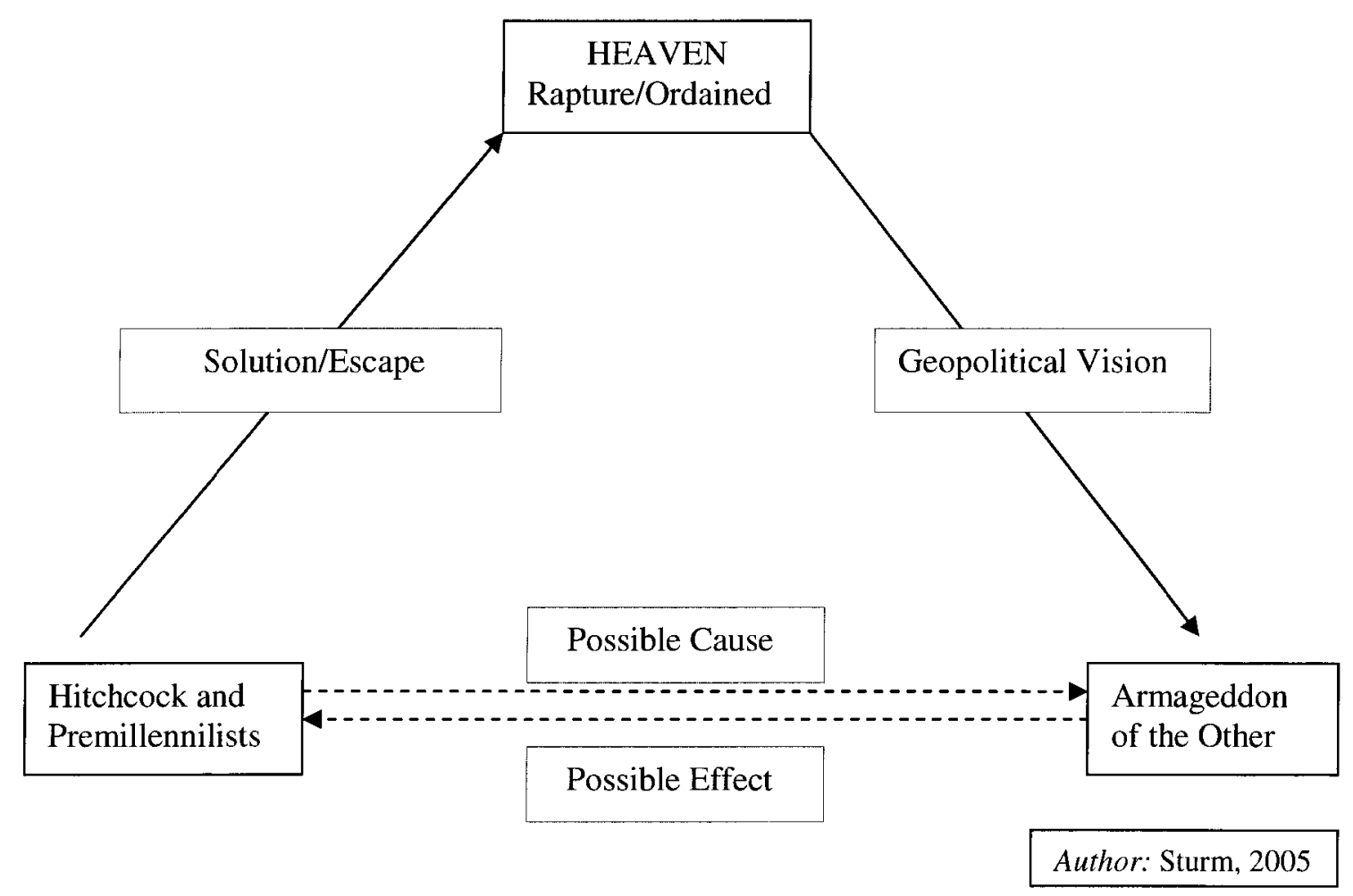

Therefore, as Pettman eloquently notes, 'fragmentation and rupture are privileged above unity and rapture' and he continues that in the 'space between such inconsistencies are forged the possibilities of the 'heterotropic' text, including the possibility of its own imminent collapse'. ${ }^{41}$ Pettman's paraphrasing of Foucault, here, is to suggest that the transgressive is not interested in recreating an ordered harmony that premillennialism has put forth, rather it is precisely the inconsistencies such a genealogical writing would lay bare that both collapses the transcendent and the meaning of the transgressive. It should be noted that Foucault's 'transgression' is seen here not as a 'tactic' for freeing the represented in de Certeau's rendering of the term, but rather as a method for pulling

${ }^{41}$ Pettman, After the Orgy, p.39-40. 
Hitchcock back to Earth exposing his strategies to deal with difference rather than escaping from it.

As Foucault notes with respect to Nietzsche and Sade, 'the death of God does not restore us to a limited and positivistic world, but to a world exposed by the experience of its limits'. ${ }^{42}$ The problem here is that through this immanence, or death of God, transgression gives way to tabula rasa or a 'limitlessness' for the epistemological construction of new earthly limits having buried the transcendent. Without the limit-and here it should be cautioned in much the same way a utopian discourse might construct itself-the transgressive loses its raison d'etre. It defines itself in relation to the metaphysical, Christian concepts of transcendence: it is of the infinity. Foucault explains that 'the limit and transgression depend on each other for whatever density of being they possess: a limit could not exist if it were absolutely uncrossable and, reciprocally, transgression would be pointless if it merely crossed a limit composed of illusions and shadows'. ${ }^{43}$ Therefore, exploring the transgressive requires a new mode-something this thesis would not be willing to expound on at length though in the conclusion of this thesis new modes of spaceless places will be briefly explored. The very 'nature' of the transgressive (and this terminology is used here with caution) is to seek out and move past limits and geopolitical borders through discursive passages that break such borders, dissolving the polygon that imprisons people as uniform evil by revealing the strategies used to construct such borders.

This is not, however, a subversive strategy or antagonistic, as Foucault rightly says: 'transgression does not seek to oppose one thing to another' because transgression is an

\footnotetext{
${ }^{42}$ Foucault, 'A Preface to Transgression', p.32-33.

${ }^{43}$ Ibid, p.34.
} 
affirmative gesture that should be clear of 'negative associations' ${ }^{44}$ It should be stressed then that this thesis in not an attack on Christianity in general, it does not oppose Christianity. It rather seeks to ground the particular forms of transcendent tropes that guide political, social, and cultural acts. Christianity has well within its grasp to embrace the 'face' of the Other, as Levinas put it, in recognition that the 'I' cannot exist without the 'Other' and therefore must find responsibility in accepting the Other. ${ }^{45}$ As McKenna put it:

The previous concerns of salvation and redemption are shifting into the background for the great majority of people, and what is driving religious feeling is a wish for contact-a relationship to the Other. The alien then falls into place in that role; the alien fulfills it. I believe that if religion survives into the long centuries of the future, this will be its compelling concern-an attempt to define a collective relationship with the Other that assuages our yearning and our feeling of being cast out or, as Heidegger says, "cast into matter, alone in the Universe". ${ }^{46}$

Perhaps McKenna's words are too utopian themselves but this passage is important in cutting through the transcendence of Christianity to reveal the earthly responsibilities Christianity can find below it. That is, Christianity can still be practiced as a transgressive religion; one that chooses to make this world better rather than seeking to escape from it.

The Bible in many places does, however, make clear this otherworldly character of the Christian existence. Note 1 John 2:15-17:

Love not the world, neither the things [that are] in the world.

If any man love the world, the love of the father is not in him.

For all that [is] in the world, the lust of the flesh, and the lust of the eyes, and the pride of life, is not of the Father, but is of the world.

And the world passeth away, and the lust thereof:

but he that doeth the will of God abideth for ever.

\footnotetext{
${ }^{44}$ Ibid, p.35.

${ }^{45}$ See E. Levinas, Ethics and Infinity: Conversations with Philippe, N. R. Cohen (trans.) (Pittsburgh: Duquesne University Press, 1985) p. 95 quoted in E. J. Popke, 'Poststructuralist Ethics: Subjectivity, Responsibility and the Space of Community', Progress in Human Geography 27/3 (2003) p.304.

${ }^{46}$ T. McKenna, The Archaic Revival (San Francisco: Harper, 1991) p.73
} 
This quote could be used as a source of transcendent and incontrovertible truth. The Bible is as seen in this thesis, however, 'something made', as is a particular reading of the Bible, and it can be interpreted in myriad of ways.

This analysis proceeds through what Watson describes as 'a carefully managed series of disclosures' of Hitchcock's strategies toward transcendence of the 'spectre of Armageddon'. 47

\footnotetext{
${ }^{47}$ Watson quoted in Gregory, Geographical Imaginations, p.147. See also J. Sharpe Condensing the Cold War: Reader's Digest and American Identity (Minneapolis: University of Minnesota Press, 2000), p.39.
} 


\section{Act 1:}

\section{The Father's Heavenly Separation}

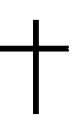

This chapter confronts the explicit theatrical analogies Hitchcock uses to construct his geopolitics. It explores how the world as 'stage' and politics as 'scenes' can have a dehumanizing effect. But more importantly, how such constructions of the world lift and separate the prophecy expounder and prophecy believer from accountability. It will attempt to bring premillennialism in general, and Hitchcock's work in particular, back to earth to deal with the complexities of daily life and to take responsibility rather than escape from it. It will attempt a Brechtianization of Hitchcock's theatre. Bertolt Brecht, who was well known for political theatre, influenced the theory of theatre by using techniques that reminded the viewer that the play is a representation of reality and not reality itself, this is what he called: Verfremdungseffekt (distancing effect). The idea, as a political message, was that the spectator should not emotionally identify with the play but rather should provoke a rational self-reflection and a critique of the actions set on stage. ${ }^{1}$ The second section embarks on an 'authorisation' of Hitchcock's privileged position as Holy or Godly author. It takes up Gregory's use of the term 'Authorisation' to raise questions on the subjectivity of Hitchcock's author-ity as a pastor, doctor and author.

\section{The Theatre of the Apocalypse}

\footnotetext{
${ }^{1}$ See F. Jameson, Brecht and Method (New York: Verso, 2000).
} 
The theatre metaphor is a commonly used moniker for the End Times by many prophecy expounders. ${ }^{2}$ Though other metaphors have been employed, namely nature, theatre dominates the texts. It is the metaphoric lode. Considering the visual centrality of the Rapture, the geographical signs, and the vivid portrayal of Armageddon, the metaphor provides a vessel from which to make 'real' the story that seems so 'unreal'. Prophecy seers are admittedly like film directors and playwrights, drafting and redrafting their tales of a reality they see coming to fruition; a reality certainly informed by a specific reading of world politics.

Viewing the Apocalypse as theatre is an escape strategy. Boyer observes that, 'this metaphor also suggested a performance one can savour precisely because one knows the outcome' and continues, 'watching the events unfold is similar to viewing a play after having read a synopsis of the drama. We recognized the main characters and we are able to forecast many of the major twists in the plot. We are certain, in advance, of exactly how the story will end'. 3 Theatre becomes a reassuring analogy to appease those struggling with the realities of war because it reduces global developments to mere 'scenes' and 'actors' in a drama whose script one holds in their hands. 'Apocalyptic was born of crisis', writes Freedman, and as Collins continues this thought, 'it was...the consolation of the persecuted'.

The theatre metaphor and stage performance of the Apocalypse has existed for at least one thousand years. As Bernard McGinn makes very clear, Apocalyptic figured prominently in the discourses of the Middle Ages, often performed in plays like the

\footnotetext{
${ }^{2}$ P. Boyer When Time Shall Be No More: Prophecy Belief in Modern American Culture (Cambridge, MA: Harvard University Press, 1992) p.316.

3 Ibid, p. 317 .

${ }^{4}$ Freedman quoted in J. J. Collins, The Apocalyptic Imagination: An Introduction to Jewish Apocalyptic Literature (Grand Rapids, MI: Eerdmans, 1998) p.18 and 29.
} 
famous Oberammergau Passion Play and Hildegard of Bingen of the twelfth century, whose religious compositions apparently had a wide and lasting influence. ${ }^{5}$ Much of her writings still exist, including pictures illustrating the texts of 'Medieval maps that sometimes portrayed Gog and Magog as demons imprisoned behind a wall in northeastern Europe'. ${ }^{6}$ The Play of Antichrist, a German religious drama dating around 1160 , enjoyed vast popularity, showing the Antichrist, just as he is depicted today, as the representation of destruction though eventually defeated with righteousness prevailing. ${ }^{7}$ In Germany at this time, Apocalyptic sentiment was exacerbated by the territorial struggle between the papacy and German rulers which Cohn uses to show the very political aspect of apocalyptic thought. ${ }^{8}$ Even Cyrus Scofield, who was one of the major evangelists of premillennial dispensationalism in the early twentieth century, used theatrical metaphors to describe the apocalypse when he wrote of 'the immense drama of human history' to come. ${ }^{9}$

Rather than the theatrical metaphor taken by many modern prophecy writers, St. Augustine, however, chose to see God as a composer and conductor, an invisible guidance that could only be heard if one was willing to listen. The visual centrality that we see in modern prophecy work was not part of his works precisely because Augustine did not see an earthy apocalypse; rather he saw a metaphorical separation of the cities of Jerusalem and Babylon, respectively, good and evil, to the point when the latter no longer

\footnotetext{
${ }^{5}$ B. McGinn, Apocalyptic Spirituality: Treatises and Letters of Lacantius, Adso of Montier-en-Der, Joachim of Fiore, the Franciscan Spirituals, Savonarola (London: Paulist Press, 1979) p.21. See also Boyer, When Time Shall Be No More, p.50-51.

${ }^{6}$ Boyer, When Time Shall Be No More, p.51.

${ }^{7}$ C. Hill, Antichrist in Seventeenth-Century England (London: Oxford University Press, 1971) p. 6.

${ }^{8}$ N. Cohn, The Pursuit of the Millennium: Revolutionary Millenarians and Mystical Antichrists of the Middle Ages (London: Temple Smith 1970 [Originally published in 1957]) p.211-14. At this time, the German ruler, Fredrick II, was labelled as the 'Emperor of the Last Days' who would usher in the millennium.

${ }^{9}$ Boyer, When Time Shall Be No More, p316.
} 
existed. Augustine writes, 'He is ordering all events according to His providence, until the beauty of the completed course of time, whose parts are the dispensations suitable to each different period, shall have played itself out, like the great melody of some ineffable composer'. ${ }^{10}$ St. Augustine chose to describe one's relationship with God and God's relationship to the earth as an auditory sense, though still a 'remote' sense which tells the subject about distant parts of their environment; it is not a geopolitical sense in that it does not distinguish global territory; albeit it does offer an affirmation between the 'self' and 'other'. Hearing defines difference on a small and individual scale and to Augustine, listening was a way to personally feel God. The visual on the other hand, shows people and dictates for people the work of God. The visual sense, then, is utilized by prophecy expounders to relate to the 'realities' of an immanent global division in geographic terms.

Premillennialists have used visual and theatrical aids in Evangelism and as teaching aids since the technologies were available. With the advent of the publishing industry, TV, cinema, books, and other print media, the world was better visualized. During the beginnings of the Cold War, photographs of mushroom clouds, films, TV and videocassettes, were used by prophecy popularizes to make the coming apocalypse visible. " Beyond the obvious theatrics of the TV ministries of Jerry Falwell, Pat Robertson, and Jimmy Swaggart, all of whom emphasized the Soviet Union's end-time role, the Post World War II era saw the theatre metaphor revived with Russia's domination of East Germany and its influence in Asia. As Coder triumphantly animated in 1963, 'surely [this] mean[s] that the stage is being set for the earth-shaking events of

\footnotetext{
${ }^{10}$ This is an observation made by P. Brown, Augustine of Hippo: A Biography (Berkeley: University of California Press, 1969) p.315.

${ }^{11}$ Boyer, When Time Shall Be No More, p. 124.
} 
the last days, ${ }^{12}$ Apocalyptic theatre was increasingly bound up in the United States military and Hollywood vocabulary, particularly with the imagination of Hal Lindsey who translated 'fire and brimstone' to mean tactical nuclear weapons and the locusts of Revelation to represent warheads fired from space (See Figure 7). ${ }^{13}$ As Michael Barkun observed of Lindsey:

As the exclamation points march forward, it becomes clear that Lindsey finds these prospects enormously attractive. His prose pants on with scarcely a word of sympathy for the hundreds of millions killed or maimed. For him, the tribulation is grand, cosmic theatre, the ultimate Hollywood spectacle. ${ }^{14}$

Lindsey's work will be explored further in the chapters that follow, though it should be said here that his focus on the geographical 'signs' of the Apocalypse combined with his popularity in and outside of religious circles informed Apocalyptic sentiments in Hollywood and in the work of prophecy expounders like Hitchcock. Smith, a filmmaker and prophecy writer, for example, used Lindsey's texts on many occasions. He wrote: 'It's as if we were backstage at a play feeling the drama and excitement just before the curtain rises for the final act. The director is positioning all the players and seeing that the props are all in order before he signals for the curtain to rise'. ${ }^{15}$

\footnotetext{
${ }^{12}$ Ibid, p.159.

${ }^{13}$ Note the 'Russian Amphibious Assault' of Chart One. H. Lindsey, The Late Great Planet Earth (Grand Rapids, MI: Zondervan Books 1970) p139-144.

${ }^{14}$ M. Barkun, 'The Language of Apocalypse: Premillennialists and Nuclear War', in M. W. Fishwick and R.E. Browne, (eds.), The God Pumpers: Religion in the Electronic Age (Bowling Green OH: Bowling Green State University Press, 1987) p. 167.

${ }^{15}$ Boyer, When Time Shall Be No More, p317.
} 
Figure 7
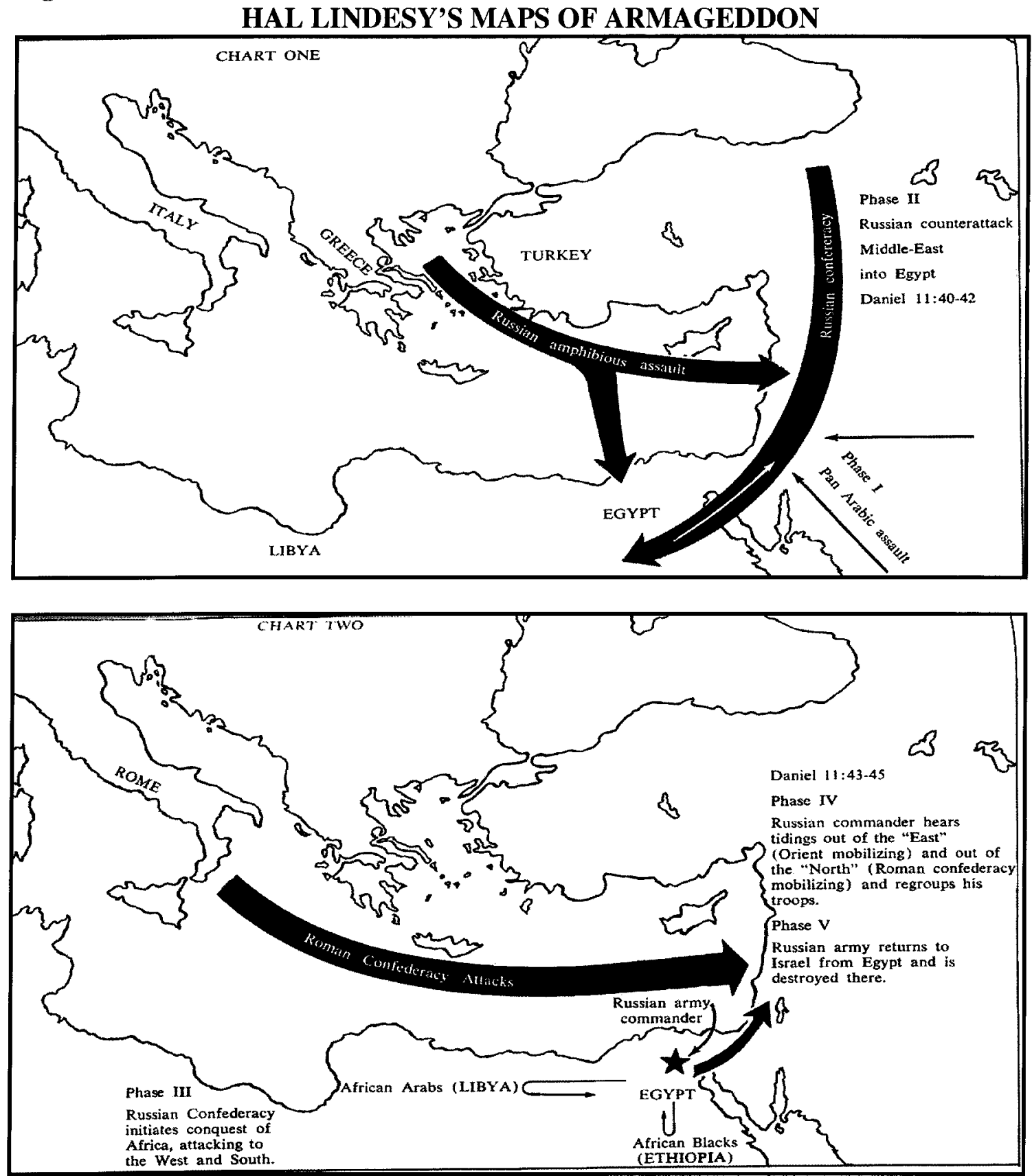

Sources: Hal Lindsey, Late Great Planet Earth (1970).

W. Warren Wager in his 1982 book Terminal Visions compiled a list of hundreds of secular and religious novels and plays on the Apocalypse that poured out of the 1970s. As Wagner writes, these texts seemed to capitalize on the rise of Evangelicals at this time; a time that saw the decline of mainstream churches and in contrast a steep increase 
in so called 'born-again' or Evangelical Christians. ${ }^{16}$ Tim LaHaye and Jerry Jenkins' best selling book series, Left Behind, is a prophetically informed fiction, though intended as a form of didacticism, of how the authors envision the world after the Rapture. The End Times are melodramatically depicted in action sequences comparable to Independence Day (1996), though the confused pseudo-Christians left behind after the Rapture do not fight aliens, they fight the UN 'World Potentate' (Antichrist) who 'looks not unlike a young Robert Redford' and is voted 'sexiest man alive' by People Magazine. ${ }^{17}$ History is written in these books to transform the typical suburban American into apocalyptic, evangelical superheroes. The difference between the fictitious or secular versions of the apocalypse is that in the conclusion the 'good' usually prevail not through a vehicle of escape but rather through a method of transgression. However there are also Hollywood versions of the escapist premillennial like the 1991 film The Rapture, staring Mimi Rogers, whose life is filled with sexually promiscuous activity, but finds herself 'saved' just before the Rapture occurs.

\section{Theatre as Strategy: The Only Way Out is Up}

Apocalypse means 'unveiling that which is hidden', in other words (and to Hitchcock), making visible the world's unseen geography. Donna Haraway explains that vision is always culturally performed and contingent on the space in which it is represented and obscured. ${ }^{18}$ 'Unveiled' spaces of the Other are therefore spaces of invisibility and

\footnotetext{
${ }^{16}$ W. W. Wager, Terminal Visions: The Literature of Last Things (Bloomington: Indiana University Press, 1982).

${ }^{17}$ T. LaHaye and J. B. Jenkins, Left Behind (Wheaton, IL: Tyndale, 1995). G. Lyons, 'The Apocalypse will be Televised: Armageddon in an Age of Entertainment', Harper's Magazine, Nov. 2004, p.88.

${ }^{18}$ D. J. Haraway, Simians, Cyborgs and Women: The Reinvention of Nature (London: Routledge, 1992) pp.188-196.
} 
intractability. Vision is an author-itative and privileged form of knowledge-an acknowledgment that is not foreign to the geographer with her/his visual renderings of Earth. Vision pervades Western thought, in general, and geopolitics, in particular. This ocularcentrism privileges space over time through a snapshot of how the world appears at a single point-in-time. Biblical history and geopolitics, then, merge with a teleological drive toward absolutes with the result of speciously inevitable, but depoliticized, geopolitics. Political, economic, and social inter-relations are seen as Biblical processes. Using Hitchcock's formulation of the Rapture as theatre, this section devises a theory of theatricality as a practice of distancing the playwright and reader from earthly responsibility - a separation from the world to the gallery, from the 'real' to the imaginary. This is not to say that this rehearsal and scripting of Hitchcock's texts is not theatrical; any manifestation of the social can be written this way. Describing the discourse makes a representation of Hitchcock on this stage: this paper. ${ }^{19}$ The difference is that it is recognized that this thesis is a form of theatre and is thereby caught up in power relations and subjective representations.

The Western propensity to privilege vision as the 'most noble of the senses' has waxed and waned from the Hellenistic period but has gained prominence since the Renaissance-era. ${ }^{20}$ However, the Protestant Reformation's questioning of authority gave way to perspectivism in art and the mapping of perceived facts about the world. The antiiconography of the Protestant Reformation and the Counter-Reformation's use of images to combat the Protestant revolution are worth noting here. Evangelicals are Protestants yet the proliferation of televangelism (yet in this case Hitchcock's use of maps and

\footnotetext{
${ }^{19}$ On the theatre of the publishing industry and higher education, see E. B. Gorham, The Theatre of Politics: Hannah Arendt, Political Science and Higher Education (Lanham, MD: Lexington Books, 2000).

${ }^{20}$ M. Jay, Downcast Eyes (Berkeley: University of California Press 1993) pp.21-82.
} 
theatrical metaphors) seem to run contrary to Protestantism's early resistance to Holy effigies and other visual representations. This is a major chronological and cultural leap from the Protestant Reformation to modern Evangelicals. However, the point here is that theatricality and iconography was never relegated completely from religious ceremony, practice or representation-where, for example, the mise-en-scène of America for the Puritans was that of Promised Land. The Puritans, for example, were known to destroy religious images and were incredulous of the theatrical stage. ${ }^{21}$ But as Phillips recounts, when resistance to Puritan beliefs arose or when the world appeared incomprehensible, visual images were used to recompose religious order. ${ }^{22}$ Furthermore, Kubiak has argued that the Puritan diaries were theatrical texts of the mind: from 'watching' and 'being watched' in the Puritan writings of John Winthrop and Michael Wigglesworth to the 'self-surveillance' of Thomas Shepard. ${ }^{23}$ They, in Kubiak's words, invoked 'a theatre that was not merely representational... [it was rather] a theatre that was somehow more real than the world within which it appeared' ${ }^{24}$ In a more apocalyptic vein, the American Puritan Cotton Mather (1663-1728) also found signs of the Second Coming in world events and in his sermon 'Things To Be Look'd For' (1691) that predicted the Ottoman Empire would destroy the world in $1697 .^{25}$ Similarly, the Counter-Reformation fought resistance and disorder with images. The Jesuits in the seventeenth century, as Ó Tuathail

\footnotetext{
${ }^{21}$ Ibid p.43, Jay makes this point as an aside in footnote 74.

${ }^{22}$ J. Phillips, The Reformation of Images: Destruction of Art in England, 1535-1660 (Berkeley: University of California Press 1973) p.166, quoted in Jay, Downcast Eyes, p.43.

${ }^{23}$ A. Kubiak, Agitated States: Performance in the American Theater of Cruelty (Ann Arbor: The University of Michigan Press, 2002) pp.29-52. Shepard was known to use the theatre to describe hypocracy, for example, 'a stage player, that acts the part of king, wants the glory of king'. That is, Shepard critiqued the use of theatre to act as 'heavenly' as Hitchcock does in his books. .J. H. Richards, Theatre Enough: American Culture and the Metaphor of the World Stage, 1607-1789 (Durham: Duke University Press, 1991) p.111.

${ }^{24}$ Ibid, p.30.

${ }^{25}$ Boyer, When Tomorrow Shall Be No More, p.69.
} 
notes, used 'magic lantern slides' in geography and history lectures to depict 'apocalyptic images of the flames of Hell, burning cities, and Armageddon' as theatric tools to evangelize fear in an attempt to re-seize order over people confused in the Reformation. ${ }^{26}$

The story of American Apocalyptic, as many have pointed out, began with the Puritans. ${ }^{27}$ The theatre metaphor in America also has had a long standing tradition beyond simply prophecy. John Adams, in a 1765 diary entry, described America's manifest destiny and the European settlement of America as 'the opening of a grand scene and design in Providence for the illumination of the ignorant and the emancipation of the slavish part of mankind all over the earth'. ${ }^{28}$ And Abraham Lincoln's Second Inaugural Address, which made clear that God's hand was spread over world history, said 'Mine eyes have seen the glory of the coming of the Lord...' ${ }^{29}$ Amid these times, Hatch writes that the democratization of politics and religion in America embedded the idea that 'Americans of all ranks sensed that events of truly apocalyptic significance were unfolding before their eyes'. ${ }^{30}$

Like Cold War geopolitics, Protestantism, Catholicism, and more specifically premillennialism, have all operationalized and legitimized various visual tropes, strategies, and fictions in times of new and never-ending distress to (re)construct a particular world with the result of fulfilling its own prophecies. ${ }^{31}$ The endless repetition of the Rapture as theatre becomes the script and score. And the effectiveness of the

\footnotetext{
${ }^{26}$ Ó Tuathail, Critical Geopolitics, p.276. Ó Tuathail makes this point as an aside in endnote 38.

${ }^{27}$ See, P. Miller, The New England Mind: From Colony to Province (Cambridge: Harvard University Press, 1953) and S. Bercovitch, The American Jeremiad (Madison: University of Wisconsin Press 1978).

${ }^{28}$ For Adams' many uses of theatre, see J. H. Richards, Theatre Enough: American Culture and the Metaphor of the World Stage, 1607-1789 (Durham: Duke University Press, 1991) pp.230-246.

${ }^{29}$ Boyer, When Tomorrow Shall Be No More, p.229.

${ }^{30}$ N.O. Hatch, The Democratization of American Religion (New Haven: Yale University Press, 1989) p.185.

${ }_{31}$ J. Agnew and S. Corbridge, Mastering Space: Hegemony, Territory and International Political Economy (London: Routledge 1995) p.76.
} 
theatre is what makes it 'real' to the role-playing premillennialist. In the construction of this world, premillennial geopolitics reduces complexity to simplified regions, identities, and perspectives. For instance, Hitchcock claims that 'God has already written the script for the end times and is preparing the world stage for His drama of the ages' and that, 'Before the curtain lifts, the church will rise in the air to meet the Lord at the Rapture'. ${ }^{32}$ Hitchcock appears, here, to have the power to transcend everyday life across the globe to find the real problems with the world. The (re)projection of this 'theatre' to the viewer often displays what the viewer wants to see or provides new information to support presuppositions about the world (after all, the reader/viewer bought the book/ticket). What is not acknowledged is that theatre is a representation of $a$ reality and a part of the visual epistemology. By using the theatre metaphor, Hitchcock tacitly understands this singular representation of $a$ reality but side-steps the possibility of self-reflexivity-an unreflexive blindness - by exclaiming the ineffable truth of his/His metaphor through the Rapture and his ordained reading of the Bible. Thus, although the Brechtian space of distancing is invoked in the Rapture-theatre, the spectacle is thought to be 'reality' and not the play that it is.

Theatre is a panoramic vision of an idea refocused by the playwright on a single graspable point. It allows the viewer to see the whole but is also a practice of making the world visible in specific ways. In short, theatricality is a technology of vision and thus is the metaphorical equivalent of what Donna Haraway warns as the 'god trick of seeing everything from nowhere'. The panoramic gaze is achieved by leaving the body through the proxy of the Bible; it is an act of putting myth into ordinary practice. ${ }^{33}$ Through the

\footnotetext{
${ }^{32}$ Hitchcock, What On Earth Is Going On, p.44.

${ }^{33}$ Haraway, Simians, Cyborgs and Women, p.189.
} 
Rapture, premillennialists have been privileged to be invited to join God in auditoriumHeaven to watch the cataclysms on stage-Earth. They are, in a sense, demi-gods, occupying a venerable altitude above the complexities of the everyday, visually comprehending the geopolitics of the End Time play. The metanarrative of the Rapture as a looking down upon Earth, understanding, and seeing all from Heaven, is a theatric concept and thus a form of generalizing power: being omniscient of all, past/present/future. The boon of the Rapture is anachronistically transposed to the soothsayers of Earth, giving earth-bound premillennialists the elevated power over nonevangelicals to be able to see in a wide-eyed fashion the whole-wide-world, the end of the world, and who 'they' are.

Theatre is the peerless example of a visual practice that allows one to be able to defeat time by way of simultaneity and fixed essences. In the elevated seats, lights are dimmed to obfuscate and blur one's peripheral vision, thereby restricting vision to a single point of view, or 'tunnel vision', toward the stage. The stage then becomes the whole world. Though a single world is projected to the observer, the externality of sight allows the observer to distance themselves from the object or scene and in the process avoids complicity and responsibility for their actions and the counter-actions of the actors. The premillennialist, through the Rapture, is solely an observer and not a worldly actor. The Rapture is a spatial removal of responsibility where the causality, or in this case the self-fulfilling prophecy, 'between the object and subject [where] the link is suppressed or forgotten', is lost. ${ }^{34}$ The direct relationship between the viewer and viewed made clear in the gospel: 'they have eyes that they might not see', is forgotten by

\footnotetext{
${ }^{34}$ Jay, Downcast Eyes, p.25.
} 
Hitchcock. ${ }^{35}$ The viewer is looking at one point-the stage-but is in fact looked at by the actors which are ignored through a linear gaze. In other words, there is a dynamic between the stage and the audience that makes the theatre and performance possible. The premillennialist's visually constructed xenophobia (a fear of foreigners, whether of another country or religion) relates to an ophtalmophobia (that of a fear of eyes or fear of being stared at) of the Other under the misrepresentation of a foreign gaze by the viewed. As such, the single standpoint of the dominator refuses vision from the standpoint of the subjugated and acts as what Haraway calls a 'politics of closure'-a closure that does not problematize the premillennialist's role in constructing, shaping and influencing the theatre. $^{36}$

Brought on by the ingenuity to give prophecy a contemporary spin, theatricality as a political technology has deep implications to mount a self-fulfilling prophetic theatre production. That American geopolitical representations of the Middle East and the recent wars therein are preordained events set out in the Bible is deeply political, all of which, for Hitchcock, are epiphenomena that Christ will soon return. It is what Ó Tuathail has called a '(con)fusion of geopolitics and religious discourse' ${ }^{37}$ With the Rapture ever nearing, why should premillennialists concern themselves with war and strife when all worthy Christians will be saved upon Christ's return? Knowledge of the future is a 'scapegoat' ${ }^{38}$ or way to escape having any responsibility for the present Earth and is a

\footnotetext{
${ }^{35}$ Ezekiel 12:2 quoted in J. Lacan, The Four Fundamental Concepts of Psycho-Analysis, J. A. Miller (eds.), A. Sheridan (trans.) (London: Penguin 1979) p.109.

${ }^{36}$ Haraway, Simians, Cyborgs and Women, p.96.

${ }^{37}$ G. Ó Tuathail, 'Spiritual Geopolitics: Fr. Edmond Walsh and Jesuit Anti-Communism', in K. Dodds and D. Atkinson (eds.), Geopolitical Traditions: A Century of Geopolitical Thought (London: Routledge 2000) p.188.

${ }^{38}$ R. Girard, 'Generative Scapegoating', in R. H. Kelly (ed.), Violent Origins (Stanford: Stanford University, 1987) pp.95-103. See also B. R. Bater, 'Apocalyptic Religion in Christian Fundamentalism', in M. Wallace and T. H. Smith (eds.), Curing Violence (Sonoma, CA: Polebridge Press) pp.287-304.
} 
practice that individuals inflict upon themselves when this history and geography is made to seem natural and normal. Quite simply, and as most professional geographers and cartographers would agree, it is too simplistic to assume a totalizing theatric play or orthogonal map of Muslims, Russians, or Europeans because of a multiplicity of social, political and economic dimensions therein.

\section{Hitchcock's Author-itative Power and Authorisation as Transgression}

The power of apocalyptic is implicit in how it is constructed and where it is found: its source is God. And this is the implicit message Hitchcock makes known by citing the Bible: it's true because his work is written as the inerrant dictation from God. The Rapture, which makes earthly Christians heavenly projections, is dealt with through a reconstruction of Hitchcock's application of the theatre metaphor. For the premillennialist it becomes security for true believers, and not for those who 'pretend' to believe-the Rapture will distinguish them. Essentially, only those with authority and privilege to have the knowledge of God's great plan, and also truly believe in it, will have security. As James Duncan also strived to do, this section strives to deny the Holy authority of the author: in this case, Hitchcock. ${ }^{39}$

'Author-itative power' is a form of power realized through text. The power of the text takes advantage of the idea that if published, it must hold some truth. Hitchcock goes further to claim that his texts are representative of God's work: 'current events can provide discernible signs of the end times'. ${ }^{40}$ 'Authorization', defined here using Gregory's words 'is an attempt to make that [author-itative] dimension more explicit by

\footnotetext{
${ }^{39}$ T. Barnes and J. Duncan, (eds.) 'Introduction: Writing Worlds', in Writing Worlds: Discourse, Text and Metaphor in the Representation of Landscape (London: Routledge, 1992) p.6.

${ }^{40}$ M. Hitchcock, What on Earth is Going On (Sisters, OR: Multnomah, 2002) p.46.
} 
raising a series of questions about the inscription of subjectivity and the operation of power-knowledge: about the privilege of position and about authorship and authority, representation and rights'. ${ }^{41}$

In a telephone conversation with Hitchcock, he mentioned he had a new book that is set to be released August $1^{\text {st }}, 2006$ entitled, Iran in the Coming Crisis: Radical Islam, Oil and Nuclear Threat, that relates Iran's nuclear program and the recent tensions between Iran and the United States to prophecy. He went on to suggest that, indeed when he published his first book, The Silver Kingdom: Iran in History and Prophecy that he was, quote, 'ahead of his time' in terms of getting the prophecy 'right'. ${ }^{42}$ Implicitly he was revealing that he could be 'wrong' about prophecy, which revealed the political contingencies his work is based on (that of the current tensions between Iran and the United States). But more than this he was revealing that his authority was justified as a prophet.

Looking at the world as a picture separated from the 'self' circumnavigates the problematic of presuppositions of thought. Hitchcock, as an all-knowing observer is set apart from the terrestrial space he maps. This perspective is not endemic to Christianity; rather it is a European phenomenon associated with the Renaissance which privileged vision as the dominant sense. ${ }^{43}$ Foucault traces this moment to the outset of Western society's focus on vision as the dominant sense in The Order of Things with the early eighteenth century, that 'words' were then seen divided from 'things' and it was made that main purpose of natural science to bring the words or descriptions as close as

\footnotetext{
${ }^{41}$ D. Gregory, Geographical Imaginations, p. 105.

${ }^{42}$ Telephone conversation with Mark Hitchcock on March 22, 2006.

${ }^{43}$ Agnew, Geopolitics, pp.13-17.
} 
possible to the things. ${ }^{44}$ The historical beginnings of vision's domination over the senses, however, is not at issue here. Suffice to say, there can be no absolute knowledge and no supreme intelligence that makes timeless pictures of the world. And there is no single 'view from nowhere' or even 'news from nowhere. ${ }^{45}$

Language, to Hitchcock, is an unproblematic relayer of information separate from the realm of thoughts and concepts of things. And partially because of this, Hitchcock's biblical vision should not come without transgression precisely because his imagined geopolitics is a representation from a speciously unquestionable author-ity. To present the premillennial map as natural, as the Bible is seen as 'inerrant', is to forget the personages and subjectivities that interpreted it. Hitchcock blurs this problem through rhetorical technologies of author-itative power and a spatial removal of responsibility between the border of Heaven and Earth. He hopes that, 'God [will] use... [his] book in your life to help you trust His Word more fully, see His sovereign control more clearly, and live for Him more faithfully'. ${ }^{46}$ This demonstrates that Hitchcock does not force his geopolitical interpretations on his readers through authorship; rather, God does. He transforms uncertainty and ambiguity into certainty beyond critique, presenting a spectacle of tangible and timeless geographical 'truths'. Because time is at the mercy of space in this

\footnotetext{
${ }^{44}$ From D. Gregory, Geographical Imaginations, p.21.

${ }^{45}$ This is a reference to William Morris' novella of the same name. 'Nowhere', for Morris, is a play on Thomas More's novella Utopia - 'utopia' in Latin translates to 'nowhere'. See W. Morris, News from Nowhere and Other Stories Clive Wilmer (ed.) (New York: Penguin, 1998) pp.41-231, and T. More, Utopia (Mineola, N.Y.: Dover, 1997). More's Utopians, had many religions and no one religion was in hierarchical standing and 'no man ought to be punished for his religion' (p.73). He does however tie constancies to all of the religions of Utopia, which could be considered Christian sects as they all hold to Christian principles as what More notes as the most 'natural of ways'. All acknowledge 'God to be the author and governor of the world' (p.80-81). Despite the Utopians acceptance of religion, More implicitly and explicitly makes reference to the wrong religion, that of Catholicism. In a sly chastation of Catholicism and Catholic Popes, he writes, 'the most indecent thing possible [to Utopians is] if men who are particularly distinguished by the title of the faithful, should not religiously keep the faith of their treaties' (p. 63).

${ }^{46}$ M. Hitchcock, The Second Coming of Babylon (Sisters, Ore.: Multnomah Publishers 2003) p.12.
} 
dominant visual centrality, he is taking a snapshot of the world using his perceptions of the world. ${ }^{47}$

The observer does not replace the Creator in the premillennial soothsaying. Although God has omnipotence and omnipresence over history and geography, the observer is given the faculty to read the geography of God's work. As Hitchcock puts it, 'we see the signs all around us' and they are impossible to miss for the "“signposts" turn into neon banners! ${ }^{48}$ Hitchcock uses his expertise as a prophecy scholar and his authority as a pastor to make himself appear disinterested. From this position he reads the Bible unproblematically conflated with selective sources of global politics and biblical quotes. Hitchcock as a strategist, and from his panoptic Church steeple, sees himself as a disembodied, disembedded, and unsituated vessel of God. This forecloses the critical faculty of his readers: his privileged knowledge grants a blessing of perspective.

A mix of the strategy to write an ordained text combined with the creation of a geopolitics 'out there' depoliticizes prophecy to the believer despite it being entrenched in politics and thus resisting self-reflection and self-critique. It distances itself from political inquiry through the inerrancy of the Bible. A performative articulation of prophecy is a form of political security of the theory of premillennialism. The economy of signs provides a particular order to the world and is enabled through eschatology as a way to see the world. This economy of signs hides the politics of its own institution and principles by exporting the signs outside its theology and outside its territorial borders of allegiance. These signs are presented as biblical, apolitical and disinterested interpretations: they are the world. The creation of discursive enemy is used to securitize

\footnotetext{
${ }^{47}$ See Agnew, Geopolitics, pp.32-48.

${ }^{48}$ Hitchcock, The Second Coming of Babylon, pp. 32 and 23.
} 
prophecy's borders by placing the focus 'out there'. It is a discursive crystallization of signs, like that of Hitchcock's 'Jig-saw puzzle' pieces. ${ }^{49}$ It is this crystallization of signs that depoliticizes the self/other relationship as natural and thus 'real', particularly when the author is mirrored with the authority of God. By applying disinterested eschatological frameworks as a method for finding facts of the world 'out there' Hitchcock can legitimate the truths of the world 'in here'.

Since premillennialism's beginnings, many so called 'unqualified' seers without theological training have been premillennial augurs, writers, and cartographers. ${ }^{50}$ However, according to Hitchcock, not just anyone can 'look at world events through "prophetic eyes",;" Hitchcock makes it clear that he, and not his congregation, has exclusive power to interpret the geography of the Bible. This is combined with claims to the obviousness of his geopolitics: 'Think of it! The stage is being set right before our eyes. God's script is being followed to the tee. The Jig-saw puzzle picture on the top of the box is taking form'. ${ }^{52}$ All of the 'the end-time stage furniture...[is being set in] place'. ${ }^{53}$ And therefore, 'the current rise of Iran to a place of power in the Muslim world should not surprise us! Rather, it is just one more piece of the prophetic puzzle that is falling into place before our eyes'. ${ }^{54}$ Hitchcock becomes the homiletic Father of space. And as the Father he is the 'I/eye that observes...disciplines the ambiguity, contingency,

\footnotetext{
${ }^{49}$ Hitchcock, The Coming Islamic Invasion of Israel (Sisters, Ore.: Multnomah Publishers 2002) p. 65.

${ }^{50}$ Boyer, When Tomorrow Shall Be No More, p.99.

${ }^{51}$ Hitchcock, The Second Coming of Babylon, p. 10.

${ }^{52}$ Hitchcock, The Coming Islamic Invasion of Israel, p.94.

${ }^{53}$ Ibid, p.65.

${ }^{54}$ M. Hitchcock, The Silver Kingdom: Iran is History and Prophecy (Oklahoma City: Hearthstone

Publishing 1993) p.6.
} 
and (barbarian) chaos of international affairs and the world ${ }^{55}$ And in so doing also reduces the world into simple 'formulas of causation'. ${ }^{56}$

Like Hitchcock's Apocalyptic geopolitics, Kennan's famous 'Mr. X' article (and the domino theory that stemmed from it) and Mackinder's 'Geographical Pivot of History', both make prognostications of the strategic ends to history through a 'gaze' over the power of geography. ${ }^{57}$ The power to write and decipher the future of the world is a simple equation of causation: if Asian countries become communist, or if Russia controls Eastern Europe, then they will control the world's economy. With such simplistic equations, debate is lost to a single teleology. Moreover, the knowledge that this is a 'correct' result of socio-geographical transformation is also to make it the 'truth' and, at times, a self-fulfilling prophecy. Similarly, premillennial geopoliticians see geography as a foreordained projection of history. Reading biblically inspired geography is therefore reading the future. Knowledge, whether religious, political or both combined, is power; it has the power to move the world and make sense of it. Whether it's a Mercator projection or a Biblical map, how one writes and interprets that map-text is based on one's author-itative power, interpretive knowledge, presuppositions, and other subjectivities.

There is a self-disciplining spatial separation here where peregrination from one boundary passes into another space transforming the 'self' in the process. The Rapture is a type of boundary that marks difference: an ephemeral 'purgatory' moving humans from a baneful earthly existence into a Divine cloister. Premillennialists believe they are not

\footnotetext{
${ }^{55}$ Ó Tuathail, Critical Geopolitics, p.34.

${ }^{56}$ Ibid.

${ }^{57}$ G. F. Kennan, 'The Sources of Soviet Conduct', Foreign Affairs 25/4 (July 1947) pp.566-82; H. Mackinder, 'The Geographical Pivot of History', The Geographical Journal 170/4 (2004 [Originally published in 1904]) pp.298-321.
} 
citizens of this world; instead they are citizens of Heaven and their bodies are ephemeral vessels. The Rapture is a static strategy that is outside history and is contingent only on the ability of the augur to read geography. The Rapture allows one to live forever, and in a sense, be in control of their believing lives through the knowledge of history's end and the knowledge of theo-cartographic tools that have the power to pry into the Bible and read the (political) geography. Michel De Certeau writes in this regard, that 'To be able to see (far into the distance) is also to be able to predict, to run ahead of time by reading space'. ${ }^{58}$ Maps and geopolitical representations on them allow the Biblical cartographer to get a handle on history's timeline. Geography is a 'sign' and handle that makes history and premillennial belief tangible and secure.

The Rapture, combined with the idea that premillennialists are foremost citizens of Heaven, removes them from Earth's gravity to float freely above the complexities of everyday life and responsibilities for the Other. With the Rapture, premillennialists become pure observers of Earth's great spectacle. ${ }^{59}$ From their premillennial seats they can see with 'prophetic eyes' that 'The curtain has not yet risen for act one, but from your seat in the audience you can hear sounds behind the curtain. The stage is being set for the beginning of the play. The props are being put in place and the actors are taking their positions. These events are not the play itself; they are a natural, necessary preparation for it' ${ }^{60}$ The Rapture is transcendence of limit; the transcendent does not tackle the physical world like the struggle of the trangressive, it is rather a symbolic escape from

\footnotetext{
${ }^{58}$ Quoted in Ó Tuathail, Critical Geopolitics, p.42.

${ }^{59}$ F. L. Borchardt, Doomsday Speculation as a Strategy of Persuasion: A Study of Apocalypticism as Rhetoric (Lewiston: The Edwin Mellon Press 1990) p.224.

${ }^{60}$ Hitchcock, What on Earth is Going On? (Sisters, OR: Multnomah 2002) p.43 emphasis added.
} 
it. $^{61}$ The chimera of The Matrix style virtual reality seems to open-up possibilities for further making of 'geographies of evil' where a 'real' world could be replaced with a virtual one-just as the 'real' world will be replaced with a heavenly one following the Rapture $^{62}$ The ability to live in an ephemeral or inconsequential stage in history is the ability to construct it, while removing responsibility for it. ${ }^{63}$

Theatrical analogies are Hitchcock's preferred technology of separation from his own geopolitical interpretations, for 'if Bible prophecy had a list of credits, it would read "directed by God." As director and producer, God is orchestrating, organizing, and overruling world events to set the stage for a drama like no other. He is ensuring that all the players will be in place when the curtain goes up at the Rapture'. ${ }^{64}$ Hitchcock's theatrical metaphors make a visual spectacle of the world and therefore reduce the heteroglossia of everyday life to homogeneous space: a panoramic view from a panoptic perspective. This partitions the world into simple and easy-to-manage elements from which he monitors the whole world.

\footnotetext{
${ }^{61}$ D. Pettman, After the Orgy: Towards a Politics of Exhaustion (Albany: State University of New York Press 2002) p.39. See also M. Foucault, 'A Preface to Transgression', in D. Bouchard (ed.), Language, Counter-Memory, Practice D. Bouchard and S. Simon (trans.) (Ithica: Cornell University Press 1977) pp.29-52.

The Matrix directed by Andy Wachowski and Larry Wachowski (1999); D. Campbell, Writing Security: United States Foreign Policy and the Politics of Identity (Minneapolis: University of Minnesota Press 1998 [Originally published in 1992]) p.88. See also M. Wertheim, The Pearly Gates of Cyberspace: A History of Space from Dante to the Internet (New York: W. W. Norton 1999) pp.44-75 and 253-82.

${ }^{63}$ B. Diken, and C. B. Laustsen, '7-11, 9-11, and Postpolitics', Alternatives 29/1 (2004) p.104; See also S. Zizek, Welcome to the Desert of the Real (London: Verso 2002).

${ }^{64}$ Hitchcock, The Coming Islamic Invasion of Israel, p.22.
} 


\section{Act 2:}

Seeing the Whole Picture

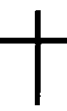

For Hitchcock there is a panoptical all-seeing, omnipotent, vengeful deity: God. But through Hitchcock, as well as through other prophecy writers, the all-seeing panopticon is inverted to the premillennialist of the spectacle. God remains the omnipotent one but Hitchcock grants himself, often taking the cue from his prophecy peers and predecessors, the ability to distance himself from the 'geo' to 'graph' it. Where still the object of surveillance, now the subject too is the all-seeing centre by "holding the world at a distance'. This strategy to write the geography of the world is explored in the first section of this chapter. It strives to remove this privileged position from Hitchcock by rewriting his text not as the geo-graphy of the Bible but rather the geo-politics of Hitchcock. It outlines the strategy that privileges geography over history. This geographical emphasis allows prophecy expounders to capitulate with the old maps of the Apocalypse by disregarding the past and legitimate a new one as the true dictation of God. The order of navigating linear time is the act of having something to look forward to. However, the future is not 'the unexplored territory of potentiality' as Pettman notes, for premillennialists it is known. ${ }^{1}$ This 'known' future breathes truth and acceptance into the theatrical analogy for the script is already written and simply needs to be performed, rehearsed and ultimately played out on stage Earth.

\footnotetext{
${ }^{1}$ D. Pettman, After the Orgy: Towards a Politics of Exhaustion (Albany: State University of New York Press 2002) p.XI.
} 
The second section looks at the history of Christian Apocalyptic geopolitics by making plain their politically influenced justifications for dividing the world apocalyptically. The historical focus is on the shifting 'Evil' character, from Russia to that of the Middle East. These geopolitical shifts are important in showing Hitchcock's antecedents and influences, particularly in relation to the post-Cold War foreign policy of the United States and also the importance that Hitchcock has in this transition as the 'reterritorializing prophet' of prophecy. Such a shift also asks the question, if prophecies can be applied with equal validity to any historical situation, how is it that premillennial followers do not question divinely inspired foretellings of specific events as political? It is argued that geography is used as atemporal frames of truth over the questions history would pose. As Sacvan Bercovitch describes the American Jeremiad: 'a ritual designed to join social criticism to spiritual renewal, public to private identity, the shifting 'signs of the times' to certain traditional metaphors, themes and symbols' which make normative geopolitics to make sense of the changing international scene and America's role in it. ${ }^{2}$ These geographic signs are politically selected, shaped, and arranged to perform their signifying function in the prophecy scenario.

The third section compares the Cold War prophecy of Hal Lindsey, Tim LaHaye, and John Walvoord to the writings of Mark Hitchcock. Paul Boyer's (1992) major historical work on prophetic thought in America was published too early to thoroughly examine premillennial dispensationalism's most recent imagination as to where evil impiety resides. He writes of Russia's declining importance; 'in view of the prophecy writers' resourcefulness and long experience at adapting to changing realities...this

\footnotetext{
${ }^{2}$ S. Bercovitch, The American Jeremiad (Madison: University of Wisconsin Press 1978) p.XI. quoted in J. Sharpe, Condensing the Cold War: Reader's Digest and American Identity. (Minneapolis: University of Minnesota Press, 2000) p.166.
} 
restructuring will probably be successfully accomplished' ${ }^{3}$ It offers a comparative cultural history of the protean geopolitical boundaries of dispensationalists, particularly that of Hitchcock, and their historical relation to American foreign policy and cultural ideology of the world east of Western Europe from 1970 to 2005. This is important in regrounding the work of Hitchcock from his transcendent position to politically contingent prophecy. Further, the importance of geographic inquiry into such matters is important in its ability to illuminate the 'power/knowledge' influence that geographical imaginations have on politics and people at all scales.

\section{Privileging the Geo: Distancing, History, and Representation}

Hitchcock uses his author-itative strategy to take his readers on what he calls a "quick glance at the bigger picture'. It is this Biblical association that allows him to transcend the spatial limits and complexities of everyday life and to envision the world as a complete and comprehensible whole. ${ }^{5}$ Making geography 'obvious' and 'natural' is made cogent through an astuteness to fore-sight. This 'sight' helps Hitchcock segregate what is permanent and what is ephemeral, what is God's move and what is human induced, what is a sign and what is not.

Agnew explains that it is in part because of a 'commitment to this or that ideology (apocalyptic Christianity, microeconomics, etc.) that does not require knowledge of real places' that abstractions about the world can be made. ${ }^{6}$ It is 'utopian' to lay claim from

\footnotetext{
${ }^{3}$ P. Boyer, When Time Shall Be No More: Prophecy Belief in Modern American Culture (Cambridge, Mass: Harvard University Press 1992) p.180.

${ }^{4}$ M. Hitchcock, The Second Coming of Babylon (Sisters, Ore.: Multnomah Publishers 2003) p.26.

5 J. Agnew, Geopolitics: Re-visioning World Politics (London: Routledge 1998) p.11.

${ }^{6}$ J. Agnew, 'Commentary III: Learning From the War on Iraq', The Arab World Geographer 6/1 (2003). Available at: [http://users.fmg.uva.nl/vmamadouh/awg/forum3/agnew.html].
} 
'nowhere' to the geography that lay outside the United States. It is this tabula rasa, the 'nowhere', which make abstract and fictitious representations of the geography 'out there' justifiable, reasonable, and normal. Circumnavigating the complexities of the local gives way to a generalizing and transcendant 'Jesus-trick' process, as Sparke calls it, that enables Hitchcock to predict the future with no regard to its dehumanizing consequences. ${ }^{7}$ Representations of the 'Muslim world', 'Roman Empire', and Russia all make possible the dystopic categories and known justifications for wars that span entire continents of people based on ludicrous claims that they are all the same: Just enemies. The 'news from nowhere' allows Hitchcock to construct his world, his monologue, 'utopia/dystopia', and 'nowhere/where'. Indeed, they are one person's view built from 'current events...[that]', for him, 'provide discernable signs of the [end] times'. ${ }^{8}$ These are events that have been selected and 'picked over' to fit his imagined map.

Once transcendent from the world, it can be seen in totality and understood from the privileged seat as a Holy ordained interpreter and Raptured Christian. As Heidegger put it, 'the world conceived and grasped as a picture'. Without separation from the picture it is impossible to grasp the whole in part because one is a part of the whole. Through the Rapture and the Biblically inspired text there is simultaneously a separation of the self and a separation of the group. Seeing the world as a whole allows one to create a system upon the world crystallizing it geographically into cells apart from, and prior to, the objects it contains. Thus, the Bible has always referred to this geographic structure prior to political discourses that see, in this case, Muslims geo-graphed as evil: it is a

\footnotetext{
${ }^{7}$ M. Sparke, In the Space of Theory: Postfoundational Geographies of the Nation-State (Minneapolis: University of Minnesota Press, 2005) p. 308.

${ }^{8}$ M. Hitchcock, What on Earth is Going On? (Sisters, OR: Multnomah 2002) p.46.

${ }^{9}$ Quoted in D. Gregory, Geographical Imaginations (Oxford: Blackwell 1994) p.34.
} 
timeless representation. For Mark Hitchcock, the 'signs are everywhere', and interpreting them is 'like staring at a table covered with pieces of a jigsaw puzzle', ${ }^{10}$ where the Bible is the picture on the box and the pieces are planet Earth. The jigsaw puzzle analogy suggests prophecy's layperson accessibility, and if correctly assembled, will reveal a singular meaning and structure to geography.

Agnew (1998) suggests that geopoliticians use history to "justify their decisions as if history simply repeated itself without the necessity of geographically informed judgments about the character of different world situations'. ${ }^{11}$ Dispensational seers identify 'spaces of evil' based on historical presuppositions, and do so in relation to the specious enemy of the (United) State(s). Dispensationalists justify history via spatial (re)representations of Formal, Popular, and Practical geopolitics through a particular reading of the Bible. Lindsey's (2002) claim to a historically ever-present and 'Everlasting Hatred' between Muslims and Judeo-Christians is an example of Agnew's claim to a historical template from which to generalize and graft people as antipodal opposites on a map of 'hatred'. ${ }^{12}$ This always written and everlasting hatred is in many ways an Orwellian double-speak strategy: Oceania has always been at war with Eurasia. ${ }^{13}$ In terms of Muslims, God has had always been at war with Muslims. To premillennialists, writes George Marsden, 'all that is significant about history can be found in the Bible. There, the pattern of history of all the coming ages was written in advance... Modern history is of interest only as it produces some facts that document the

\footnotetext{
${ }^{10}$ Hitchcock, The Coming Islamic Invasion of Israel (Sisters, OR: Multnomah 2002) pp.23-4.

${ }^{11} \mathrm{~J}$. Agnew, Geopolitics, p.4.

${ }^{12}$ H. Lindsey, The Everlasting Hatred: The Roots of Jihad (Murrieta, CA: Oracle, 2002), pp.230-31.

${ }^{13}$ Winston remembered that, 'Oceania, four years ago, had been at war with Eastasia and at peace with Eurasia' however Julia could only recall that 'we'd always been at war with Eurasia'. G. Orwell, 1894 (New York: The New American Library, 1961 [Originally published in 1949) p.127.
} 
cultural decline predicted in the Bible.' However, the geographical crystallizations, most notably Israel, do have modern historic significance but only in as far as they illuminate geography. Marsden continues in this vein that history becomes, then, 'basically a matter of collecting and classifying facts that fit the biblically derived pattern'. ${ }^{4}$

The dispensational understanding of history is made possible by the assumption that any biblical map drawn or described is the true map of the world, taking advantage of the ostensible pedagogy that 'a map never lies' and is the exact representation of the way the world really is. ${ }^{15}$ Prophetic history is not to be foretold by prophecy expounders before the Rapture; Christ makes clear and warns that 'Of that day and hour knoweth no man' (Matthew 24:36) and 'it is not for you to know the times or the seasons, which the Father hath put in his own power' (Acts 1:7). ${ }^{16}$ History is, then, not a sign of the End Times; rather the signs are the geopolitical expressions of the world. Geography is privileged in dispensational geopolitics whereas history is downgraded as an explanatory teleology: the temporal is subsumed by the spatial. This allows believers to disregard history and maintain their belief without contradiction to their believed inerrancy of the Bible or scepticism as to the accuracy of their author-itative exegeses. It is then through the geography of the Bible, that is, the 'nations' mentioned therein that one could begin to build a prophetic history.

\footnotetext{
${ }^{14}$ G. M. Marsden, (eds.) 'Evangelicals, History and Modernity', in Evangelicalism and Modern America (Grand Rapids: Eerdmans, 1984) p 96 and 99.

${ }^{15}$ See J. B. Harley, 'Deconstructing the Map', in T. Barnes and J. Duncan (eds.) Writing Worlds: Discourse, Text and Metaphor in the Representation of Landscape, (London: Routledge, 1992).

${ }^{16}$ This is not to say that the 'Olivet Discourse' (Matt. 24:36), in which Christ warned his disciples on the Mount of Olives not to distract themselves looking for the signs of his Coming, prevented prophecy expounders from date setting. Many did, often using complex mathematical equations. Hal Lindsey, for example, predicted the end would come in 1988. Between 1642 and 1660, England experienced Civil War, end-time anticipation was rife. William Sedgwick, during England's Civil War, for example, predicted the end in two weeks, an act that later earned him the lifelong nickname 'Doomsday Sedgewick'. Boyer, When Time Shall Be No More, p.64.
} 
The disciplinary power that de Certeau refers to as strategies serve to recentre the prophetic system of naming. In this sense Hitchcock's premillennialism is very much contingent, taking purchase in a common fight, a common enemy and ultimately a strategy to make a meaningful truth through faith, and having faith in faith as though that truth was unproblematically set down by God. To make the world intelligible from the perspective of biblical toponyms, the process of naming in religious terms is important; often state and regional borders take on biblical ones and vice versa. 'In the beginning,' as Gunnar Olsson writes in reference to Genesis, 'nothing exists because nothing was named. All that exist are two coordinates, above and below' ${ }^{17}$ Naming and renaming is making familiar the unfamiliar and also brings the world into textual presence by closing the gap between the word and the place it represents. This space had to be written in biblical terms before it could be interpreted. In Lefebvre's terms, 'space had to be produced before it could be read'. ${ }^{18}$ This act of naming is not merely describing the place but also constitutes the subject of the act of naming it. It's a colonization by representation: a non-physical colonization, that may have 'physical' results as is the colonization of Iraq and support for Israel. As such, this epistemological strategy of textualizing space in biblical terms can make it knowable as though the Bible was a Western, English, Orientalist text. It is this act of 'naming' and 'renaming' throughout prophetic history and through the act of distancing that is of interest. The prophetic realm is ever-changing and boundaries that 'contain' these processes are not simply permeable or contingent, but very much part of dynamic, and historically traceable, prophetic ontology. To understand the changing prophetic map to be political is an act of

\footnotetext{
${ }^{17}$ G. Olsson, 'Placing the Holy', in T. Mels (eds.) Reanimating Places: A Geography of Rhythms (Burlington, VT:Ashgate, 2004) p205.

${ }^{18}$ H. Lefebvre, The Production of Space (Oxford: Blackwell, 1991) pp. 142-43.
} 
transgression, ushering Hitchcock from his seat in Heaven to the stage on Earth. In the apt words of Agnew and Corbridge (1995), 'to understand the world, therefore, requires that we understand its changing geography'. ${ }^{19}$

\section{A Short History of Premillennial Geopolitics}

It can be said that the Biblical 'Gog' and 'Magog' were usually places of mystery set in opposition to what was known. ${ }^{20}$ Though the specific locations (which are often confused as 'nations') have changed frequently throughout history-the Huns, the Mongols, the Arabians, the Magyars, and the Turks - they were usually drawn east of Western Europe. To various medieval cartographers, Magog and Gog were the tribes of and beyond the Caucasus mountains. ${ }^{21}$ By the $13^{\text {th }}$ century with the ensuing Crusades and into the lateseventeenth-century, Gog represented the Ottoman Empire to most of continental Europe and England. However, Islam and the Middle East never won the unanimous support as Gog that the Soviet Union did during the Cold War.

Russia's association with Rosh, Magog, Gomer, Beth-togarmah, Tubal, and Meshech, all of which will be ruled under the leadership of Gog, has its beginnings in Wilhelm Gesenius's musings on the modern toponyms of the Bible. ${ }^{22}$ This conflation was popularized in the United States with the help of Darby's missions there (1859-1882). After the Russian Revolution (1917) and the onset of the Cold War (1946), the Soviet Union would remain in the spotlight for 45 years as premillennial dispensationalism's evil atheist enemy.

\footnotetext{
${ }^{19}$ For a more complete discussion, see J. Agnew and S. Corbridge, Mastering Space: Hegemony, Territory and International Political Economy (London: Routledge, 1995) 13-14.

${ }^{20}$ Boyer, When Time Shall Be No More,pp.152-53.

${ }^{21}$ Ibid, p. 153 .

${ }^{22}$ Ibid, p.154.
} 
Understanding the historical context from which Gesenius, a professor of theology at the University of Halle in Prussia, identified 'Rosh' as Russia, 'Tubal' as the Siberian capital 'Tobolsk' and 'Meshech' as 'Moscow' in his 1828 lexicon, is key in showing how the territorial politics of the day would influence biblical geography. After the Treaty of Tilsit (1807), which reduced Prussia's territory, Russia was deemed by Prussians as the evil referred to in the Bible. ${ }^{23}$ And for Darby, the Crimean War further exacerbated Russia's 'evil' character in England. This is not to say that these were the sole determinative reasons for identifying 'Rosh' with Russia; certainly linguistic similarity was also a factor. Therefore Russia as a historical template and association with the many names in Ezekiel 38 and 39 was cast one-hundred years before the Cold War; however, Cold War geopolitical and geoeconomic reasoning practices helped to further colour the prophetic spaces left blank in these times.

On the whole, mappa mundi of the Apocalypse have changed very little in a millennium. Medieval ' $\mathrm{T}$ and $\mathrm{O}$ ' maps, which rotated upon the geographical axis of Israel, divided the world into three regions, often defined by Noah's three sons who are said to have fathered the three races of humans after the great flood: Japheth was Europe at the lower right region, Ham was Africa at lower left, and Shem occupied the upper half of the circle as Asia (see Figure 8 ). ${ }^{24}$ Using evidence gathered by Gesenius, John Cumming, and the fifth-century BC Greek geographer Herodotus, Hal Lindsey, in his best-selling book The Late Great Planet Earth (1970) that sold more than forty-million

\footnotetext{
${ }^{23}$ D. Wilson, Armageddon Now! The Premillennial Response to Russia and Israel Since 1917 (Grand Rapids, MI: Baker, 1977) pp.151-53.

${ }^{24}$ See D. Woodward, 'Medieval Mappaemundi', in . J. B. Harley and D. Woodward (eds.) The History of Cartography, Volume 1 (Chicago: University of Chicago Press, 1987) pp.286-370.
} 
copies, outlined 'four spheres of political power'. ${ }^{25}$ The first was the 'King of the West' which were the nations that made up the European Economic Community or 'Roman Empire' (Daniel 9:26); the second was the 'King of the North' which was the Soviet Union (Daniel 11:40); the third was the 'Kings of the East' which were China and possibly Japan and India (Revelation 16:12); and the forth was the 'King of the South', which was Africa and Iran, and possibly other Muslim nations (Daniel 11:40). Lindsey's modern prophetic map has further divided the world by attributing Japheth, Ham, and Shem's sons (Genesis 10:2) to nation-states within the larger blocks and he added the region that has been deemed the 'Kings of the East'.

Figure 8

\section{EARLY 'T AND O' MAPS}

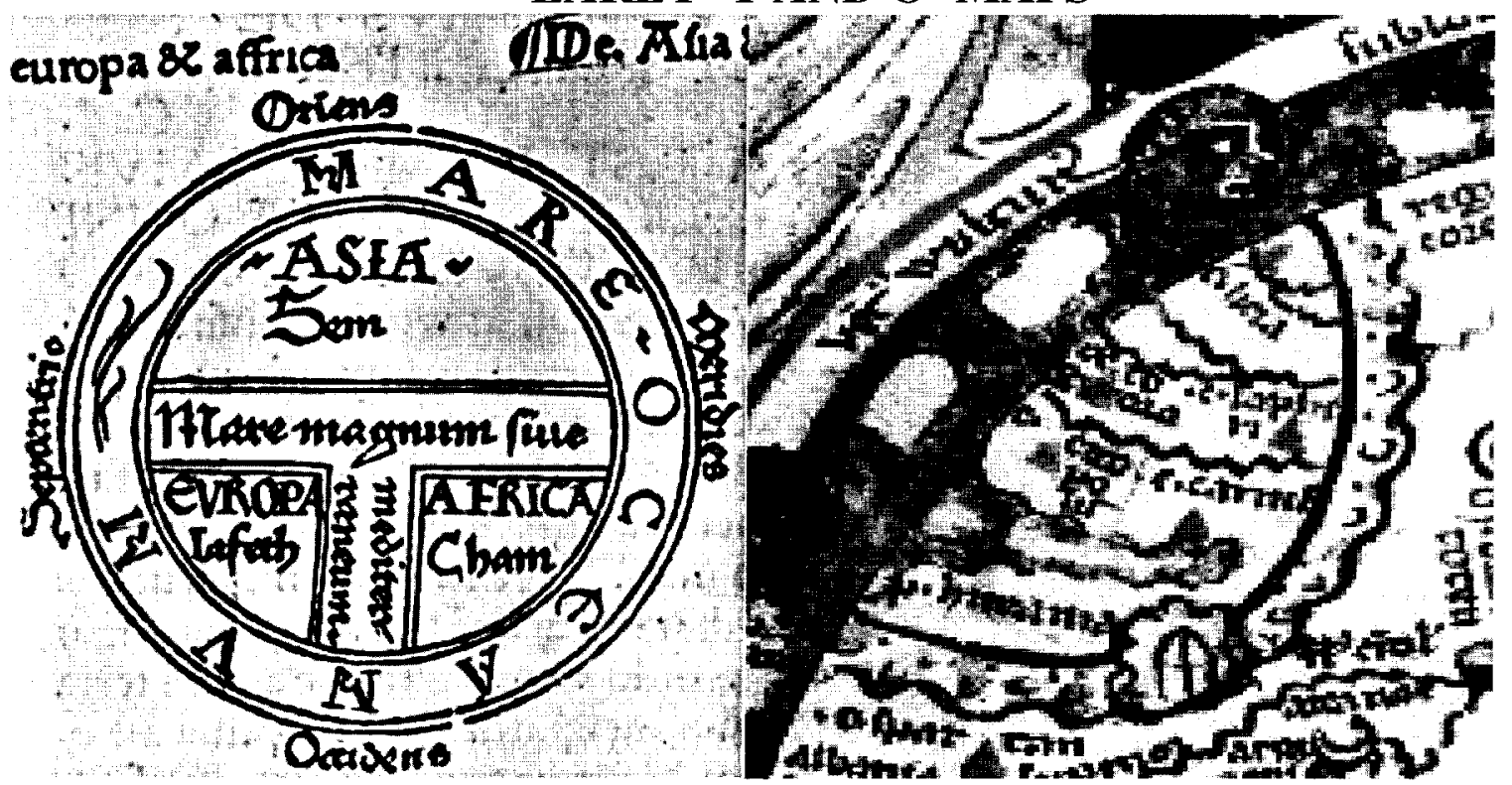

The map on left, by Guntherus Ziner, Augsburg (1472), is a classic example of a 'T and O' map. Similar maps have been dated as far back as 730CE. The Psalter Map on the right (circa. 1260) shows Gog and Magog trapped behind 'the Gates of Alexander'. See D. Woodward, 'Medieval Mappaemundi', (1987) pp.286-370.

\footnotetext{
${ }^{25}$ H. Lindsey, The Late Great Planet Earth (Grand Rapids, MI: Zondervan Books, 1970) pp.69-70 and 42; W. Gesenius, Gesenius' Hebrew and Chaldee Lexicon. Samuel Tregelles (trans.) (Grand Rapids, MI: Wm. B. Eerdmans, 1949).
} 
Lindsey's amended 'power blocs' are still used to outline the post-Cold War prophetic scenario by LaHaye, Dyer and Hitchcock; it is only the nations that make up these 'power blocs' and thus the boundaries of the blocs that have changed. For Lindsey it was not so much a change in place names, but rather a change in emphasis from Russia to the Muslim Middle East. Prophetic geographies are generally not discarded; they are simply re-sign-ified or reterritorialized to positions relative to current events. They elevate that which fits and abandon that which does not-Russia was too crucial in prophetic history to be dropped immediately following the Cold War. Lindsey's shifting emphasis from Russia to the Muslim Middle East is obvious in his recent books on the subject, where he re-identifies the 'King of the South' as 'the Muslim sphere of power' rather than his previously predicted 'African Alliance., ${ }^{26}$

The determinism of Lindsey's claim that 'Russia is a Gog' is strengthened by him when he quotes Israeli General Moshe Dayan (1915-1981) that 'the next war will not be with Arabs, but with Russians' ${ }^{27}$ Similarly LaHaye, in 1974, even went so far as to give reasons why Russia and not the Middle East was a harbinger sign of the End Times: 'the present Middle East crisis is not...predicted for the end time [because] Egypt, a prominent ally of Russia today, is not listed in the group'. ${ }^{28}$ This is all placed in stark contrast to both Lindsey and LaHaye's later focus on the coming Islamic invasion. For example, Lindsey wrote in 2002 , that 'the last war will begin with a coordinated attack against Israel by the Iranian led Muslim forces joined by Russia'. ${ }^{29}$ The invasion is no longer led by Russia; instead it is 'joined' by Russia and led by 'Muslim forces'.

\footnotetext{
${ }^{26}$ Lindsey, The Everlasting Hatred, pp.230-231.

${ }^{27}$ Lindsey, The Late Great Planet Earth, p.59.

${ }^{28}$ T. LaHaye, The Beginning of the End (Wheaton, IL: Tyndale, 1972) p.73.

${ }^{29}$ Lindsey, The Everlasting Hatred, p.235
} 
The change from the Soviet Union to the Middle East was a gradual one beginning with the 1973 oil crisis and later with the Iranian Revolution. In Lindsey's major follow up to The Late Great Planet Earth in 1980, he writes the 'backward and underdeveloped Arab nations... will gain more power to control the world situation' with the 'power of oil' ${ }^{30}$ However, consistent with his earlier musings, he adds that 'the power of Russia' will still be the major force in the invasion of Israel. This change was no doubt influenced by Walvoord's 1974, Armageddon: Oil and the Middle East Crisis which outlines the rising power of the Middle East and Muslims in particular. Walvoord, former president of the Dallas Theological Seminary where Lindsey obtained a Th.M. and Hitchcock obtained a Ph.D., observed what he called 'Russia's Downfall', and continued that the 'dramatic realignment of political and economic power on the international scene is already in the making... The power of Arab oil and European agriculture and industry may lead to a cartel that will eventually eclipse the power of both Russia and the United States in the Middle East'. ${ }^{31}$ Prophecy books increasingly emphasized Islam as evil in these times. However, Lindsey's clear obsession with Russia's prophetic role has continued to influence many contemporary prophecy writers. Boyer, in this respect, confirms that premillennial dispensationalists will be among the last people in the United States to admit the Cold War is over. ${ }^{32}$

\footnotetext{
${ }^{30}$ H. Lindsey, The 1980's: Countdown to Armageddon (King of Prussia, PA: Westgate, 1980) p.57 and 68.

31 J. F. Walvoord, Armageddon: Oil and the Middle East Crisis (Grand Rapids, MI: Zondervan, 1974) p. 125 and 20.

${ }^{32}$ Boyer, When Time Shall Be No More, p. 180.
} 


\section{Hitcheock and the New Apocalyptic Picture}

The Soviet 'Empire' met its demise through secular means and not by the hoped and predicted biblical Armageddon. Many prophecy scholars thought it was an ephemeral decline while others denied the evidence and advised their readers to 'not believe everything they read' ${ }^{33}$ Most, however, shifted their analysis to new geographical spheres, mainly the Islamic Middle East, after the 1990 Iraqi invasion of Kuwait. Unlike Lindsey whose prophecy was centered on Russia, Hitchcock's prophetic geography is about: 'Muslims, Muslims, and More Muslims'. 34

Hitchcock admits that prophecy has undergone a geographical shift since the end of the Cold War. In After the Empire (1994), he writes, 'the purpose of this book, therefore, is to take a fresh look at Ezekiel 38 and 39 and to let the true God speak'.35 Hitchcock retraces all of the biblical names of Ezekiel 38 and 39 and restructures Lindsey's entire geopolitical order. In this respect he writes, 'All of the names mentioned in Ezekiel 38-39 are presently within the geographical boundaries of Islamic nations...The Soviet Union has fallen, and Islam seems to be moving in to fill the vacuum'. ${ }^{36}$ In 1993 , Hitchcock wrote in contrast to the earlier work of Lindsey that the Communism of the Soviet Union was a 'constraint on fundamentalist, radical Islam' and therefore a constraint on prophecy fulfillment. ${ }^{37}$

His timely 'truth' that Babylon will again rise on Iraqi soil, for example, stems from his selected and conjectural images of the War in/on Iraq, where 'evil will be

\footnotetext{
${ }^{33}$ T. P. Weber, On the Road to Armageddon: How Evangelicals Became Israel's Best Friend (Grand Rapids, MI: Baker Academic, 2004) p.204.

${ }^{34}$ Chapter 6 title, in M. Hitchcock, After the Empire: Bible Prophecy in Light of the Fall of the Soviet Union (Wheaton, IL: Tyndale, 1994) p.69.

${ }^{35}$ Ibid., XI and XIII.

${ }^{36}$ Ibid., 9.

${ }^{37}$ M. Hitchcock, The Silver Kingdom: Iran in History and Prophecy (Oklahoma City: Hearthstone, 1993) p.4.
} 
uniquely focused in one geographic location... Babylon'. ${ }^{38}$ The rise of Babylon is the lacunae of premillennial prophecy. Hitchcock's premillennial gendered mythology of Babylon as the seducer, prostitute, and Harlot represents the antithesis of his Go(o)d beliefs. ${ }^{39}$ Babylon, which was traditionally to be understood as apostasy and Satan's religion, has also changed. To Lindsey, however, Babylon was Rome: 'there is no question about where the city [of Babylon] will be-it was Rome'. ${ }^{40}$ Given the recent wars in/on Iraq and rumours of Saddam Hussein's regime rebuilding the city of Babylon, a preferred literal reading of the Bible was then made possible. Dyer was perhaps best known for this reterritorialization of this sign. Dyer writes that Babylon is 'the geographical " $\mathrm{X}$ " and "we might conclude that the major end time evil empire would be centered in the Middle East in the country of Iraq, in the city of Babylon' ${ }^{41}$ This idea would later be shared by Hitchcock and others, such as the Left Behind series founders: LaHaye and Jenkins. Left Behind, a series that has sold more than sixty-million copies in ten-years, locates the Antichrist Nicolae Carpathia's Roman Empire head-quarters in the New Babylon in Iraq. ${ }^{42}$ However, Lindsey's Late Great Planet Earth didn't mention Iraq and his book The 1980 s predicted that it would become part of Syria. ${ }^{43}$ Given the recent regime change in Iraq the chances of Babylon being rebuilt are slim. Dyer argues in this case that 'if Hussein disappears tomorrow from the international scene, someone else will

\footnotetext{
${ }^{38}$ M. Hitchcock, The Second Coming of Babylon (Sisters, Ore.: Multnomah Publishers 2003) p.93.

${ }^{39}$ For a post-structuralist critique of apocalyptic thought using sexuality, see D. Pettman, After the Orgy: Towards a Politics of Exhaustion (Albany: State University of New York Press 2002). For a feminist and gendered critique of apocalyptic thought see L. Quinby, Anti-Apocalypse: Exercises in Genealogical Criticism (Minneapolis: University of Minnesota Press 1994).

${ }^{40}$ Ibid., 133; Many have thought the United States was Babylon, see Jack Van Impe, The Great Escape (Nashville, TN: Word, 1998), 207.

${ }^{41}$ C. Dyer, The Rise of Babylon: Is Iraq at the Center of the Final Drama? (Chicago: Moody, 2003 [originally published in 1991]) p.21 and 161; For satellite images of the rebuilding of Babylon see plates between pages 96 and 97 .

${ }^{42}$ T. F. LaHaye and J. B. Jenkins, Left Behind: A Novel of Earth's Last Days (Wheaton, IL: Tyndale House, 1996).

${ }^{43}$ Lindsey, The 1980 's, p.68.
} 
pick up the battle cry. And there will be one more martyr to the cause of Arab unity ${ }^{4}{ }^{44}$ Quoting Morris, Hitchcock concludes that Babylon's location is the best commercial location in the world for the Antichrist to rule the world:

Computer studies from the Institute of Creation Research have shown, for example, that Babylon is very near the geographical center of all the Earth's land masses. It is within navigable distance to the Persian Gulf and is at the crossroads of the three great continents of Europe, Asia, and Africa. Thus there is no more ideal location anywhere for a world trade center... a world capital! ${ }^{45}$

This type of geopolitical reasoning mirrors Mackinder's thoughts of a centrality of place to distribute the world's goods on the 'world island'. However, Iraq is virtually landlocked and has only twenty-six miles of coastline on the Persian Gulf and Basra acts as its inland port which lies fifty miles from the Shatt al Arab waterway.

The Biblical territory 'Gomer', was thought during the Cold War to be East Germany specifically and the regions of Eastern Europe swallowed by the Soviet Union after World War II more generally. For Lindsey, Gomer's location made good (American) sense in the historical and geopolitical context of the Cold War. However, more recent scholars have revisited the origins of these toponyms in light of a changing political landscape. As early as five years after the Cold War, Hitchcock relocated Gomer to 'Muslim Turkey'. ${ }^{46}$ LaHaye, one of the proponents of this new geographical positioning of Gomer as Turkey, in 1972 sided with Lindsey quoting him that indeed Gomer 'is in the area of modern Poland, Czechoslovakia, and East Germany' ${ }^{47}$

Although Hitchcock continues to include Russia as part of 'Rosh', his books are imbued by ideological currents and political events that have vilified Islam. For

\footnotetext{
${ }^{44}$ Dyer, The Rise of Babylon, p.126.

${ }^{45}$ Hitchcock, The Second Coming of Babylon, p.107.

${ }^{46}$ Hitchcock, The Coming Islamic Invasion of Israel, 48.

${ }^{47}$ LaHaye, The Beginning of the End, 68.
} 
Hitchcock, extracting from academia, the media, and political leaders to make generalizations of the world, is a Divine and simple task: 'Our task is to determine which countries inhabit these ancient lands today. The where question is easy' and the 'who are the specific nations that will participate in this invasion'. ${ }^{48}$ In his book, The Coming Islamic Invasion of Israel (2002) he outlines what he calls 'God's "Top-Ten Most Wanted List"' and compares it to President George W. Bush's 'axis of evil': Rosh (Russia), Magog (Central Asia), Meshech (Turkey), Tubal (Turkey and southern Russia), Persia (Iran), Ethiopia (Sudan), Put (Libya), Gomer (Turkey), Beth-togarmah (Turkey), and 'many peoples with you' (other Islamic nations) that could possibly be Iraq, Syria, Jordan, and Egypt (see Table 1). ${ }^{49}$ His reason for listing these nations becomes clear when he writes that 'all of...[which, with the exception of Russia] have one thing in common: Islam, ${ }^{50}$

Table 1

CHANGING PREMILLENNIAL TOPONYMS (1970-2005)

\begin{tabular}{|c|c|c|c|}
\hline $\begin{array}{l}\text { Biblical } \\
\text { Place }\end{array}$ & $\begin{array}{l}\text { Cold War } \\
\text { Association }\end{array}$ & $\begin{array}{l}\text { Post-Cold War } \\
\text { Association }\end{array}$ & $\begin{array}{l}\text { Geopolitical } \\
\text { Power Bloc }\end{array}$ \\
\hline Rosh & Russia & Russia & \multirow{6}{*}{ King of the North } \\
\hline Magog & Russia & (Muslim) Central Asia & \\
\hline Meshech & Moscow, Russia & Turkey & \\
\hline Tubal & Tobolsk, Russia & Turkey and Iran & \\
\hline Gomer & $\begin{array}{l}\text { Eastern Europe and } \\
\text { East Germany }\end{array}$ & Turkey & \\
\hline Beth-togarmah & southern Russia & Turkey & \\
\hline Persia & Iran & Iran & \multirow{4}{*}{ King of the South } \\
\hline Ethiopia & black Africa & Sudan & \\
\hline Put & $\begin{array}{l}\text { Libya, Algeria, Tunisia } \\
\text { and Morocco }\end{array}$ & Libya & \\
\hline $\begin{array}{l}\text { Many Peoples } \\
\text { with you }\end{array}$ & Egypt & $\begin{array}{l}\text { Iraq, Syria, Jordan } \\
\text { and Egypt }\end{array}$ & \\
\hline Babylon & Rome & Babylon, Iraq & King of the West \\
\hline
\end{tabular}

The Cold War associations are shared by both Lindsey and LaHaye, while the Post-Cold War associations are shared by Hitchcock, Dyer and LaHaye.

\footnotetext{
${ }^{48}$ Hitchcock, The Coming Islamic Invasion of Israel (Oklahoma: Hearthstone Publishing 2002) p.25.

${ }^{49}$ See ibid, pp.27, 59, and 32-33.

${ }^{50}$ Ibid, 32-33.
} 
Turkey (Meshech, Tubal, Gomer, and Beth-togarmah), for Hitchcock, is vastly overrepresented as to where the geographic concentration of Muslim 'evil' resides. But he contends, though moderately Muslim, we should not forget that 'Turkey is still a Muslim nation' and because of that we should not underestimate their capacity for 'evil' ${ }^{51}$ Furthermore, his autocratic certainty does not problematize the political present with 'Gomer', which during the Cold War was thought to be Eastern Germany by Hal Lindsey and Wilhelm Gesenius. ${ }^{52}$ Nor does he problematize the present with Lindsey's dogmatic belief that Babylon was Rome. ${ }^{53}$ For Lindsey and Gesenius, it was the geography that fit Cold War politics and Hitchcock has transposed this geography to fit with the current political situation. ${ }^{54}$ Hitchcock justifies his geopolitics: 'This list of nations reads like the headlines of this week's newspaper. It's not too difficult to imagine these nations conspiring to invade Israel in the near future. And according to God's Word, that is exactly what they will do. It could be very soon'. ${ }^{55}$ Believing that the media had proved his exegesis correct, he has shown for the critical scholar that his prophetic analysis is deeply political—contingent on the current 'enemies of his state' and political

\footnotetext{
${ }^{51}$ Ibid, p.48.

${ }^{52}$ H. Lindsey, The Late Great Planet Earth (Grand Rapids, MI: Zondervan Books 1970) pp.69-70; W. Gesenius, Gesenius' Hebrew and Chaldee Lexicon S. P. Tregelles (Trans.) (Grand Rapids, MI: Wm. B. Eerdmans, 1949) pp.752.

${ }^{53}$ Hitchcock, The Coming Islamic Invasion of Israel, pp.107-108. Many have thought America was Babylon, see S. F. Logsdon, Is the U.S.A. In Prophecy? (Grand Rapids, MI.: Zondervan 1965) p.9, and J. V. Impe, The Great Escape (Nashville, TN.: Word 1998) p.207.

54 'Rosh' in most Bibles (KJV, NLT, NIV, the Revised Standard Version, and the New American Bible) is an adjective meaning 'chief'. However, Hitchcock, Lindsey, Dyer, and many other premillennialists, see 'Rosh' as a proper noun (as written in the NAS, the Jerusalem Bible, and the New English Bible). Hitchcock denies that his conflation of 'Russia' with 'Rosh' is derived from alphabetic similarity. See Hitchcock, The Coming Islamic Invasion of Israel, p.39. Furthermore, Meshech and Tubal, though popularized in the Scofield Study Bible (KJV) to be Moscow and Tobolsk by virtue of their similarity, are to Hitchcock incorrect interpretations and are actually part of Turkey. And last, Hitchcock parallels 'Cush' with modern Sudan, though the King James Version translates it as Ethiopia, and Gesenius translates it as 'Black Africa', where Sudan is almost half Arab with a Sunni Muslim majority which conveniently fits with Hitchcock's 'Islamic alliance' formulation.

${ }^{55}$ Hitchcock, The Coming Islamic Invasion of Israel, p.60.
} 
time(s). The security of premillennialism is dependent on making the Bible fit with popular geopolitical fabrications, wars, and strife. Hitchcock's writing is reactionary by holding to tangible geographical spaces from which to find his signs. His work is making the world in the "image of his maps', ${ }^{56}$ but is also about rereading the Bible to make global politics the geopolitics of God.

In tracing the genealogy of Magog, Hitchcock asks, 'Who are the peoples who inhabit the ancient territory of these barbaric savages today?' and answers, 'Kazakhstan, Kirghizia, Uzbekistan, Turkmenistan, Tajikistan, and the Ukraine. All of these former republics, which are now independent nations, are Muslim nations except the Ukraine' ${ }^{57}$ Ethiopia, to Hitchcock is Sudan and not 'Black Africa' as both Gesenius and Lindsey had claimed. As Hitchcock endlessly states, Sudan is 'one of only three Muslim nations in the world with a militant Islamic government'. ${ }^{58}$ 'Put' to Hitchcock, is Libya: 'it takes no great imagination to conceive that Libya would join with the other nations' as 'Arabic is the official language of Libya, and the official religion is Islam'. ${ }^{59}$ Though China was to be the leader of the Kings of the East to Lindsey, Hitchcock does not mention it explicitly. To him, the Kings are first and foremost nations with large Muslim populations: 'India, Afghanistan, Pakistan, and all the nations of the Orient, or Far East' ${ }^{60}$ To Lindsey, the Euphrates River had marked the division between the East and the West. Therefore all of the nations east of the Euphrates (with the exception of Iran) were part of the Kings of the East. ${ }^{61}$

\footnotetext{
${ }^{56}$ G. O Tuathail, Critical Geopolitics: The Politics of Writing Global Space (Minneapolis: University of Minnesota Press 1996) p.20.

${ }^{57}$ Hitchcock, After the Empire,pp.23 and 26.

${ }^{58}$ Ibid., 79.

${ }^{59}$ Ibid., 85.

${ }^{60}$ Ibid., 149.

${ }^{61}$ Lindsey, The Late Great Planet Earth, p.81.
} 
Premillennial geopoliticians will find what they want to find in the Bible when compared to contemporary American foreign policy-from the Cold War to the Iraq wars, the dualisms (communist/capitalist and Muslim/Christian) are readily imagined for premillennialists to use. His reading that 'The Russians are coming! They are coming in the future to invade the land of Israel. But they won't be alone. They will be joined by a vast Islamic alliance of nations' is a slight reterritorialization of Cold War geopolitics. Now that the new American enemy is the Middle East, both Russia and the 'Islamic alliance' are complicit 'evil'. ${ }^{62}$ It is reasoned that the humiliation of losing the Cold War combined with a struggling economy, according to Hitchcock, that 'Russia is more dangerous than ever before'. ${ }^{63}$ This reterritorialization of the post-Cold War (un)certainty, into a new tangible geopolitical framework, gives credence to popular prophecy that vilified the USSR prior to the end of the Cold War. These reasoning practices reduce the conflict to a geo-economic struggle over oil. This then reduces economics to culture by way of apocalyptic struggles and becomes a self-fulfilling prophecy by providing evidence that the end is near.

The persistence of prophecy belief in light of its changing geopolitical registers is related to the consistent and growing levels of evangelical followers in the United States. This of course dissolves into the question of why evangelicals have remained strong in America. If we understand then that Evangelical churches are a necessary precondition for Christian prophecy, it would be interesting to illuminate why evangelical Christianity is so vital to the American psyche. David Campbell, in his insightful work Writing Security, illustrates how recycled fears of the Other can be powerful tools in keeping a

\footnotetext{
${ }^{62}$ Hitchcock, The Coming Islamic Invasion of Israel, p.41.

${ }^{6.3}$ Hitchcock, After the Empire, p.2.
} 
moral order. ${ }^{64}$ However, fear of Russia for the premillennialist is a form of security and not an inculcation of insecurity. The battle between 'us' and 'them' is bound in dramatic irony: Hitchcock explains that, 'no matter how troubled we are, no matter how dark this world looks, we can know one thing beyond all doubt. We win' ${ }^{65}$ War does not create a climate of anxiety, it takes up the Old World vision of stasis toward a New World future: it is a theatre to be embraced. Embracing the representations of Muslims, Russians, and Europeans as 'malign' both damns the world to perdition and saves the premillennialist from it. But rather than create a climate of anxiety as a means to calcifying followers of a belief system, as Campbell proposes in his formulation of the Puritans, it creates an atmosphere of rapture/Rapture with the same ends by stoking the fire of certainty that the premillennial teleology is the 'true' path of history.

${ }^{64}$ D. Campbell, Writing Security: United States Foreign Policy and the Politics of Identity (Minneapolis: University of Minnesota Press 1998 [Originally published in 1992]) p.32. See also M. Northcott, An Angel Directs the Storm: Apocalyptic Religion and American Empire (London: I.B. Tauris 2004) p.10 and 17-20.

${ }^{65}$ Hitchcock, The Second Coming of Babylon, p. 170. 


\section{Act 3:}

\section{Knowing the Evil Other}

The changing prophetic geopolitics of the world serve as an example of how spatial constructions (in this case strongly tied to the territorial state) have defined regional conglomerations of the Other 'out there'. American foreign policy and colonial discourse were created in sets of metaphoric binary constructions of the Other like 'civilized' and 'barbaric', 'progressive' and 'backward', 'capitalist' and 'communist', 'Christian' and 'Muslim', that find their 'commonsense' understandings in social myths. ${ }^{1}$ This religious binary metaphor razes the complex terrain of these cultural geographies and histories, in this case the Middle East, rendering it culturally and morally flat as Western society is led to believe that culture comes in geo-packages of 'us' and 'them'. The 'evil' Muslims are represented as the threat and the feared unknown; they are what Derek Gregory calls a 'hyper-villain' and what Sophie Bessis calls 'unfathomable otherness' from which a category of a 'good-us' can be derived. ${ }^{2}$ In this same way, post-Cold War prophecy, adopted, informed, and inflamed these binary qualifications of the world, rendering it into divisive geopolitical cells.

The transcendent reversal from God to Hitchcock grants him the blessing of omniscience; one that he gains from a particular reading of the Bible that tells him how

\footnotetext{
${ }^{1}$ On how the experience of American political subjectivity depends on the practice of radical Othering, see M. J. Shapiro, Violent Cartographies: Mapping Cultures of War (Minneapolis: University of Minnesota Press, 1997).

${ }^{2}$ D. Gregory, The Colonial Present: Afghanistan, Palestine, Iraq (Malden, MA: Blackwell, 2004), 161 and S. Bessis, Western Supremacy: Triumph of an Idea?, P. Camiller (trans.) (New York: Zed Books, 2003) p.72 and for the seminal text on the Western construction of the Arab 'Other' see, E. Said, Orientalism (New York: Vintage, 1979).
} 
the actors, acting as homogeneous geopolitical units, will come to reason the destruction of Israel. Like 'Realism' in International Relations which also reduces the world to 'actors' in history and rational 'scenes' in geography, Hitchcock uses a mix of biblical passages with a transposed Western reason for how the Other will act. Once the geopolitics are crystallized, Hitchcock is able to use them and rationalize how the perceived nations and states will play out the final Armageddon. And once transcendent, Hitchcock can remove himself from responsibility for the problems because he is not involved or taking part in them (this idea is taken up further in the last section of this thesis) (See Figure 6 p.65).

This chapter explores how the apocalypse is represented to occur, and to a lesser extent, with what effects. It will also explore the binary geographies of 'good-Christian' and 'bad-Muslim'/'evil-Communist' that help legitimate geopolitical constructions of the world that designates how the Other will act based on state or regional borders. This textual colonization, through geopolitical representation, as knowing the minds of the Other, will be 'dis-orient-ed' not through a liberal reading of the historicity of the Bible, but by debunking the 'power/knowledge/space' triangle presented and justified through theatrical metaphors and biblical toponyms. This chapter should make clear that a strategy to have a single enemy is to shore up a morally distinct American society in antithesis to ideological Islam, thus smoothing away the vast differences across Islamic spaces in making the Other. Upon demonizing the Other, the premillennialists purify themselves by disassociation. 


\section{Othering Strategies: Heaven/Earth, American/Middle East}

Dalby defines geopolitics as a boundary producing practice by excluding the Other and including the Same. Otherness involves exclusion which is inherently spatial. ${ }^{3}$ For Dalby, the practice of critical geopolitics is understood as an investigation of the origin and effects of discursive structures. In other words, how discourses are constructed through discursive practices that are often founded on commonsensical assumptions like 'usgood', 'them-bad'. Hitchcock's geopolitical lines are also making an inside and an outside as a way to see difference as a strategy to create a 'hierarchically ordered whole'. ${ }^{4}$

The world is a blank map to Hitchcock. With the Bible in his right hand and a newspaper in his left, he delineates that world into hemispheres of good and evil. The specious passivity of Muslims to be so represented in the evil-half, is imagined by Hitchcock as a detached observation. Edward Said writes that 'the language [used] to describe Islam was never accurate nor meant to be so as to make alien and incorporate to understand the difference from which Europe [and now the USA] itself was[/is] constructed' ${ }^{5}$ However, the Middle East is not written in Middle Easterners' terms but is rather a reference to Christian and Western conceptions of an already known thing. In Said's terms, these representations have "less to do with the Orient than it does with "our" world' and he continues that 'there is no doubt that imaginative geography and history help the mind to intensify its own sense of itself by dramatizing the distance and difference between what is close to it and what is far away' ${ }^{6}$ It is a power/knowledge

\footnotetext{
${ }^{3}$ S. Dalby, 'Critical Geopolitics: Discourse, Difference, and Dissent', Environment and Planning D: Society and Space 9 (1991) pp.261-283.

${ }_{5}^{4}$ D. Gregory, Geographical Imaginations (Oxford: Blackwell, 2004) p.36.

${ }^{5}$ Said, Orientalism, p.71.

${ }^{6} \mathrm{Ibid}, \mathrm{p} .12$ and p.55.
} 
dynamic that 'represents, animates [and] constitutes the otherwise silent and dangerous space beyond familiar boundaries'. ${ }^{7}$ A self-representation is then replaced with a Christian or biblical one. Inhabitants of the 'Orient' are not only the 'people without history' as Wolf noted, but also the 'people without geography'. ${ }^{8}$ That is, they are not entitled to a position from which to write their own space, it is determined for them, before them, in the Bible but interpreted by Hitchcock. People's relationship to their own land, borders and contingencies is denied.

These dualisms will be referred to as 'Manichean geographies' in reference to the USA because it refers to the Persian 'black' and 'white' distinction just as the Christian 'good' and 'evil' is sequestered. ${ }^{9}$ These Manichean or religious metaphors raze the complex cultural geographies, in this case of the Middle East, rendering it culturally and morally flat. Symptomatic of Hitchcock's resolution to define his discourse as that of God is his ability to define Christians as Godly. The result defines those without a Christian sense of themselves as un-Godly, and in antithesis of Good-that is, of evil. This is not a discourse exclusive to Hitchcock, or even other prophecy writers, but in many ways the Christian underpinnings of a society bent on the Manichean dualism of Good and Evil. As John Walvoord put it, prophecy highlights the 'conflict between good and evil which is the basic Christian philosophy of history'. ${ }^{10}$ When Hitchcock identifies Magog (Kazakhstan, Kirghizia, Uzbekistan, Turkmenistan, Tajikistan, and the Ukraine)

\footnotetext{
${ }^{7}$ Ibid, p.57.

${ }^{8}$ See, E. Wolf, Europe and the People Without History (New York: Columbia University Press, 1982).

${ }^{9}$ Gregory, The Colonial Present, p.48. In literal, white/black terms, LaHaye and Jenkins' in there book Glorious Appearing, describe Jesus as a Caucasian male: 'Jesus was girded about the chest with a golden band. His head and hair were like wool, as white as snow'. T. LaHaye and J. B. Jenkins, Glorious Appearing (Wheaton, Il.: Tyndale, 2004) p. 350.

${ }_{10}$ J. F. Walvoord, The Nations, Israel, and the Church in Prophecy (Grand Rapids, MI: Zondervan Publishing, 1988) p.103.
} 
as 'barbaric savages' he is doing so to shore-up himself, his followers and his country as a 'negative confession' where the real sinners are the enemies.

Of course the blame for this political subjectivity cannot be placed squarely on Hitchcock or premillennialists. It is in many ways a nationalistic, cultural and political act. 'Islam', 'Arab', and the 'Middle East' are all categories that have and are gaining presuppositional understandings in the United States through discursive categorizations of 'what to think' and 'what to do' when one encounters the words (subject) or representation (object) that give 'them' meaning. The very popular children's television show the Care Bears had the 'evil doers' come from Baghdad. Shrieky and Mr. Beastley (the 'evil doers') themselves were unquestionably drawn to look Arab, with dark skin and eyes, dark and thick eyebrows, and their home was a cave on a barren and sandy mountain side. ${ }^{11}$ This in many ways is an apt analogy considering the Christian underpinnings the show displayed: the bears lived in the clouds or Heaven (not unlike Raptured Christians) and those of the Earth were humans in need of Christian Care and protection from Evil, mysterious people from Iraq. This is not ancillary; it is rather crucial to this argument. Even many children in North America are taught uncritically to associate 'bad girls' and 'bad guys' with specific geographies like Baghdad and complexions that resemble Arabs. Certainly this is not limited to the media. These 'commonsensical' categories are also religio-historical notions of place like that of 'Islam'. To designate a place 'Islamic' is to 'designate an implicit foreign policy', a way

\footnotetext{
11 'The Magic Lamp', Care Bears Vol. 4 (2003). In this episode, the Care Bears travel to Baghdad and Grumpy finds a magic Arab lamp qua Disney's Aladdin.
} 
of dealing with the land and the people. ${ }^{12}$ Not just any type of diplomacy is possible because the in-situ history and geography are already determined in the Middle East.

Figure 9
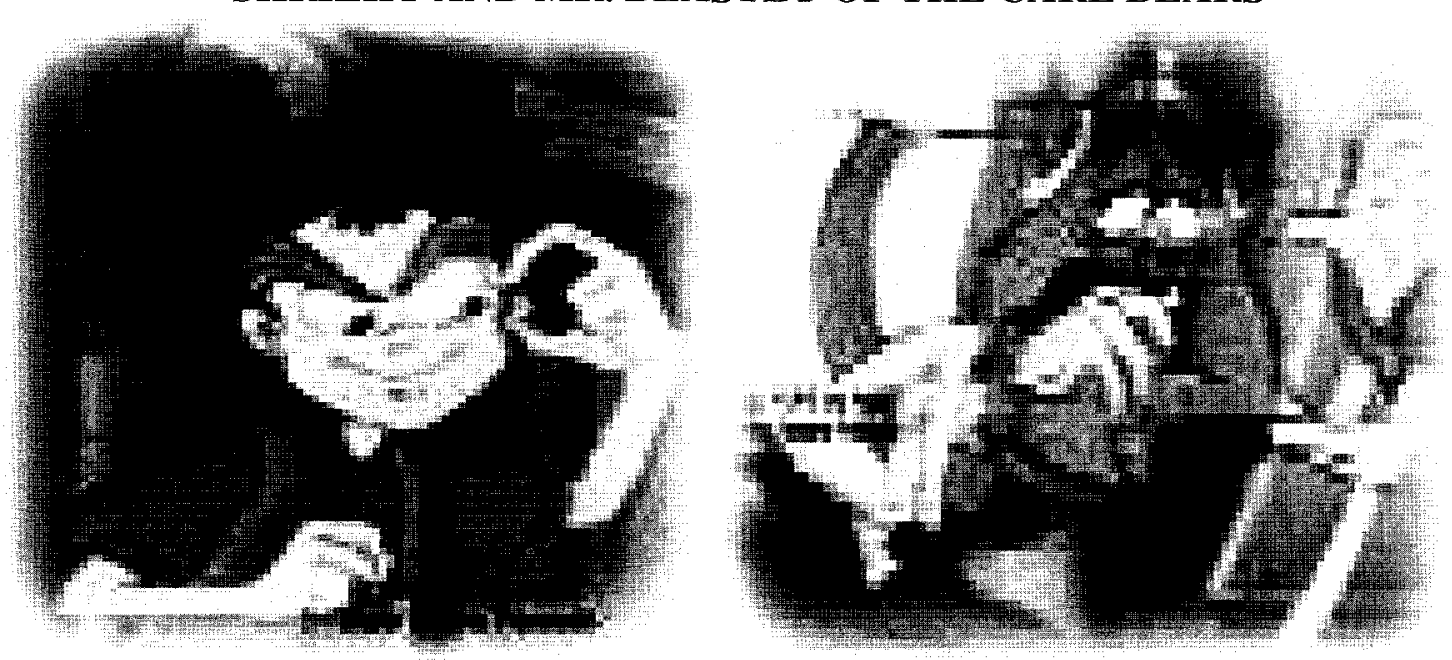

Sources: http://wishbear.net/meet/shrieky.jpg and http://wishbear.net/meet/beastly.jpg.

When Hitchcock verbalizes his Manichaean dualism in reference to the Other we can extract at least two strategic intentions: (1) with definition, he is verbalizing the rationality of the Other's intention to act; and, (2) he is verbalizing the moral quality of the act of the Other. Hitchcock's liturgy is literalizing and verbalizing his geopolitics making it a performative act(ion). What 'they' intend to do to Israel becomes a 'reality' through a discursive practice. The act of communication for Hitchcock is the act of creation; he creates a 'they' and thus a world for 'them'. This is not to discount the historical understandings and meanings attributed to Muslims, in fact this is integral to the argument, as is noted with the Care Bears example above. Pulling from historical meanings and categories attributed to Others certainly transfers into this dualistic structure. However, new sets of meanings are attributed to each under the Christian

${ }^{12}$ G. Ó Tuathail and J. Agnew, 'Geopolitics and Discourse: Practical Geopolitical Reasoning in American Foreign Policy', Political Geography. 11/2 (1992) p.194; See also, Said, Orientalism, p.60-72. 
cosmology divided between 'good' and 'bad'. The distinction, particularly the 'bad', essentializes and qualifies the term as though it were age old knowledge; knowledge understood and conveyed by Hitchcock (the father), to the reader (his daughters and sons). ${ }^{13}$ This assumption and assertion is in no way separate from an intention. The intention, through the verbalization of definitions and representations, creates a 'reality' founded on communicated biblical 'truths'. Certainly this performance of definition does not equate to a performance of war against the Muslim Other but it may justify it (something that will be discussed in the conclusion).

The second intention, that of the justification of enmity requiring a moral meaning, either attributes meaning to the Other or removes it by denying the enemies' morality. Premillennialists represent themselves under the banner of justice and by command of Christianity the enemies are denied that same need. The enemy cannot have the same ethical or moral norm. '[M]oral/grammatical code' of meaning in the world suggests that the Other does not occupy the same 'natural/moral space'. ${ }^{14}$ Certainly the Christian designation of 'bad' or 'evil' has historical resonance. Reagan's 'evil empire' in reference to Communism was a historically constructed ideological maxim; a portmanteau that pulled from the pre-détente Cold War and revived with hyper-moral language. ${ }^{15}$ Hitchcock's 'evil Muslims' recounts a whole world of reference structures that can qualify as a moralized, and premillennial, discourse. Hitchcock's language in many ways qualifies the intended act of Armageddon, in what Mills called 'motives':

\footnotetext{
${ }^{13}$ See G. Lakoff, 'Our Moral Values', The Nation (2004) [http://www.thenation.com/doc.mhtml?i=20041206\&s=lakoff] for this in reference to George W. Bush. ${ }^{14} \mathrm{~J}$. George, 'Understanding International Relations after the Cold War: Probing Beyond the Realist Legacy', in M. J. Shapiro and H. Alker (eds.) Challenging Boundaries: Global Flow, Territorial Identities (Minneapolis: University of Minnesota Press, 1996) p.64.

${ }^{15}$ S. Dalby, Creating the Second Cold War (New York: Guilford 1990).
} 
'Adjectives such as "good", "pleasant", and "bad" promote action and deter it'. ${ }^{16}$ Performances act upon the people, in this case Americans in general and premillennialists in particular, by either informing them or modifying their definitions and thus perceptions.

\section{Othering Between the Border of Heaven and Earth}

For Hitchcock 'morals' are stripped away through the act of calling Muslims 'barbaric savages' but he finds some agency outside of God's hands for Muslims. There is a theological separation from what is 'natural' in terms of God's volition beyond human control and an etiology of what is human-induced. Hitchcock gives Muslims, for example, free agency to be 'evil'. He explains, 'They want to come [destroy Israel]. They 'devise an evil plan'. ${ }^{17}$ Using Acts 17:24-26 as a template for his verse, Hitchcock writes, 'God is the Creator of all things and has determined when they will rise, when they will fall, and where the exact boundaries of their expansion will be' ${ }^{18}$ It is then not suffrage or international relations, but God who appoints our Presidents, Prime Ministers, dictators, and starts war and lays plain for us the geopolitical lines of the planet. Jesus, in many ways is written as an absolute dictator in an absolute Christian world having no tolerance for any other religion or practice that does not fall within His doctrine. Such

\footnotetext{
${ }^{16}$ C. W. Mills, 'Situated Actions and Vocabularies of Motive', in M. J. Shapiro (eds.) Politics and Language (New York: New York University Press, 1984) p.17.

${ }^{17}$ M. Hitchcock, The Coming Islamic Invasion of Israel (Sisters, OR: Multnomah, 2002) p.23. Hitchcock is making reference to Ezekiel 38:10: 'Thus says the Lord God, "It will come about on that day, that thoughts will come into your mind, and you will devise an evil plan"' referenced from the NAS. Also note that Hitchcock cites between four Bible translations for the most germane scripture quotations as a strategy to support his geopolitics: KJV, NAS, The Holy Bible, New Living Translation (NLT) (Wheaton, Ill: Tyndale, 1996), and The Holy Bible, New International Version (NIV) (Grand Rapids, MI, Zondervan, 1984).

${ }^{18}$ Hitcheock, Is America in Bible Prophecy? (Sisters, OR: Multnomah, 2002) p.16. Acts 17: 24-26 reads: ' $\mathrm{He}$ is the God who made the world and everything in it.... He himself gives life and breath to everything, and he satisfies every need there is. From one man he created all the nations throughout the whole Earth. He decided beforehand which should rise and fall, and he determined their boundaries'. NLT.
} 
scorn 'turns a blind eye' to enmity and war snowballing its way to self-fulfilling prophecy. Therefore, Hitchcock has naturalized Muslims as wanting to be evil but they will act in the battle of Armageddon as God has directed.

Premillennialists are also given some agency before the Rapture, that of the ability to accept Jesus Christ as their true savior. The final chapters in most of Hitchcock's books have titles such as: 'Are you rapture ready?' or 'Ready to ride?' or 'Ready or not?'. These chapters provide all the security from perdition one needs. Hitchcock asks, '[w]hat must I do to be saved?' then answers his question listing three obligatory preparatory acts for a secure future with God: (1) Admit: 'You must realize that you need to be saved', citing Romans (3:23) that 'For all have sinned and fall short of the glory of God'; (2) Acknowledge: 'You must acknowledge that you need a Savior.' Here Hitchcock asserts that humans cannot save themselves or other people, citing Ephesians (2:8-9) for evidence: 'For by grace you have been saved through faith; and that not of yourselves, it is the gift of God; not as a result of works, so that no one may boast;' and (3) Accept: 'You must receive or accept Jesus Christ as your personal Savior from $\sin ^{, 19}$ In other words, people must believe in Jesus to become 'children of God' (John 1:12). With these three easy steps God will 'deliver us/U.S. from evil'.

The Muslim is an 'outsider', a threat to human kind while the premillennialist is the 'insider,' the one with the knowledge to break free of the shackles of global tragedy by using the understanding of God's succour. The Middle East for example, is the equivalent to an inverted purgatory; it is the antipode of the United States. This is a very political move, one that excludes 'us' from 'them', 'inside' from 'outside' through the border between Heaven and Earth. To be excluded from the premillennial discourse is

\footnotetext{
${ }^{19}$ M. Hitchcock, What on Earth is Going On? (Sisters, OR: Multnomah, 2002) pp. 105-07
} 
essentially to be denied the potential for everlasting life and thus any evidence challenging this belief in history is challenging the security provided by the discourse. Representing Muslims as threat and security both damns the world to perdition and saves the premillennist from it. In terms of security beyond that by faith, is a security of the disciple of premillennial dispensationalism. It is, of course, an imagined discourse influenced since its inception by non-discursive practices like American politics that in many ways serves as the pillar to its very existence. If there were no strife or wars, Cold or otherwise, premillennialism would have no Heaven to stand on.

\section{Othering Between America and the Middle East}

There is a nationalistic and 'Practical geopolitics' to all this notwithstanding the postnation-state omnipotence and judgment God will bring. Diametric difference on a world scale that separates Christians from Muslims serves as a new template for the division between East and West, where the former and antipodal opposite makes the latter possible as a negative-portrait of the 'self' being grafted onto the Other to make sense of 'them'. ${ }^{20}$ As Burke states in relation to the mobalization of nationalism in World War II Germany, 'if a movement must have its Rome [its Jerusalem], it must also have its devil [its Babylon]'. 21 Showing that 'Middle Eastern Muslims' or 'European hedonists' are 'evil' is a political move in relation to the United States, one that excludes 'inside' from 'outside' through the borders between America and the Middle East. ${ }^{22}$ Representing the

\footnotetext{
${ }^{20}$ J. Agnew, Geopolitics: Re-visioning World Politics (London: Routledge 1998) pp.20-21.

${ }^{21}$ K. Burke, 'The Rhetoric of Hitler's "Battle", in M. J. Shapiro (eds.) Politics and Language (New York: New York University Press, 1984) p. 60.

${ }^{22}$ For a discussion on the spatial separation between Heaven and Earth, see L. Thompson, "Mapping the Apocalyptic World', in J. Scott and P. Simpson-Housley (eds.), Sacred Places and Profane Spaces: Essays in the Geographics of Judaism, Christianity, and Islam (New York: Greenwood Press, 1991) pp. 115-130.
} 
world in these simple categories has powerful effects in mobilizing public opinion, makes that boundary impermeable, and erodes the possibility for other ways of knowing.

Hitchcock's geopolitical epithets of the Other are 'trapped' into state boundaries notwithstanding the post-nation-state omnipotence and judgment Christ will bring. ${ }^{23}$ Premillennialism exists almost exclusively in the United States. One figure Hitchcock suggests is as high as 65 million Americans to be Raptured before the Tribulation. ${ }^{24}$ America, he concludes, 'would lose the very best, the salt and light of this great land'.25 The Muslim or European is an 'outsider', a threat to the premillennialist 'insider'. The insider has the knowledge to break free of the shackles of global tragedy using the understanding of God's plan.

Hitchcock opens his book Is America in Bible Prophecy? as follows: 'I love Bible Prophecy and I love America' ${ }^{26}$ Because of Hitchcock's 'Ameraphilia' he still sees his country as Divine and blessed by God. Hitchcock, using nationalism as set in a Puritan ideal of a Divine land, writes, 'God has blessed America because it provided the ideal soil for His Word to take root and flourish', and further, 'God has blessed America because of America's friendship with the Jewish people and the state of Israel'. ${ }^{27}$ In foreboding language, Hitchcock explains that because America will "not figure largely in either the political, economic, or religious aspects of the world' during the Tribulation, America

\footnotetext{
${ }^{23}$ See J. Agnew, 'The Territorial Trap: The Geographical Assumptions of International Relations Theory', Review of International Political Economy 1/1 (1994) pp.53-80.

${ }^{24}$ Hitchcock, The Second Coming of Babylon (Sisters, Ore.: Multnomah Publishers 2003) p.155. Hitchcock justifies America as a Holy and privileged place in the world by citing statistics that 23 percent of Americans are evangelical; while only 0.3 percent of the Middle East, 11.4 percent of Africa, 2 percent of Europe and 9.1 percent of Latin America, are evangelical. Hitchcock, Is America in Bible Prophecy?, p.69 and 88.

${ }^{25}$ Hitchcock, The Second Coming of Babylon, p.155. 'Salt and light' is making reference to Matthew 5:1314: 'Ye are the salt of the earth: but if the salt have lost his savour, wherewith shall it be salted? it is thenceforth good for nothing, but to be cast out, and to be trodden under foot of men'. 14: 'Ye are the light of the world. A city that is set on an hill cannot be hid'. KJV.

${ }^{26}$ Hitchcock, Is America in Bible Prophecy?, p.7.

${ }^{27}$ Ibid, p. 141.
} 
may 'suffer a fall from the outside', that is, America will be destroyed by 'Other' nations from 'out there'. He maintains, however, that it may be the 'Outside' Muslims that finishes off vulnerable America, as 'The Rapture will render America a second rate nation' leaving behind only those non-Christian Americans to run his/His great country. As an example of this privileging of America, much of Hitchcock's work on the 'evil' making of Muslims is based on the terrorist attacks on September $11^{\text {th, }}, 2001$. However, despite living in Oklahoma, he does not problematize the 1995 terrorist attack on the Murrah Federal Building. There was nothing in the Bible or in American nationalism for him to explain why a fellow American would do such a thing. The us/them construction diverts attention from 'us' on the inside-the 'go(o)d'- to focus on 'them'-the 'evil'. ${ }^{28}$ Hitchcock's focus on America is creating an Island of truth and faith where everything around it is not.

Through premillennial interpretations, the Bible becomes an Orientalist text. It is a text that claims to know 'who and where Muslims are' and more importantly 'how they will act'. To Hitchcock, Muslims have been the 'evil' that occupied the Holy lands of Israel. The dangers of the past, whether the Soviet Union or Islam, are the dangers of the future, thus legitimizing a timeless geopolitical organization. Sidaway argues, however, that the animosity between Christianity and Islam when seen as a historical 'revival' is misleading. Sidaway continues that such historical events are said to have sharpened the difference between Christians and Muslims. For example, the Crusades were more about

\footnotetext{
${ }^{28}$ Ibid, p.63. On 9-11, see Hitchcock, What on Earth is Going On?, pp.17-22. See M. Sparke, 'Outsides Inside Patriotism: The Oklahoma Bombing and the Displacement of Heartland Geopolitics', in G. Ó Tuathail and S. Dalby (eds.), Rethinking Geopolitics (London: Routledge 1998) pp.198-223. Other premillennial writers found America's doom in Isaiah 18:1-2, translating that 'meted out and trodden down' in the verse meant that USGS and other comprehensive geographic surveys done in America were a reference to the United States, see J. V. Impe, 11:59 and Counting (Nashville, TN: T. Nelson, 1987) p. 187.
} 
'alliance and cooperation' between Christian sects than war against Muslims. ${ }^{29}$ Similarly Bessis, in her alternative histories of the relationship between Islam and Christianity, writes that Islam 'sank lasting roots in the far West of Europe'. ${ }^{30}$ Prior to the eleventh century, Christianity and Islam were a cultural melting-pot particularly in Mediterranean Europe. At this time 'Christian thought then identified the Arabs with men of reason' ${ }^{31}$ It would then take a realization of 'self' through the construction of an 'Other' for a new Christian ideology to come to fruition as for itself rather than in itself. A self-awareness and consciousness was the construction of a Muslim enemy. ${ }^{32}$ Because Muslims had reason they could be reasoned with and thus understood. However, Apocalyptic views did fuel the Crusades between 1097 and 1270. The Mystic Joachim of Fiore saw Saladin as the Antichrist and saw Jews and Muslims as demons following the Antichrist. ${ }^{33}$ This mission to efface understanding made Muslims 'outsiders whose...customs I do not understand, so foreign that in extreme instances I am reluctant to admit they belong to the same species as my own'. ${ }^{34}$ However, the justifications for the expulsion of Muslims from southern Europe and the Near East became a mission of mastering new lands. ${ }^{35}$ The justification for war remained under the banner of religious separation and a European understanding of (re)conquest, territorial expansion and exploration. In short, Western Europe could only be created through territorial conquest and a politicized Othering of

\footnotetext{
${ }^{29}$ J. D. Sidaway, 'Geopolitics, Geography, and “Terrorism” in the Middle East', Environment and Planning D: Society and Space 12/3 (1994) p.360.

${ }^{30}$ Bessis, Triumph of an Idea?p. 12.

${ }^{31}$ Ibid, p. 14.

${ }^{32}$ M. Mamdani, Good Muslim, Bad Muslim: America, the Cold War and the Roots of Terror (New York: Pantheon Books 2004) p.25.

${ }^{33}$ P. Boyer, When Time Shall Be No More: Prophecy Belief in Modern American Culture (Cambridge, Mass: Harvard University Press 1992) p.51.

${ }^{34} \mathrm{~T}$. Todorov, The Conquest of America: The Question of the Other. R. Howard (trans.). (New York:

Harper \& Row, 1984) p.3.

${ }^{35}$ Bessie, Triumph of an Idea?, p. 14.
} 
Islam. Although in part a historical separation, ${ }^{36}$ it is a recent geopolitical strategy to provide an alien Other, consequently justifying a 'barricaded [American] state'; ${ }^{37}$ for both the state and premillennialism the association of Muslims as terrorists conditions belief.

But how, if Muslims are so alien, can Hitchcock know how they will bring about Armageddon? Premillennial perceptions of Islam grow from purely Christian constructions. The Other is an expression of the 'Self'; 'we' construct 'them' from 'our' knowledge, perceptions and ways of knowing. ${ }^{38}$ Both the 'Middle East and Muslims' or 'Europeans and hedonist religion' are 'singular prisons of meanings' that are about making other peoples' histories by way of making 'ours' ${ }^{39}$ Edward Said writes that such geopolitical categories 'allow one to see new things, things seen for the first time, as versions of a previously known thing. ${ }^{40}$ It is this ability to be able to 'unveil' and read the mind of the Other that gives credence to the ability to map 'the Muslim mind' ${ }^{41}$ 'For Muslims', Hitchcock explains in relation to Christianity, 'there is no middle ground. One is either a true believer or an infidel, saved or damned, a friend or an enemy of God, a member of God's army or a follower of Satan'. ${ }^{42}$ But these are not seen as polar opposites; premillennialists distinguish themselves in this manner. The premillennialist

\footnotetext{
${ }^{36}$ E. Said, Orientalism, p.87. For scholarship on this Christian/Muslim division stemming from the Crusades, see also, A. Osiander, 'Religion and Politics in Western Civilization: The Ancient World as Matrix and Mirror of the Modern', Millennium: Journal of International Studies 29/3 (2000) pp.761-790.

${ }^{37}$ M. Coleman, 'The Naming of 'Terrorism' and Evil 'Outlaws': Geopolitical Placemaking After 11 September', Geopolitics 8/3 (2003) pp.91-93.

${ }^{38}$ D. Campbell, 'Political Prosaics, Transversal Politics, and the Anarchical World', in M. J. Shapiro and H. Alker (eds.), Challenging Boundaries: Global Flow, Territorial Identities (Minneapolis: University of Minnesota Press 1996) pp.21-22.

${ }^{39}$ D. Gregory, The Colonial Present: Afghanistan, Palestine, Iraq (Malden, MA: Blackwell 2004) p.18.

${ }^{40}$ Said, Orientalism, p.63 quoted in Gregory Ibid.

${ }^{41}$ I do not claim, however, that there is a 'real' or correct representation of 'Muslims'. I am instead focusing on how geography has been made to see Muslims as 'evil'. The cover epigraph on Charles Dyer's major work, for example, reads: 'Inside the mind of the Iraqi dictator: How new satellite images reveal what's really behind this Mideast menace'. See pp.97-104 for satellite photos. For a popular Orientalist text that claims to 'know the Arab' with consistency, see R. Patai, The Arab Mind Revised Edition (New York: Hatherleigh Press 2002) pp.12-24.

${ }^{42}$ Hitchcock, The Silver Kingdom, p.23.
} 
has grafted diametric oppositions onto the 'Muslim' by contrasting 'them' from the knowledge of 'us' with the result of 'produc[ing] the effects that it names'. ${ }^{43}$

Because the Bible is relatively silent as to why Muslims will destroy Israel, Hitchcock takes it upon himself to make Bible prophecy believable in contemporary political understandings of the world. He delves into the 'Muslim mind' and outlines three reasons for the invasion: first, 'Death to Israel: Islam will be motivated by a Satanic hatred for the Jewish people to completely cover their land and wipe them off the face of the earth'; second, 'Plunder!: to capture spoil and seize plunder...these nations will come out of greed, envy, and jealousy...not only to eradicate Israel, but [also] to enrich themselves at her expense'; and third, 'Down With the West': to antagonize the West into going to war. God can only foretell 'the future of Islam', ${ }^{44}$ however, Muslims 'want to come. They "devise an evil plan", and God holds them responsible for it'. ${ }^{45}$ This strategy of 'knowing the Other' is not of Hitchcock's own making and is rather a pedigree made most popular by Hal Lindsey.

Lindsey, among others, used classical geopolitical and geoeconomic reasoning to justify to readers why Russia would come to destroy Israel. From natural resources like oil and minerals from the Dead Sea to warm-water ports, Lindsey's ability to translate the Bible into Realist reasoning became one of the major reasons for his unprecedented appeal and success. Though many books had been written on the relationship between regional geography and prophecy, Lindsey was among the first to suggest that regional alliances were signs for Christ's predicted return. ${ }^{46}$ Lindsey's maps (See Figure 7 p.74)

\footnotetext{
${ }^{43}$ Gregory, The Colonial Present, p. 18.

${ }^{44}$ Hitchcock, The Coming Islamic Invasion of Israel, pp.77-78 and 10.

${ }^{45}$ Ibid, p.23.

${ }^{46}$ Boyer, When Tomorrow Shall Be No More, pp.5-7.
} 
show his ability to interpret the Bible in modern terms in an easily graspable geopolitics of truth. Further, Lindsey used such 'plausible' explanations to reason through Russia's prophesized invasion of Israel. Perhaps the most blatant example of 'knowing the Other' is found on the cover epigraph on Charles Dyer's major work. It reads: 'Inside the mind of the Iraqi dictator: How new satellite images reveal what's really behind this Mideast menace' (See Figure 10). Dyer's use of twelve satellite photos of Babylon combines the truth of geography with the ability to know the real reason Saddam Hussein is rebuilding Babylon. $^{47}$

Figure 10

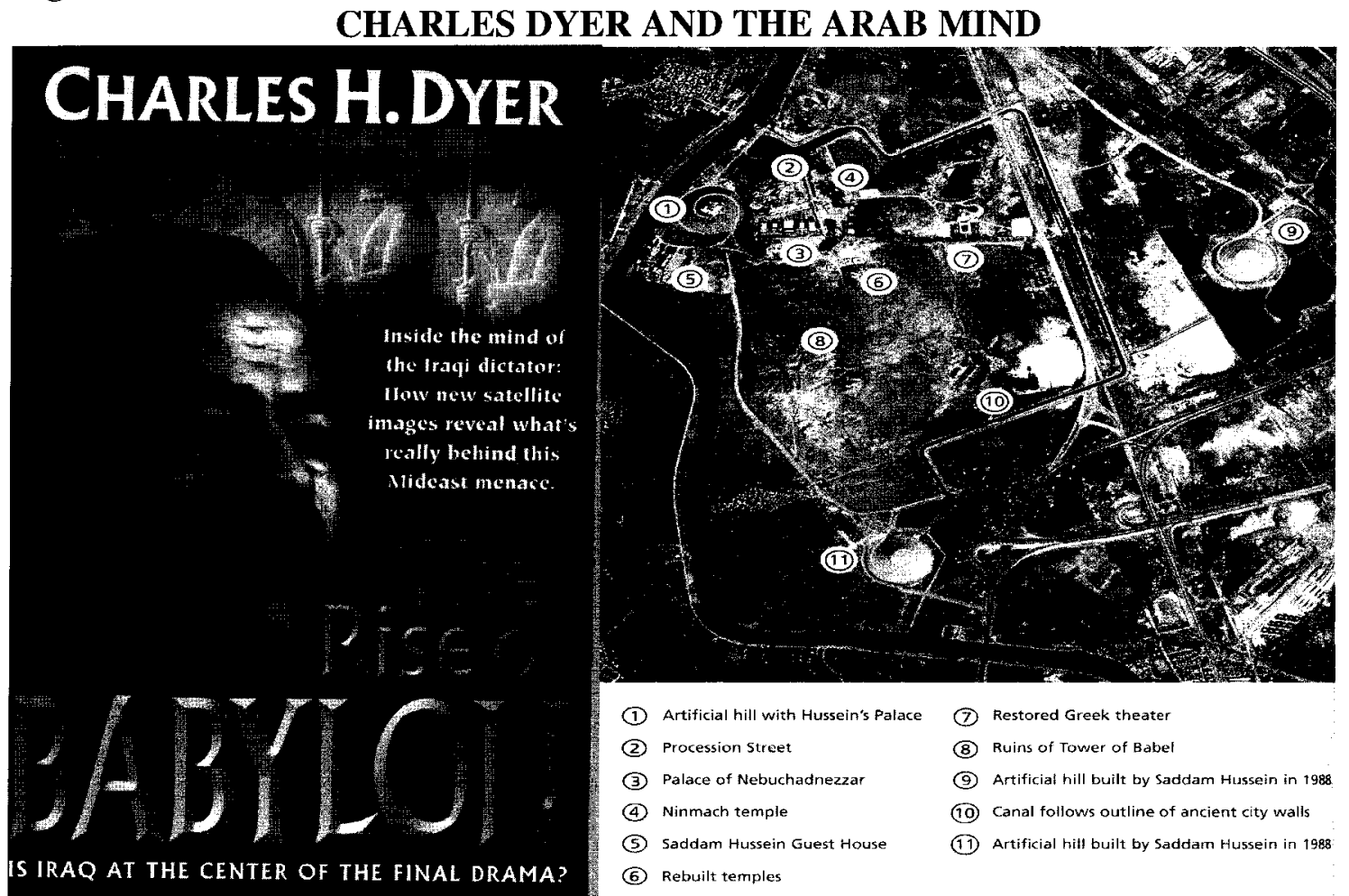

Note the Epigraph on the Cover and the Subtitle. The map is a plate in the book without page numbers.

${ }^{47}$ See Dyer, The Rise of Babylon, pp.97-104 for satellite photos. 
The act of 'knowing the evil Other' through biblically inspired geographical representations is an active process of performitivity; tautologically engrained through history, through church and sermons, through texts and the media and politicians, all of which make premillennial doctrine possible. Hitchcock's geopolitical category of a seamless Middle East denies cultural and religious syncreticism and is so restrictive that, for example, he is unable to see a division between Shiite and Sunni Muslims. Hitchcock does not account for colonialism's role in creating regional animosity. To Hitchcock, all Muslims are 'evil', encased in a simple and foreordained premillennial geography. Reconciliation or common ground with Muslims is not possible with Hitchcock's maps. That these are 'evil' people who do not comprehend reason is combined with his ideology of the future of the world and the future of his religion. Hitchcock's hopes to institutionalize his premillennial geopolitical imagination 'to warn unbelievers of the wrath to come and encourage believers to live in view of the soon coming of our Savior' will not be easily abjured and deterritorialized. Premillennialism is a process of infinite becoming played out as a finite certitude. ${ }^{48}$ For as sure as there will be battle lines drawn 'out there' there will be premillennialism.

\footnotetext{
${ }^{48}$ Hitchcock, The Silver Kingdom, p.2.
} 


\section{Curtain}

In the section that follows, the influence that premillennial texts (like Hitchcock's) and lobby groups have on foreign policy, government and the environment will be explored. This section will tie US President George W. Bush's political performances to the premillennial sphere of influence. The second section will outline how this thesis has contributed to the 'critical geopolitics' literature, how 'theatre as theory' can be used in secular and religious geopolitical analysis. Furthermore, it will outline further research possibilities for both 'religion as geopolitics' and for premillennialism. This section will also look at ways to see the world beyond 'insides' and 'outsides' of 'good' and 'evil', how Christianity has been mobilized to justify war and conversely, how Christianity in general can and has been mobilized as a tactic toward peace and cross-cultural acceptance.

\section{Merging Political and Premillennial Sight}

The importance of this thesis should be clear when we remember that academics and political elites are not separate from culture-religion included. ${ }^{1}$ They are influenced by their beliefs and their beliefs may have a profound impact on politics. However, this raises the question: How might one who accepts premillennialism deal with the present age when all hope is focused on Christ's second coming? As was written in the

\footnotetext{
' J. Sharp, 'Re-maculinizing Geopolitics? Comments on Gearóid Ó Tuathail's Critical Geopolitics', Political Geography 19/3 (2000) p.362.
} 
introduction, premillennialism has a strong sense of historical determinism, however this does not stop premillennialists from having both covert and overt political agendas; they are not solipsistic.

As was made clear in chapters 4 and 5, the geopolitics of the United States becomes the geopolitics of premillennial prophecy. But how has premillennialism influenced those American geopolitics? And how has the American government used premillennialism and Christian discourse to justify their geopolitics? George W. Bush's hyper-(im)moral and religious performances speak to the Christian and premillennialist electorate. Bush's religious language is derived from premillennialist discourse just as premillennial language is reinforced by Bush's argot religious performances. Sparke's term the 'Jesustrick' which he defines as: 'imagined in the geo-politically incarnate form of the U.S. military coming down to earth (or at least dropping bombs down to earth) and bringing neoliberal apostates and agnostics into order', ${ }^{2}$ is of interest here in how Bush and his administration, like Hitchcock and his congregation, have transcended the theatrum mundi to judge it. Bush does this in terms of a moral criterion of reform concomitant with his position of authority. Bush's performances justify how the decisions made in the war have been the 'correct' ones. It is a process of legitimation through ideological representation where ideology is a discursive practice that 'conceals relations of power, presents them as legitimate, or acts to reify or naturalize them by portraying a transitory historical situation as eternal and hence natural'. ${ }^{3}$ As Strong eloquently points out, 'words do not mean what one wants them to mean, they mean what the speakers need to have

\footnotetext{
${ }^{2}$ M. Sparke, In the Space of Theory: Postfoundational Geographies of the Nation-State (Minneapolis: University of Minnesota Press, 2005) p. 308.

${ }^{3}$ S. Dalby, Creating the Second Cold War (New York: Guilford 1990) p.9.
} 
them mean if their position and integrity is to be preserved'. The performance of language is, then, the act of making things the same for people in auditorium America-a place physically removed from the still visible wars that such performances legitimate.

Bush and his administration certainly use apocalyptic fever to justify foreign policy. His labelling of enemies as 'evil doers', wars of 'liberation' as 'crusades', and his future that features 'God's return', make it seem that Bush is playing some prophetic role for the End Times most notably through the War in/on Iraq. The theatre of Iraq is, in Northcott's terms, 'interpreted by dispensationalists as an end time event, because Revelation 9: 1415 speaks of the release of "four angels which are bound in the great river Euphrates" who will destroy one-third of men on the earth'. ${ }^{5}$ Northcott's book An Angel Directs the Storm, a phrase Bush made in reference to himself in his first Inaugural Address, makes this point clearly. Bush's call for a 'Crusade' on September $16^{\text {th }} 2001$ should come under some kind of deconstructive pen. ${ }^{6}$ Historically the Crusades are, of course, the territorial Christian wars bent on capturing the 'Holy lands' occupied by Muslims. A crusade can, however, come to mean any war in the name of a religion. The fact that Bush would refer to the 'War on Terror' as a religiously motivated war on two notable occasions is certainly suggestive of a socio-historical presupposition. Bush's 'Crusade' remark speaks to people whether they are Christian or not. The mission is set: dictatorships will be converted to democracies; 'insurgents' will be punished; 'bad' Muslims will be made 'good' or die. In Bush's 'axis of evil' speech that followed 9-11, he said, in apocalyptic terms:

\footnotetext{
${ }^{4}$ T. B. Strong, 'Language and Nihilism', p.91.

${ }^{5}$ M. Northcott, An Angel Directs the Storm: Apocalyptic Religion and American Empire (London: I.B. Tauris 2004) p.67

${ }^{6}$ Ibid, p. 6.
} 
We've come to know truths we will never question: evil is real, and it must be opposed. Beyond all differences of race or creed, we are one country, mourning together and facing danger together. Deep in the American character, there is honor, and it is stronger than cynicism. And many have discovered again that even in tragedy-especially in tragedy-God is near. ${ }^{7}$

In using this language Bush taps into the core of the premillenial doctrine-an affirmation to premillennialists that he is doing God's work.

Shapiro has argued that the organization of space enmeshed with territorial sovereignty is a moral geography. ${ }^{8}$ Justification and legitimation are contingent on the states' ability to dictate morals or uphold them. It is a performance of making 'normal'. Shapiro again writes that ' $[w]$ hat is normal is morally correct'. The Bush administration's war mongering must on some level be 'normalized' to the public. And more than enmity of the Other or even the internecine effects the administration might have domestically, the making of an 'us', attendant with the privileges associated to inclusion, and defending that constructed quality from 'them', is the 'modus of moral meaning-making' ${ }^{10}$ As LaHaye made clear and anticipates Bush's phrase 'with us or against us', 'It is helpful to keep in mind that there are two kinds of people on the earth: Christians, and unbelievers'. ${ }^{11}$ The Christian concept of 'cultural superiority' and 'moral certainty' used by Bush emboldens 'geopolitical imaginations' that act as natural foundations for 'obligatory' foreign policy thus juxtaposing the iconoclastic 'barbarian'

\footnotetext{
${ }^{7}$ Ibid, p.7.

${ }^{8}$ In S. Dalby and G. Ó Tuathail, 'The Critical Geopolitics Constellation: Problematzing Fusions of Geographical Knowledge and Power', Political Geography. 15/6-7 (1996) p.452.

${ }^{9}$ M. J. Shapiro, 'Introduction', in M. J. Shapiro and H. Alker (eds.) Challenging Boundaries: Global Flow, Territorial Identities (Minneapolis: University of Minnesota Press, 1996) p.5.

${ }^{10} \mathrm{~J}$. George, 'Understanding International Relations after the Cold War: Probing Beyond the Realist Legacy', in M. J. Shapiro and H. Alker (eds.) Challenging Boundaries: Global Flow, Territorial Identities (Minneapolis: University of Minnesota Press, 1996) p.66.

${ }^{11}$ T. LaHaye, The Beginning of the End (Wheaton, IL: Tyndale, 1972) p.25.
} 
enemy to the helpless 'victims' who will be saved by America: 'World Police'. ${ }^{12}$ When the mission is posed in religious simplifications of 'manifest destiny' by Bush, a President with the ethnographic power described by Ó Tuathail and Agnew as the 'shaman and the storyteller [and the pontiff]', the administration can justify military action as morally sound. ${ }^{13}$

Both Senate Environment and Public Works Committee Chair James Inhofe (ROkla.) and former House Majority Leader Tom Delay participate in premillennial circles. Inhofe was once quoted as saying, 'I trust God with my legislative goals and the issues that are important to my constituents', and continued, 'I don't believe there is a single issue we deal with in government that hasn't been dealt with in the Scriptures'. ${ }^{14}$ After a sermon by popular premillennial televangelist John Hagee in which he said, 'The war between America and Iraq is the gateway to the Apocalypse', Delay is quoted as saying, 'Ladies and gentlemen, what has been spoken here tonight is the truth from God'. ${ }^{15}$ Such belief is a vehicle to self-fulfilling, and possibly, self-destructive prophecies.

David Hopewell captures an interesting harangue from premillennial televangelist John Hagee. Hopewell describes a 1993 sermon where Hagee takes issue with a newspaper clipping of the 1992 Earth Summit in Rio de Janeiro depicting 'egregious' environmentalists sitting in a circle; a scene that did not escape Hagee's keen eye for the 'signs'. Hagee preaches, 'I recognized the significance of the magic circle used in satanic

\footnotetext{
12 'World Police' is in reference to the satire movie, Team America: World Police (Paramount Pictures, 2004).

${ }^{13}$ G. Ó Tuathail and J. Agnew, 'Geopolitics and Discourse: Practical Geopolitical Reasoning in American Foreign Policy', Political Geography. 11/2 (1992) p.196.

${ }^{14}$ G. Scherer, 'The Godly Must be Crazy: Christian-Right Views Are Swaying Politicians and Threatening the Environment', Grist Magazine (Oct. 2004) [http://www.grist.org/news/maindish/2004/10/27/schererchristian/].

${ }^{15}$ Ibid. See also, L. Dubose and J. Reid, The Hammer: Tom Delay, God, Money, and the Rise of the Republican (New York: PublicAffairs 2004) pp.226-43.
} 
and occult worship'. ${ }^{16}$ However, Hagee isn't completely unsympathetic to the environmentalist's mission, he too wants clean air and water, but he goes on to say that we should not be fooled, the environmentalist movement simply employs these strategies to establish global dominance: 'the environmental movement is not about conservation. It's about creating an environmental juggernaut that marries the New World Order crowd and the New Age occultists with the objective of bringing about a global crisis that can be solved by a one-world government'. ${ }^{17}$ Hagee continues his admonition, '[t]hose who went to Rio opened themselves, willingly or unwillingly, to the invasion of demon spirits'. ${ }^{18}$ Satan's secret plan has then been debunked in the Bible and the only question concerning the environment has already been answered in the Bible as part of the End Time events. In Hollywood like imagination, Hagee reveals that, 'The earth's atmosphere will be destroyed in a nuclear explosion. That will be the end of the environmental issue. And there's not one thing you can do about it'. The 'pagan cretins', as Hagee terms environmentalists, will finally be exterminated. ${ }^{19}$

Hagee believes that environmental issues are pushing the planet closer to world government. And that those environmental activists are the marionettes of the Antichrist. Hitchcock suggests that '[t]he effects of globalism are everywhere, Just think about it. The Kyoto Protocol that was adopted on December 11, 1997 is an attempt to regulate

\footnotetext{
${ }^{16}$ D. Hopewell, Christian Fundamentalism: A Journey into the Heart of Darkness (Parsippany, NJ: American Atheist Press, 1998) p.66.

${ }^{17}$ Ibid. The atavistic view of global governance as oppressive and foreordained in the Bible is not a new one. The UN, and particularly the EU, have been under incredulous eyes where thought of as the work of the Antichrist attempting to solidify the world by convincing the global community that he brings world peace. See, M. Hitchcock, 'Alignment of the Nations: The Nations of Prophecy are in the News, but How do they Align with Scripture?', Interpreting the Signs. January 15 (2003); M. Hitchcock, 'President of Europe: An Update on the Movement Toward Political and Economic Union in Europe', Interpreting the Signs. January 29 (2003); M. Hitchcock, 'Europe Appeasement, Antisemitism and the Move Toward Unification', Interpreting the Signs. January 7 (2004).

${ }^{18}$ Hopewell, Christian Fundamentalism, 66.

${ }^{19}$ Ibid, p.67.
} 
world environmental conditions'. ${ }^{20}$ Hitchcock portends that 'the entire environment of the planet will be destroyed' after the Rapture and into the seven-year tribulation. ${ }^{21}$ Hitchcock continues in homily that the Book of Revelation 'graphically pictures the worldwide devastation':

The cities of the nations fell... And every island fled away, and the mountains were not found. And huge hailstones, about one-hundred pounds each, came down from heaven upon men (Revelation 16: 19-21). ${ }^{22}$

The Moral Majority, headed by some of the most prolific premillennial writers like Tim LaHaye and Jerry B. Jenkins and of which Hitchcock is a member, believe global warming to be a farce or at least suspect when it is directly at odds with the Republican Party, the Bible, capitalism and myriad of right wing Christian think tanks like, 'The Oregon Institute of Science and Medicine', 'The Trinity Foundation', the 'Acton Institute', and evangelical policy papers like 'The Cornwall Declaration on Environmental Stewardship', all of which find environmentalism or environmental issues suspect because they effectively decenter humans and/or that in some way environmentalism threatens to find common ground between Jews, Muslims, and Christians. $^{23}$

It is not only theologians and Christian organizations that profess and evangelize the premillennial cause. In his book The Carbon War (2001), Greenpeace activist Jeremy Leggett writes of an encounter with Ford Motor Company executive John Schiller during the Kyoto climate change negotiations. Leggett aptly asked how opponents to Kyoto

\footnotetext{
${ }^{20}$ M. Hitchcock, Seven Signs of the End Times (Sisters, OR: Multnomah, 2002) p.72 emphasis added.

${ }^{21}$ M. Hitchcock, What on Earth is Going On? (Sisters, OR: Multnomah, 2002) p.29. Hitchcock, however, does see himself as an environmental steward. On the other hand, he went on to say that 'it seems clear to me that these disasters [from global warming] in the end times will be direct judgments from God and not the result of man's negligence'. Email correspondence with Hitchcock on March $13^{\text {th }}, 2006$. ${ }^{22}$ Ibid, p. 30 .

${ }^{23}$ J. W. Robbins, 'The Sin of Signing Ecumenical Declarations', The Trinity Foundation. (2000) [http://www.trinityfoundation.org/journal.php?id=130].
} 
could deny the impacts of burning fossil fuels. Schiller responded that the scientists had it all wrong when they say that fossil fuels have been sequestered underground for eons because the earth, he states, is just 10,000 , not 4.5 billion years old. Schiller continued, confidently declaring, 'You know, the more I look, the more it is just as it says in the Bible'. ${ }^{24}$ And he concludes that the destruction of the environment will mark the End Time' and return of Christ. ${ }^{25}$

The genres, that of the secular apocalyptic and the premillennial, do differ quite sharply, however. While the secular doomsayers write to change the world through concerted action, premillennialists suggest that nothing can prevent this catastrophic fate. Concern for the future of our planet is irrelevant because this world has no future. Though premillennial fin de siecle scenarios incorporate environmental components which are often linked to the secular concerns and scientific evidence, there remains an impassable boundary between the work of humans and that of God. Only God can renew the earth to its state before the fall from the Garden of Eden. Premillennialists can therefore believe that humans should make no concerted effort to environmental betterment because they do not see their existence with the environment inseparably entangled together as DNA coils: improvement of the present may deprive the world of 'signs' and so act to postpone the end of the age.

Mike Davis (1999) in his aptly titled book Ecology of Fear captures the theme above using the media and the discordant voices of Angelinos over the seemingly 'malign' and 'evil' environment in which they live by asking, 'whether this vicious circle

\footnotetext{
${ }^{24}$ J. Leggett, The Carbon War: Global Warming and the End of the Oil Era (New York: Routledge, 2001) p. 174 .
} 
of disaster [in Los Angeles] is coincidental or eschatological[?] ${ }^{26}$ The answer is of course neither. The geography of Los Angeles is not problematized. Few consider the fault line the city is set on, or the mountains surrounding the city that funnels smog into the valley, or the flood plains or the disrupted wildfire corridors, or the human induced environmental change that aggravates the ecosystem and threatens to poison the city if neglect of the human role in environmental degradation continues. No, instead, what is pondered are 'coincidence' and 'eschatology,' the 'real' is not tackled because it is easier to relegate these vicissitudes to chance or 'acts of God'. A separation from responsibility through a proxy God is much easier to cope with, and blame on, than, say, moving a whole city to safer more secure ground or more sustainable living. Furthermore, faith in Christ's impending return causes premillennialists to be interested only in short-term political-theological outcomes, not long-term solutions essential for environmental action.

There are a number of direct political actions that premillennialists use to make their prophecy come true (or at least support its progress). These are most evident when considering the role of lobby groups that seek support for Israel in the American congress, Senate and White House. Examples of such include: The Friends of Israel Gospel Ministry whose periodical Israel My Glory is widely distributed in North America and Israel; 'End-Time Handmaidens' an Arkansas based Pentecostal ministry; the International Fellowship for Christians and Jews; and many Southern Baptist congregations, including Jerry Falwell's ministries, that have publicly targeted Jews for

\footnotetext{
${ }^{26}$ M. Davis, Ecology of Fear: Los Angeles and the Imagination of Disaster (New York: Vintage Books, 1999) p.8.
} 
conversion. $^{27}$ An example with an overt agenda of legislative encouragement is The National Unity Coalition for Israel, which is allegedly comprised of 'approximately forty million Jews and Christians... [and] have determined that they will not merely sit back but will make an impact in America by speaking out for Israel with a unified voice'. ${ }^{28}$ All of these lobby groups are inexorably linked to both the United States and the Israeli governments. The relationship the Bush administration has with the Christian right and the pro-Israel lobby is also reflected through US Attorney General John Ashcroft, Israel's Ambassador to the US Daniel Ayalon, Southern Baptist Convention leader and spiritual advisor to Bush, Richard Land, and Congressman Tom Lantos, all of whom are powerful advocates of Israel's interests in the House.

Jerusalem's Time Elevator, described as 'Israel as IMAX', with seats that move with the picture and baptized mist that falls from the ceiling, is a material example of the theatricality between Israel and Evangelical relations. The Time Elevator was constructed with the intention of attracting American Christians to experience the rise and fall of the four kingdoms of Daniel spanning over 3,000 years of Jerusalem's history. For those who believe in the 'second coming of Jesus', for whom the Time Elevator is targeted, it is hoped they will return to America to 'spread the gospel about the Promised Land' so as to entice further tourism in Israel. ${ }^{29}$ Furthermore, Pat Robertson and Israel's ministry of tourism are working together to develop a $\$ 60$ million 125 acre Jesus Theme Park equipped with a 'Holy Bible Garden', 'Christian Experience Auditorium', 'Multimedia

\footnotetext{
${ }^{27}$ G. Gorenberg, The End of Days: Fundamentalism and the Struggle for the Temple Mount (Oxford: Oxford University Press, 2000) p.166

${ }^{28}$ W. E. Sutter, 'The Zion Connection: Jews and Christians-Common Ground', Israel My Glory, Aug./Sept. (1999), p.14; I found this periodical strategically placed on a bus seat in Ottawa, Ontario.

${ }^{29}$ M. Patriquin, 'Chaim and the Great Time Elevator', The Walrus, Oct. 2006, p.19. For the Time Elevator, go to: www.time-elevator.it. Hitchcock has visited Israel twice and plans to return in June, 2006 (email conversation on March $13^{\text {th }}, 2006$ ).
} 
Center' and a 'Sea of Galilee Amphitheatre'. ${ }^{30}$ More than half of the two million tourists that visit Israel each year are Evangelical Christians. ${ }^{31}$

\section{Without Geography 'They're' Nowhere}

It should be clear that an analysis of premillennial geopolitics is important and has major political implications beyond the premillennialism's disciplinary boundaries. Religion in geopolitics is, however, vastly understudied. Those sparse publications that do arise on the topic are usually oriented to how practical geopoliticians have used religion to justify political action or how certain formal geopoliticians were religiously motivated. This analysis has focused on 'religion as geopolitics', that is, how religions have formulated their own geopolitics albeit often influenced by discursive practices outside religious bounds. And it is for this reason, that there is an entanglement between politics, culture and religion that inform each other in a synergy, that one should consider such constructions relevant to geopolitical scholarship. If we are interested in 'making sense' of geopolitics, we must attend to all of its influencing factors such as how it is affected by religion and, reciprocally, how geopolitics has pervaded religion. It is how geopolitics get blurred between porous boundaries of influence that is paramount to understanding the subject.

Using theatre to unveil the political reasoning strategies Hitchcock uses could be used in further studies of religion or other forms of geopolitics that attempt to transcend the theatrum mundi. Theatre metaphors are tools for removing the 'self' from world stage to the auditorium to analyse and scrutinize the world below. This removal is the practice

\footnotetext{
${ }^{30}$ I. R. Prusher, 'A Theme Park for the Holy Land', Christian Science Monitor. Nov. 10, (2005). [www.csmonitor.com/2005/1110/p06s01-wome.html].

${ }^{31}$ Ibid.
} 
of cartography: to shrink the world into manageable pieces from which to 'graph' the 'geo'. This practice is a necessary precondition of the geopolitician and for this reason theatre is a valuable way to think through and criticize the geopolitical constructions. As removed, partial, transcendent and un-self-reflexive of the world, one has removed themselves from having to engage in the materiality and everyday lives of the people that they incarcerate through geo-graphical generalizations. These terms of analysis could have some application outside the borders of premillennialism and geopolitics, particularly how other cultural forms can be scrutinized though the figure of the stage-a theatrics of culture and the theatrics of politics. The theatre metaphor has a long history in American culture. Richards makes this point but also suggests that, 'theater appears frequently in American writing as a metaphor for history itself, even while such usage reflects the rhetorical history of theater as a trope'. ${ }^{32}$ Therefore, beyond religious analysis, the theatre metaphor can be applied to scholarship on secular topics. Certainly using theatre as a vector for unpacking Hitchcock's geopolitics has proven fruitful for this thesis.

Beyond an analysis of theatre, Hitchcock's authorization also revealed that his work is deeply embedded in masculine sentiments deserving of feminist critique. Prophecy is exclusively a male providence and one could develop a feminist critique of prophecy and authority, particularly in Hitchcock's portrayal of himself, and his escapist strategies, as 'rational', 'thinking', 'cultural', 'ordained' and 'Holy' man set apart from the 'irrational', 'bodily', and 'earthy' woman. This reinforces the premillennialist vertical association between Man and God that defines men as superior to the Earth. However,

${ }^{32}$ J. H. Richards, Theatre Enough: American Culture and the Metaphor of the World Stage, 1607-1789 (Durham: Duke University Press, 1991) pp.xii-xiii. 
feminism is not the focus of this analysis. Suffice it to say, it would be a valuable project but would be a project on its own; one that would bring focus to geopolitical optics and its traditional gendered masculine gaze. ${ }^{33}$

Premillennialist literature itself needs to be reviewed in more detail. Specific case studies that focus on how other religions, sects, and particular views of history have imagined geographies, justified wars, and constrained action are also needed. Further research needs to examine the direct links between explicit actions taken by premillennailists that influence foreign policy, or support initiatives that seemingly fulfill premillennial prophecy. Though this thesis has only analysed the genealogy of the strategies Hitchcock uses, it would be important to see how other popular premillennial authors have attenuated their geopolitics. More than this, and as was written in Chapter 1, research on how other religions have made their own geopolitics and how religion can be seen as an intrinsic part of many geopolitical constructions, whether explicit as in the influence the Jesuit Edmond Walsh had in American foreign policy or other implicit

\footnotetext{
${ }^{33}$ For feminist deconstruction of secular and religious apocalyptic, see L. Quinby, Anti-Apocalypse: Exercises in Genealogical Criticism (Minneapolis: University of Minnesota Press 1994). As an example, David Sweet, Hamilton area MP and former president of Promise Keepers Canada, the Canadian arm of the US-based evangelical Christian organization, said in 2001: 'Men are natural influencers, whether we like it or not. There's a particular reason why Jesus called men only. It's not that women aren't co-participators. It's because Jesus knew women would naturally follow'. D. Sweet, Christian Week, November 27th, 2001 [http://72.14.207.104/u/ChristianWeek?q=cache:XZFwLynLeE8J:christianweek.org/Stories/vol15/no16/sto ry4.htmll. Sweet's comments are an example of interpreting the Bible for political means; one that has direct affects on womens' rights and how women see themselves in society. A young woman at a 'Chosen Women' Rally, a female counterpart to the all-male Promise Keepers, stated: 'Our job is to submit to our teachers and our Professors; even if we know they are wrong. It is then in God's hands'. Again the result, albeit not directly, of such statements Sweet has made reduces history to a masculine historical determinism. This woman's statement can have the result of inadvertently supporting war, in the case of the United States where the 'teacher' (George W. Bush) should not be questioned (See [www.now.org/issues/right/promise/mythfact.html]).
} 
analyses that suggest the American state and Western society in general is grounded in Christian morals and proselytising sentiments. ${ }^{34}$

This thesis has shown that geography, beyond metaphor and description, has the power to create, advance, recreate and misuse international politics and essentially, personal landscapes of people's beliefs. For premillennialists, prophecy is about creating a new, derivative cartography to remake the world in the image of their biblically inspired maps, but it is also about retracing a biblical taxonomy of toponyms to make global politics the geopolitics of their — and only their-God. The Cold War prophetic scenario reinforces the idea that Communists were a biblical evil. Just as true believers have drawn boundaries circumscribing Muslims in the Middle East, most dispensational books on matters of prophecy begin by conflating the prophetic toponyms in the Bible with current nation-states and their roles for the End Times. For millions of people who read these books they become geography textbooks about the world of the 'Other out there'. A 2002 National Geographic-Roper survey found the United States to have the second poorest geographical literacy among 18 to 24 year olds tested from nine countries. ${ }^{35}$ Disturbingly, this may have the effect of encouraging premillennialists, and North Americans in general, to imagine and draw-with the power of perception and pre-conception-a world without objective geographical or historical reference. According to Bauman the success of the Christian Right in American politics and the recent decrease in social assistance programs in the United States, many people have and will turn to evangelical churches for social support with the result of reinforcing the Evangelical/political Right

${ }^{34}$ G. Ó Tuathail, 'Spiritual Geopolitics: Fr. Edmond Walsh and Jesuit Anti-Communism', in K. Dodds and D. Atkinson (eds.), Geopolitical Traditions: A Century of Geopolitical Thought (London: Routledge 2000) pp. $187-210$

35 'Global Geographic Literacy Survey', National Geographic-Roper, (2002) p.17. Mexico came in last and Canada a close third. 
synergy, as a specific mode of national political subjectivity, that is usefully exploited by neoconservative politicians. ${ }^{36}$

Furthermore, the War in/on Iraq has created new xenophobic realities as average Americans ask: 'Are you a terrorist?' As Gregory has explained, ‘war is individualized as every citizen becomes a potential terrorist [or 'bad' Muslim] who has to prove that he or she is not a menace to society [and] becoming Christian is a nationalist act, an act of jingoism.${ }^{37}$ One of the most telling examples of this is the addition of 'under God' to the Pledge of Allegiance in $1951 .^{38}$ An act the US congress passed because of the perception that, "America must be defended by the spiritual values which exist in the hearts and souls of the American people' ${ }^{39}$ As Canipe notes, church attendance in the United States rose from $37 \%$ to $49 \%$ between the years of 1940 to $19555^{40}$ This is important and is foregrounded in Dalby's formulation that 'religious identity was removed from citizenship as a political strategy to reduce the likelihood of warfare by removing the direct temptations to assert identity violently'. ${ }^{41}$ An atavism of Christian identities, then, has obvious advantages for the militarization of the Others' space and also the justifications for making Iraq a battlefield. In security discourse, Bush's use of religious

\footnotetext{
${ }^{36}$ We should remember that in America, with commercial success comes cultural respectability. On religion and social programs, see Z. Bauman, Identity: Conversations with Benedetto Vecchi (Cambridge: Polity, 2004) p.47 and 85-87; See also W. E. Connolly, 'The Evangelical-Capitalist Resonance Machine', Political Theory 33 (2005).

${ }^{37}$ Gregory, The Colonial Present, p.261.

${ }^{38}$ L. Canipe, 'Under God and Anti-Communist: How the Pledge of Allegiance Got Religion In Cold War America', Journal of Church and Society 45/3 (2003) pp.305-323.

${ }^{39}$ Ibid, p.316, emphasis added.

${ }^{40}$ Ibid.

${ }^{41}$ S. Dalby, Environmental Security (Minneapolis: University of Minnesota Press, 2002) p.13. There are, of course, countless examples of how Christianity has mobilized its clout toward peace and cross-cultural acceptance. Many Evangelical groups in the American south like the Sanctuary Movement, for example, help Mexican immigrants cross the US-Mexico border safely, feed them and help find them jobs. See, N. Soguk, 'Transnational/Transborder Bodies: Resistance, Accommodation, and Exile in Refugee and Migration Movements on the US-Mexican Border', in M. J. Shapiro and H. R. Alker (ed.) Challenging Boundaries: Global Flows, Territorial Identities (Minneapolis: University of Minnesota Press, 1996) pp.310-319.
} 
language is not merely a 'nod' to the Christian Right; it tacitly encourages 'undecided' believers to the fold of the premillialists and abjure other beliefs-even if they merelypretend to. ${ }^{42}$ Bush has provided a moral map of reality that fixes itself to identity in ontological terms.

This work is not an attempt to vilify the United States; rather it is exhortation for a more holistic geographical knowledge of the world. It intends to open-up those spaces of social justice that have been foreclosed by reduced social spending. This work is neither an attempt to vilify Christianity. Christianity can be a powerful force for peace and crosscultural acceptance that can be used both as a political and a social tool from which to open up spaces of dialogue and worlds of connection. But premillennialist Christianity can also be used to close off these spaces and can be manipulated to paint a fatalistic and evil character onto the world which may have the result of excluding Others and justifying war.

Religious language and performances can justify geopolitical mappings of the world by attributing Manichean moral qualifications of 'good' and 'bad' to space. Ideas like the coming Rapture teach followers to embrace the destruction of the world and act as channels for legitimating violence. The implications for written constructions of space are not trivial: war kills. As Jill Lepore, writing of King Philip's War (1675-1676) (which to Boston Minister Increase Mather was the Red Horse of the Apocalypse) writes: 'Wounds and words—-the injuries and their interpretations-cannot be separated, that acts of war generate acts of narration, and that both types of acts are often joined in a common purpose: defining the geographical, political, cultural, and sometimes racial and national

\footnotetext{
${ }^{42}$ W. E. Connolly, 'Tocqueville, Territory, and Violence', in M. J. Shapiro and H. Alker (eds.) Challenging Boundaries: Global Flow, Territorial Identities (Minneapolis: University of Minnesota Press, 1996) p. 146.
} 
boundaries between peoples'. ${ }^{43}$ Therefore this form of Apocalyptic geopolitics needs to be subject to critical analysis because of its cultural alienation of Others and its valorization of violence and sacrifice. Moralized geographies as the putative grounding of religious politics must never be taken-for-granted because geography is not the innocent mould of the social world: it has the power to persuade and justify. Religion and space are entwined with their respective meta-relations of knowledge and power. Together they attempt to make unequivocal common sense of the world.

It must be acknowledged that being above the world requires alterity-or discord. ${ }^{44}$ Being of the world also requires alterity but recognizes existence as part of the whole, and not separate from it, and may be capable of a mensch-ideal and egalitarian relations with others, rather than the skandalon ones. Because all humans are implicated and connected to each other in this difference-making process, an obligation to the Other across moral space may be possible if society could comprehend a morally flat and equal world. The Lakota term for this, mitakuye oyasin, meaning 'all are my relatives' or 'we are all related' would be an important break with premillennial superiority and good/bad interpretations of hierarchical identity ${ }^{45}$ In the aptly titled documentary What The Bleep Do We Know?, Miceal Ledwith, an Irish theologian, puts this dualism into question. $\mathrm{He}$ explains that meritocratic security, like Rapture security, for some Christians is entrenched in the idea that:

\footnotetext{
${ }^{43}$ J. Lepore, The Name of War: King Phillip's War and the Origins of American Identity (New York: Alfred A. Knopf, 1998) p.X. On Increase Mather, see S. J. Stein, 'Transatlantic Extensions: Apocalyptic in Early New England', in Patrides and Writtereich, Apocalypse in English Renaissance Thought and Literature, p269-271 quoted from Boyer, When Time Shall Be No More, p.69.

${ }^{\frac{1}{44}}$ See W. E. Connolly, 'Suffering, Justice, and the Politics of Becoming', in D. Campbell and M. J. Shapiro (eds.), Moral Spaces: Rethinking Ethics and World Politics (Minneapolis: University of Minnesota Press 1999) pp.125-153.

${ }^{45}$ M. Beier, 'Beyond Hegemonic State(ments) of Nature', in G. Chowdhry and S. Nair (eds.), Power. Postcolonialism and International Relations (London: Routledge, 2002) p.104.
} 
If I do this, I'm going to get punished by God. If I do the other thing I'm going to get rewarded. This is a really poor description that tries to carve out a path in life for us to follow. But with deplorable results because there is really no such thing as good or bad. We're judging things far too superficially that way. Does that mean you're in favour of sin and licentiousness and depravity? No. It simply means that you need to improve your expression and understanding of what you're dealing with here. There are things that I do, and I know they'll evolve me. There are other things that will not evolve me. But it's not good or bad. There's no God waiting to punish you because you did one or the other. ${ }^{46}$

Certainly this is difficult to imagine when one has these Christian categories creating and directing their ontological existence in Western society. ${ }^{47}$ To transcend this and to topple hierarchical moral spaces in similar terms is not the solution, or even a solution, but rather a debate of alternatives as to how one can see, interpret, and represent the world differently. Christianity has potential to raze the heads of the Beasts of premillennialism and thereby thwart violence, herald peace, and stop war through acceptance of the Other and all their differences. Just as Christianity can influence the state to see the subaltern 'evil' Other, so too can it use that power to stop the state from a perpetual practice of (im)morally reterritorializing the 'enemy' Other.

Hitchcock’s Muslim, Roman, and Russian spaces take on particular meanings (in this case 'evil'), as they are placed into geopolitical categories. However, there are other ways of looking at the world, different from hierarchical moral spaces and inside/outside politics of exclusion. Space could instead be thought of as 'connective'. Amin's conception of 'unbounded spaces' of connection through vectors and nodes is an interesting alternative. Nodes, in this formulation, represent location and vectors connect

\footnotetext{
${ }^{46} \mathrm{M}$. Ledwith in What The Bleep Do We Know? directed by William Arntz (2004).

${ }^{47}$ T. B. Strong, 'Language and Nihilism: Nietzsche's Critique of Epistemology', in M. J. Shapiro (ed.), Politics and Language (New York: New York University Press, 1984).
} 
them resulting in scalar identities. ${ }^{48}$ Social connections are then places without spaces. It is to suggest a world of deterritorialized responsibility in favour of the obligatory. It results in a means whereby all things in the world, religion included can be conceived of as a coeval and flat moral plane of inter-cultural interconnections.

\footnotetext{
${ }^{48}$ A. Amin, 'Regions Unbound: Towards a New Politics of Place', Geografiska Annaler B/86 (2004) pp.3344. For a discussion on spatial connections, 'spatialities of power' and 'fields' of inter-relations, see J. Agnew, 'Mapping Political Power Beyond State Boundaries: Territory, Identity, and Movement in World Politics', Millennium: Journal of International Studies 28/3 (1999) pp.503-507.
} 
Agnew, J., 'The Territorial Trap: The Geographical Assumptions of International Relations Theory', Review of International Political Economy 1/1 (1994) pp.5380 .

Agnew, J., and S. Corbridge, Mastering Space: Hegemony, Territory and International Political Economy (London: Routledge, 1995).

Agnew, J., Geopolitics: Re-visioning World Politics (London: Routledge, 1998).

Agnew, J., 'Mapping Political Power Beyond State Boundaries: Territory, Identity, and Movement in World Politics', Millennium: Journal of International Studies 28/3 (1999) pp. 499-521.

Agnew, J., 'Commentary III: Learning From the War on Iraq', The Arab World Geographer 6/1 (2003). Available at: [http://users.fmg.uva.nl/vmamadouh/awg/forum3/agnew.html].

Allah, A. M. H. F., 'Islam and Violence in Political Reality', Middle East Insight. 4/4-5 (1986) pp.4-13.

Amin, A., 'Regions Unbound: Towards a New Politics of Place', Geografiska Annaler B/86 (2004) pp.33-44.

Appleby, R. S., 'Fundamentalism and Nationalist Religious Movements', in J. Agnew, K. Mitchell and G. Ó Tuathail (eds.) A Companion to Political Geography (Malden, MA: Blackwell, 2003) pp.378-392.

Asad, T., Formulations of the Secular: Christianity, Islam, Modernity (Stanford: Stanford University Press, 2003).

Barkun, M., 'The Language of Apocalypse: Premillennialists and Nuclear War', in M. W. Fishwick and R.E. Browne, (eds.), The God Pumpers: Religion in the Electronic Age (Bowling Green OH: Bowling Green State University Press, 1987) pp.159173.

Barnes, T. and J. Duncan, (eds.) 'Introduction: Writing Worlds', in Writing Worlds: Discourse, Text and Metaphor in the Representation of Landscape (London: Routledge, 1992) pp.1-12. 
Bater, B. R., 'Apocalyptic Religion in Christian Fundamentalism', in M. Wallace and T. H. Smith (eds.), Curing Violence (Sonoma, CA: Polebridge Press, 1994) pp.287304.

Bauman, Z., Identity: Conversations with Benedetto Vecchi (Cambridge: Polity, 2004).

Beardsworth, R., Derrida and the Political (London: Routledge, 1996).

Beier, M., 'Beyond Hegemonic State(ments) of Nature', in G. Chowdhry and S. Nair (eds.), Power, Postcolonialism and International Relations (London: Routledge, 2002) pp.82-114.

Beller, J. L., 'Capital/Cinema', in E. Kaufman and K. J. Heller (ed) Deleuze and Guattari: New Mappings in Politics, Philosophy, and Culture (Minneapolis: University of Minnesota Press, 1998) p.77-95.

Bercovitch, S., The American Jeremiad (Madison: University of Wisconsin Press, 1978).

Bessis, S., Western Supremacy: Triumph of an Idea?, Patrick Camiller (trans.) (New York: Zed Books, 2003).

Blumenthal, S., 'In Bush We Trust', Salon.com March 23 (2006).

[www.salon.com/opinion/blumenthal/2006/03/23/bush_terror/index_np.html].

Borchardt, F. L., Doomsday Speculation as a Strategy of Persuasion: A Study of Apocalypticism as Rhetoric (Lewiston: The Edwin Mellon Press, 1990).

Boyer, P., When Time Shall Be No More: Prophecy Belief in Modern American Culture (Cambridge, Mass: Harvard University Press, 1992).

Broadway, B., 'Direst of Predictions For War in Iraq: End-Time Interpreters See Biblical Prophecies Being Fulfilled', The Washington Post (March 8, 2003) p.B09.

Brown, P., Augustine of Hippo: A Biography (Berkeley: University of California Press, 1969).

Brummett, B., Contemporary Apocalyptic Rhetoric (New York: Praeger, 1991).

Burke, K., 'The Rhetoric of Hitler's "Battle", in M. J. Shapiro (eds.) Politics and Language (New York: New York University Press, 1984).

Butler, J., Gender Trouble: Feminism and the Subversion of Identity (New York: Routledge, 1990). 
Calvin, J., Commentary on a Harmony of the Evangelists, Matthew, Mark, and Luke (Grand Rapids: Baker Book House, no date).

Campbell, D., 'Political Prosaics, Transversal Politics, and the Anarchical World', in M. J. Shapiro and H. Alker (eds.), Challenging Boundaries: Global Flow, Territorial Identities (Minneapolis: University of Minnesota Press, 1996) pp.7-32.

Campbell, D., Writing Security: United States Foreign Policy and the Politics of Identity (Minneapolis: University of Minnesota Press, 1998 [Originally published in 1992]).

Canipe, L., 'Under God and Anti-Communist: How the Pledge of Allegiance Got Religion In Cold War America', Journal of Church and Society 45/3 (2003) pp.305-323.

Caputo, J. D., The Prayers and Tears of Jacque Derrida: Religion without Religion (Bloomington: Indiana University Press, 1997).

Carrette, J., Michel Foucault: Religion and Culture (New York: Routledge, 1999).

Case, S. J., The Millennial Hope: A Phase of War-Time Thinking (Chicago: University of Chicago Press, 1918).

Cohn, N., The Pursuit of the Millennium: Revolutionary Millenarians and Mystical Antichrists of the Middle Ages (London: Temple Smith, 1970 [Originally published in 1957]).

Coleman, M., 'The Naming of 'Terrorism' and Evil 'Outlaws': Geopolitical Placemaking After 11 September', Geopolitics 8/3 (2003) pp.91-93.

Collins, J. J., The Apocalyptic Imagination: An Introduction to Jewish Apocalyptic Literature (Grand Rapids, MI: Wm. B. Eerdmans, 1998).

Connolly, W. E., 'Tocqueville, Territory, and Violence', in M. J. Shapiro and H. Alker (eds.) Challenging Boundaries: Global Flow, Territorial Identities (Minneapolis: University of Minnesota Press, 1996) pp.141-164.

Connolly, W. E., 'Suffering, Justice, and the Politics of Becoming', in D. Campbell and M. J. Shapiro (eds.), Moral Spaces: Rethinking Ethics and World Politics (Minneapolis: University of Minnesota Press, 1999) pp.125-153.

Connolly, W. E., 'The Evangelical-Capitalist Resonance Machine', Political Theory 33 (2005) pp.869-886.

Cox, R., 'Social Forces, States and World Orders' in R. Keohane (ed.) Neorealism and Its Critics, (New York: Columbia University Press, 1986). 
Curry-Roper, J. M., 'Contemporary Christian Eschatologies and Their Relation to Environmental Stewardship', Professional Geographer 42/2 (1990) pp.157-165.

Dalby, S., 'Geopolitical Discourse: The Soviet Union as Other', Alternatives: Social Transformation and Humane Governance 13/4 (1988) pp.415-42.

Dalby, S., Creating the Second Cold War (New York: Guilford, 1990).

Dalby, S., 'Critical Geopolitics: Discourse, Difference, and Dissent', Environment and Planning D: Society and Space 9 (1991) pp.261-283.

Dalby, S., and G. Ó Tuathail, 'The Critical Geopolitics Constellation: Problematzing Fusions of Geographical Knowledge and Power', Political Geography. 15/6-7 (1996) pp.451-456.

Dalby, S., 'Writing Critical Geopolitics: Campbell, Ó Tuathail, Reynolds, and Dissident Scepticism', Political Geography. 15/6-7 (1996) pp.655-660.

Dalby, S., Environmental Security (Minneapolis: University of Minnesota Press, 2002).

Davis, M., Ecology of Fear: Los Angeles and the Imagination of Disaster (New York: Vintage Books, 1999).

Davis, M., Dead Cities: And Other Tales (New York: The New Press, 2002).

Debrix, F., 'Tabloid Realism and the Revival of American Security Culture', Geopolitics 8/3 (2003) pp.151-190.

De Certeau, M., The Practice of Everyday Life (Berkley: University of Califonia, 1984).

De Larrinaga, M., Alterity, Social Order, and the Meaning(s) to Security (Unpublished $\mathrm{PhD}$ dissertation, University of Ottawa, 2002).

Deleuze, G., Cinema 1: The Movement-Image. H. Tomlinson and B. Habberjam (trans) (Minneapolis: University of Minnesota Press, 1986).

Deleuze, G. and F. Guattari, A Thousand Plateaus. B. Massumi (trans) (Minneapolis: University of Minnesota Press, 1987).

Deleuze, G., Cinema 2: The Time-Image. H. Tomlinson and R. Galeta (trans) (Minneapolis: University of Minnesota Press, 1989).

Dijkink, G., 'When Geopolitics and Religion Fuse', presented at the $\underline{5^{\text {th }} \text { Pan-European }}$ International Relations Conference, in The Hague (Sept. 2004). 
Diken, B., and C. B. Laustsen, '7-11, 9-11, and Postpolitics', Alternatives 29/1 (2004) pp.89-113.

Dodds, K., and J. Sidaway, 'Locating Critical Geopolitics', Environment and Planning D: Society and Space. 12 (1994) pp.515-524.

Dodds, K., 'Political Geography III: critical geopolitics after ten years', Progress in Human Geography. 25/3 (2001) pp.469-484.

Dubose, L., and J. Reid, The Hammer: Tom Delay, God, Money, and the Rise of the Republican (New York: PublicAffairs, 2004).

Dyer, C. H., The Rise of Babylon: Is Iraq at the Center of the Final Drama? (Chicago: Moody Publishers, 2003 [Originally published in 1991]).

Eliade, M., The Sacred and the Profane: The Nature of Religion (New York: Hardcourt, 1987 [Originally published in 1957]).

Evans, M., Jerusalem Betrayed: Ancient Prophecy and Modern Conspiracy Collide in the Holy City (Dallas: Word Publishing, 1997).

Foucault, M., 'A Preface to Transgression' in D. Bouchard (eds.) Language, CounterMemory, Practice D. Bouchard and S. Simon (trans.) (Ithaca: Cornell University Press, 1977) pp.29-52.

Foucault, M., 'The Subject and Power', in H. Dreyfus and P. Rainbow (eds.), Michel Foucault: Beyond Structuralism and Hermeneutics (Brighton: Harvester, 1982) pp.208-226.

Gallaher, C., 'Identity Politics and the Religious Right: Hiding Hate in the Landscape', Antipode 9/3 (1997) pp.256-277.

Gallaher, C., 'The Religious Right Reacts to Globalization', in M. A. Tetreault and R. A. Denemark (eds.), Gods, Guns, and Globalization: Religious Radicalism and International Political Economy (Boulder: Lynne Rienner, 2004) pp.31-56.

Gallup, G. Jr. and J. Castelli, The People's Religion: American Faith in the Nineties (New York: Macmillian Publishing, 1989).

George, J., 'Understanding International Relations after the Cold War: Probing Beyond the Realist Legacy', in M. J. Shapiro and H. Alker (eds.) Challenging Boundaries: Global Flow, Territorial Identities (Minneapolis: University of Minnesota Press, 1996) pp.33-82.

Gesenius, W., Gesenius' Hebrew and Chaldee Lexicon. Samuel Tregelles (trans.) (Grand Rapids, MI: Wm. B. Eerdmans, 1949). 
Girard, R., 'Generative Scapegoating', in R. H. Kelly (ed.), Violent Origins (Stanford: Stanford University, 1987) pp.95-103.

Giroux, H. A., 'Beyond Belief: Religious Fundamentalism and Cultural Politics in the Age of George W. Bush', Cultural Studies/Critical Methodologies. 4/4 (2004) pp.415-426.

'Global Geographic Literacy Survey', National Geographic-Roper, (2002).

Gorenberg, G., The End of Days: Fundimentalism and the Struggle for the Temple Mount (Oxford: Oxford University Press, 2000).

Gorham, E. B., The Theatre of Politics: Hannah Arendt, Political Science and Higher Education (Lanham, MD: Lexington Books, 2000).

Graham, S., 'Vertical Geopolitics: Baghdad and After' Antipode 36/1 (2003) pp.12-23.

Gregory, D., Geographical Imaginations (Oxford: Blackwell, 1994).

Gregory, D., The Colonial Present: Afghanistan, Palestine, Iraq (Malden, MA: Blackwell, 2004).

Gregson, N., and G. Rose. 'Taking Butler Elsewhere: Performativities, Spatialities and Subjectivities', Environment and Planning D: Society and Space 24/4 (2000) pp.433-453.

Halsell, G., Prophecy and Politics: Militant Evangelists on the Road to Nuclear War (Westport, CN: Lawrence Hill \& Co., 1986).

Hanegraaff, H. and S. Brouwer, The Last Disciple (Wheaton, Ill: Tyndale, 2004).

Haraway, D. J., Simians, Cyborgs and Women: The Reinvention of Nature (London: Routledge, 1992).

Harley, J. B., 'Deconstructing the Map', in T. Barnes and J. Duncan (eds.) Writing Worlds: Discourse, Text and Metaphor in the Representation of Landscape, (London: Routledge, 1992) pp.231-247.

Harvey, D., The New Imperialism (New York: Oxford, 2003).

Hatch, N.O., The Democratization of American Religion (New Haven: Yale University Press, 1989).

Hatzopoulous, P. and P. Petito (eds.), Religion in International Relations: The Return from Exile (New York: Palgrave Macmillan, 2003). 
Hill, C., Antichrist in Seventeenth-Century England (London: Oxford University Press, 1971).

Hitchcock, M., The Silver Kingdom: Iran is History and Prophecy (Oklahoma City: Hearthstone Publishing, 1993).

Hitchcock, M., After the Empire: Bible Prophecy in Light of the Fall of the Soviet Union (Wheaton, Ill: Tyndale House, 1994).

Hitchcock, M., 101 Answers To the Most Asked Questions About the End Times (Sisters, OR: Multnomah, 2001).

Hitchcock, M., What on Earth is Going On? (Sisters, OR: Multnomah, 2002).

Hitchcock, M., The Coming Islamic Invasion of Israel (Sisters, OR: Multnomah, 2002).

Hitchcock, M., Is America in Bible Prophecy? (Sisters, OR: Multnomah, 2003).

Hitchcock, M., The Second Coming of Babylon (Sisters, Ore.: Multnomah Publishers, 2003).

Hitchcock, M., What Jesus Says About the Earth's Final Days (Sisters, Ore.: Multnomah Publishers, 2003).

Hitchcock, M., 'Alignment of the Nations: The Nations of Prophecy Are In the News, But How Do They Align With Scripture?', Interpreting the Signs. Jan. (2003).

Hitchcock, M., 'Alignment of the Nations: The Nations of Prophecy are in the News, but How do they Align with Scripture?', Interpreting the Signs. Jan. (2003).

Hitchcock, M., 'President of Europe: An Update on the Movement Toward Political and Economic Union in Europe', Interpreting the Signs. Jan. (2003).

Hitchcock, M., 'President of Europe: An Update on the Movement Toward Political and Economic Union in Europe', Interpreting the Signs. Jan. (2003).

Hitchcock, M., 'Europe Appeasement, Antisemitism and the Move Toward Unification', Interpreting the Signs. Jan. (2004).

Hitchcock, M., 'EU Signing Ceremony The Latest Event in the Reconstitution of the Roman Empire', Interpreting the Signs. Nov. (2004).

Hitchcock, M., The Truth Behind Left Behind (Wheaton, Ill: Tyndale, 2004). 
Holloway, J. and O. Valins. 'Editorial: Placing Religion and Spirituality in Geography', Social and Cultural Geography 3/1 (2002) pp.5-9.

Hopewell, D., Christian Fundamentalism: A Journey into the Heart of Darkness (Parsippany, NJ: American Atheist Press, 1998).

Howarth, D., Discourse (Buckingham: Open University Press, 2000).

Huntington, S., The Clash of Civilizations and the Remaking of World Order (New York: Touchstone, 1996).

Impe, J. V., 11:59 and Counting (Nashville, TN: T. Nelson, 1987).

Impe, J. V., The Great Escape (Nashville, TN.: Word, 1998).

Jameson, F., Brecht and Method (New York: Verso, 2000).

Jay, M., Downcast Eyes (Berkeley: University of California Press, 1993).

Kaufman, E. and K. J. Heller, Deleuze and Guattari: New Mappings in Politics, Philosophy, and Culture (Minneapolis: University of Minnesota Press, 1998).

Kennan, G. F., 'The Sources of Soviet Conduct', Foreign Affairs 25/4 (1947) pp.566-582.

Kirby, D., (eds.), Religion and the Cold War (Basingstoke: Palgrave-Macmillan, 2003).

Koester, C., Revelation and the End of All Things (Grand Rapids, Mich.: Wm. B. Eerdmans Publishing, 2001).

Kong, L., 'Mapping "New" Geographies of Religion: Politics and Poetics in Modernity', Progress in Human Geography 25/2 (2001) pp.211-233.

Kubiak, A., Agitated States: Performance in the American Theater of Cruelty (Ann Arbor: The University of Michigan Press, 2002).

Lacan, J., The Four Fundamental Concepts of Psycho-Analysis, J. A. Miller (eds.), A. Sheridan (trans.) (London: Penguin, 1979).

LaHaye, T., The Beginning of the End (Wheaton, IL: Tyndale, 1972).

LaHaye, T. and J. B. Jenkins, Left Behind: A Novel of Earth's Last Days (Wheaton, IL: Tyndale, 1995).

LaHaye, T. and J. B. Jenkins, Glorious Appearing (Wheaton, Il.: Tyndale, 2004). 
Lakoff, G., 'Our Moral Values', The Nation (2004)

[http://www.thenation.com/doc.mhtml?i=20041206\&s=lakoff].

Lampton, J., 'The End of the World', Christian Science Monitor. Feb. 18, (2004).

Lefebvre, H., The Production of Space (Oxford: Blackwell, 1991).

Leggett, J., The Carbon War: Global Warming and the End of the Oil Era (New York: Routledge, 2001).

Lepore, J., The Name of War: King Phillip's War and the Origins of American Identity (New York: Alfred A. Knopf, 1998).

Levinas, E., Ethics and Infinity: Conversations with Philippe, N. R. Cohen (trans.) (Pittsburgh: Duquesne University Press, 1985).

Ley, D., and M. Samuels, 'Introduction: Contexts of Modern Humanism in Geography', in D. Ley and M. Samuels (eds.) Humanistic Geography (Chicago: Maroufa, 1978).

Lieven, A., American Right or Wrong: An Anatomy of American Nationalism (New York: Oxford University Press, 2004).

Lindsey, H., The Late Great Planet Earth (Grand Rapids, MI: Zondervan Books, 1970).

Lindsey, H., The 1980's: Countdown to Armageddon (King of Prussia, PA: Westgate, 1980).

Lindsey, H., The Everlasting Hatred: The Roots of Jihad (Murrieta, CA: Oracle, 2002).

Logsdon, S. F., Is the U.S.A. In Prophecy? (Grand Rapids, MI.: Zondervan, 1965).

Lyons, G., 'The Apocalypse will be Televised: Armageddon in an Age of Entertainment', Harper's Magazine, Nov. (2004).

Mackinder, H., 'The Geographical Pivot of History', The Geographical Journal 170/4 (2004 [Originally published in 1904]) pp.298-321.

Mamdani, M., Good Muslim, Bad Muslim: America, the Cold War and the Roots of Terror (New York: Pantheon Books, 2004).

Marsden, G. M., (eds.) 'Evangelicals, History and Modernity', in Evangelicalism and Modern America (Grand Rapids: Wm. B. Eerdmans, 1984) pp.94-102. 
McGinn, B., Apocalyptic Spirituality: Treatises and Letters of Lacantius, Adso of Montier-en-Der, Joachim of Fiore, the Franciscan Spirituals, Savonarola (London: Paulist Press, 1979).

McKenna, T., The Archaic Revival (San Francisco: Harper, 1991).

Megoran, N., 'Christianity and Political Geography: On Faith and Geopolitical Imagination', The Brandywine Review of Faith and International Affairs, 2/2 (2004) pp.40-46.

Miller,_P., The New England Mind: From Colony to Province (Cambridge: Harvard University Press, 1953).

Mills, C. W., 'Situated Actions and Vocabularies of Motive', in M. J. Shapiro (eds.) Politics and Language (New York: New York University Press, 1984).

Mojtabai, A. G., Blessed Assurance: At Home With the Bomb in Amarillo, Texas (Syracuse: Syracuse University Press, 1997).

More, T., Utopia (Mineola, NY: Dover, 1997).

Morris, W., News from Nowhere and Other Stories Clive Wilmer (ed.) (New York: Penguin, 1998) pp.41-231.

Nash, C., 'Progress Reports, Performativity in Practice: Some Recent Work in Cultural Geography', Progress in Human Geography 24/4 (2000) pp.653-664.

Nietzsche, F., Ecce Homo. R. J. Hollingdale (trans) (London: Penguin, 1979 [Originally published in 1888]).

Nietzsche, F., 'The Antichrist', in W. Kaufman (ed) The Portable Nietzsche (London: Penguin, 1982 [Originally published in 1895]) pp.565-658.

Nietzsche, F., Human, All Too Human. Marion Faber (Trans.) (Lincoln: University of Nebraska Press, 1996 [Originally published in 1878]).

New American Standard Bible (NAS) (Anaheim, California: Foundation Publications, 1995).

Newport, F., 'Who Are the Evangelicals?', Gallup News Service, June 24, (2005)

[http://www.gallup.com/poll/content/default.aspx?ci=1690\&pg=1].

Northcott, M., An Angel Directs the Storm: Apocalyptic Religion and American Empire (London: I.B. Tauris, 2004). 
Nyroos, L., 'Religeopolitics: Dissent Geopolitics and the "Fundamentalism" of Hamas and Kach', Geopolitics 6/3 (2001) pp.135-157.

Olsson, G., 'Placing the Holy', in T. Mels (eds.) Reanimating Places: A Geography of Rhythms (Burlington, VT: Ashgate, 2004) pp.201-214.

Osiander, A., 'Religion and Politics in Western Civilization: The Ancient World as Matrix and Mirror of the Modern', Millennium: Journal of International Studies 29/3 (2000) pp.761-790.

Ó Tuathail, G., and J. Agnew, 'Geopolitics and Discourse: Practical Geopolitical Reasoning in American Foreign Policy', Political Geography. 11/2 (1992) pp.190204.

Ó Tuathail, G., and S. Dalby 'Critical Geopolitics: Unfolding Spaces for Thought in Geography and Global Politics', Environment and Planning D: Society and Space. 12 (1994) pp.513-514.

Ó Tuathail, G., Critical Geopolitics: The Politics of Writing Global Space (Minneapolis: University of Minnesota Press, 1996).

Ó Tuathail, G., 'The Patterned Mess of History and the Writing of Critical Geopolitics: A Response to Dalby', Political Geography 15/6-7 (1996) pp.661-665.

Ó Tuathail, G. and S. Dalby, 'Introduction: Rethinking Geopolitics: Towards A Critical Geopolitics’, G. Ó Tuathail and S. Simon Dalby (ed.) Rethinking Geopolitics (London: Routledge, 1998) pp.1-15.

Ó Tuathail, G., 'Spiritual Geopolitics: Fr. Edmond Walsh and Jesuit Anti-Communism', in K. Dodds and D. Atkinson (eds.), Geopolitical Traditions: A Century of Geopolitical Thought (London: Routledge, 2000) pp.187-210.

Park, C., Sacred Worlds: An Introduction to Geography and Religion (New York: Routledge, 1994).

Patai, R., The Arab Mind Revised Edition (New York: Hatherleigh Press, 2002).

Patriquin, M., 'Chaim and the Great Time Elevator', The Walrus, Oct. (2006) pp.15-19.

Pettman, D., After the Orgy: Towards a Politics of Exhaustion (Albany: State University of New York Press, 2002).

Philips, K., American Theocracy: The Peril and Politics of Radical Religion, Oil, and Borrowed Money in the 21st Century (New York: Viking, 2006). 
Phillips, J., The Reformation of Images: Destruction of Art in England, 1535-1660 (Berkeley: University of California Press, 1973).

Phillips, L., and M. Jorgenson, Discourse Analysis as Theory and Method (London: Sage, 2002).

Pile, S., 'Introduction: Opposition, Political Identities and Spaces of Resistance', in S. Pile and M. Keith (eds.) Geographies of Resistance (London: Routledge, 1997) pp.1-32.

Popke, E. J., 'Poststructuralist Ethics: Subjectivity, Responsibility and the Space of Community', Progress in Human Geography 27/3 (2003) pp.298-316.

Prorok, C.and M. Ferber, (ed.), Doing Geographies of Religion (Thousand Oaks, CA: Sage, forthcoming in 2007).

Prusher, I. R., 'A Theme Park for the Holy Land', Christian Science Monitor. Nov. 10, (2005) [www.csmonitor.com/2005/1110/p06s01-wome.html].

Quinby, L., Anti-Apocalypse: Exercises in Genealogical Criticism (Minneapolis: University of Minnesota Press, 1994).

Reeves, M., The Influence of Prophecy in the Later Middle Ages: A Study of Joachimism (London: Oxford University Press, 1969).

Relph, E., 'Post-modern Geographies', Canadian Geographer 35/1 (1991) pp.98-105.

Richards, J. H., Theatre Enough: American Culture and the Metaphor of the World Stage, 1607-1789 (Durham: Duke University Press, 1991).

Ring, L., Divine Kin: Exploring the Special Relationship Between the United States and the State of Israel (Unpublished Major paper, International Affairs, Carleton University, 1997).

Robbins, J. W., 'The Sin of Signing Ecumenical Declarations', The Trinity Foundation. (2000) [http://www.trinityfoundation.org/journal.php?id=130].

Rose, M., 'Reembracing Metaphysics', Environment and Planning A 36/3 (2004) pp.461468.

Said, E., Orientalism (New York: Vintage, 1979).

Salih S. (ed), The Judith Butler Reader (Malden, MA: Blackwell, 2004). 
Scherer, G., 'The Godly Must be Crazy: Christian-Right Views Are Swaying Politicians and Threatening the Environment', Grist Magazine, Oct. (2004) [http://www.grist.org/news/maindish/2004/10/27/scherer-christian/].

Scofield, C. I., (eds.) The Holy Bible, King James Version (KJV) (Korea: Oxford University Press 1996 [originally published in 1901]).

Sells, M. A., The Bridge Betrayed: Religions and Genocide in Bosnia (Berkeley, CA: University of California Press, 1996).

Shapiro, M. J., 'Introduction', in M. J. Shapiro and H. Alker (eds.) Challenging Boundaries: Global Flow, Territorial Identities (Minneapolis: University of Minnesota Press, 1996) pp.xv-xxiii.

Shapiro, M. J., Violent Cartographies: Mapping Cultures of War (Minneapolis: University of Minnesota Press, 1997).

Sharp, J., 'Re-maculinizing Geopolitics? Comments on Gearóid Ó Tuathail's Critical Geopolitics', Political Geography 19/3 (2000) pp.361-364.

Sharp, J., Condensing the Cold War: Reader's Digest and American Identity (Minneapolis: University of Minnesota Press, 2000).

Sidaway, J. D., 'Geopolitics, Geography, and 'Terrorism' in the Middle East', Environment and Planning D: Society and Space 12/3 (1994) pp.357-372.

Soguk, N., 'Transnational/Transborder Bodies: Resistance, Accommodation, and Exile in Refugee and Migration Movements on the US-Mexican Border', in M. J. Shapiro and H. R. Alker (ed.) Challenging Boundaries: Global Flows, Territorial Identities (Minneapolis: University of Minnesota Press, 1996) pp.285-326.

Sparke, M., 'Outsides Inside Patriotism: The Oklahoma Bombing and the Displacement of Heartland Geopolitics', in G. Ó Tuathail and S. Dalby (eds.), Rethinking Geopolitics (London: Routledge, 1998) pp.198-223.

Sparke, M., In the Space of Theory: Postfoundational Geographies of the Nation-State (Minneapolis: University of Minnesota Press, 2005).

Stein, S. J., 'Transatlantic Extensions: Apocalyptic in Early New England', in Patrides and Writtereich, Apocalypse in English Renaissance Thought and Literature (Ithaca, Cornell University Press, 1984) p266-279.

Stoddard, R. and C. Prorok 'Geography of Religion and Belief Systems', in G. Gaile and C. Willmont (eds.) Geography at the Dawn of the $21^{\text {st }}$ Century (Oxford University Press: New York, 2004) pp.760-777. 
Strong, T. B., 'Language and Nihilism: Nietzsche's Critique of Epistemology', in M. J. Shapiro (ed.), Politics and Language (New York: New York University Press, 1984).

Stump, R. W., Boundaries of Faith: Geographical Perspectives on Religious Fundamentalism (Lanham, MD: Rowman and Littlefield, 2000).

Sturm, T. 'Prophetic Eyes: The Theatricality of Mark Hitchcock's Premillennial Geopolitics', Geopolitics. 11/2 (2006) (in press).

Sutter, W. E., 'The Zion Connection: Jews and Christians-Common Ground', Israel My Glory, Aug./Sept. (1999).

Sweet, D., Christian Week, Nov. 27, (2001).

[http://72.14.207.104/u/ChristianWeek?q=cache:XZFwLynLeE8J:christianweek.o rg/Stories/vol15/no16/story4.html].

Taylor, P., Political Geography: World-Economy Nation-State and Locality (Essex: Longman, 1985).

Taylor, P. J., 'Tribulations of Transition', Professional Geographer 44/1 (1992) pp.10-13.

The Holy Bible, New International Version (NIV) (Grand Rapids, MI, Zondervan, 1984).

The Holy Bible, New Living Translation (NLT) (Wheaton, Ill: Tyndale, 1996).

Thompson, L., 'Mapping the Apocalyptic World', in J. Scott and P. Simpson-Housley (eds.), Sacred Places and Profane Spaces: Essays in the Geographics of Judaism, Christianity, and Islam (New York: Greenwood Press, 1991) pp.115-130.

Todorov, T., The Conquest of America: The Question of the Other. R. Howard (trans.). (New York: Harper \& Row, 1984).

Wager, W. W., Terminal Visions: The Literature of Last Things (Bloomington: Indiana University Press, 1982).

Wallace, I., 'Territory, Typology, Theology: Geopolitics and the Christian Scriptures', Geopolitics, 11/2 (2006) (in press).

Walvoord, J. F., The Millennial Kingdom (Grand Rapids: Zondervan, 1959).

Walvoord, J. F., Israel in Prophecy (Grand Rapids: Zondervan, 1967).

Walvoord, J. F., Armageddon: Oil and the Middle East Crisis (Grand Rapids, MI:

Zondervan, 1974). 
Walvoord, J. F., The Nations, Israel, and the Church in Prophecy (Grand Rapids, MI: Zondervan Publishing, 1988).

Weber, T. P., Living in the Shadow of the Second Coming: American Premillennialism, 1875-1925 (New York: Oxford University Press, 1979).

Weber, T. P., On the Road to Armageddon: How Evangelicals Became Israel's Best Friend (Grand Rapids, MI: Baker Academic, 2004).

Wertheim, M., The Pearly Gates of Cyberspace: A History of Space from Dante to the Internet (New York: W. W. Norton 1999).

Wuest, K. Prophetic Light in the Present Darkness (Grand Rapids, MI: Wm. B. Eerdmans, 1955).

Wilson, D., Armageddon Now! The Premillennial Response to Russia and Israel Since 1917 (Grand Rapids, MI: Baker, 1977).

Wolf, E., Europe and the People Without History (New York: Columbia University Press, 1982).

Woodward, D., 'Medieval Mappaemundi', in . J. B. Harley and D. Woodward (eds.) The History of Cartography, Volume 1 (Chicago: University of Chicago Press, 1987) pp.286-370.

Zizek, S., Welcome to the Desert of the Real (London: Verso, 2002). 